UNIVERSIDADE DE SÃO PAULO INSTITUTO DE GEOCIENCIAS

\title{
AVALIAÇÃO DA CONTAMINAÇÃO E DO RISCO ASSOCIADO EM ÁREA DE INDÚSTRIA E SUAS ADJACÊNCIAS, EM COTIA - SP
}

Eurélio Toso Júnior

Orientador: Prof. Dr. Alberto Pacheco

DISSERTAÇÃO DE MESTRADO

Programa de Pós-Graduação em Recursos Minerais e Hidrogeologia

SÃo PAULO

2001 


\section{UNIVERSIDADE DE SÃO PAULO \\ INSTITUTO DE GEOCIENCIAS}

\section{AVALIAÇÃO DA CONTAMINAÇÃO E DO RISCO ASSOCIADO EM ÁREA DE INDÚSTRIA E SUAS ADJACÊNCIAS, EM COTIA - SP}

\section{EURÉLIO TOSO JÚNIOR}

Orientador: Dr. Alberto Pacheco

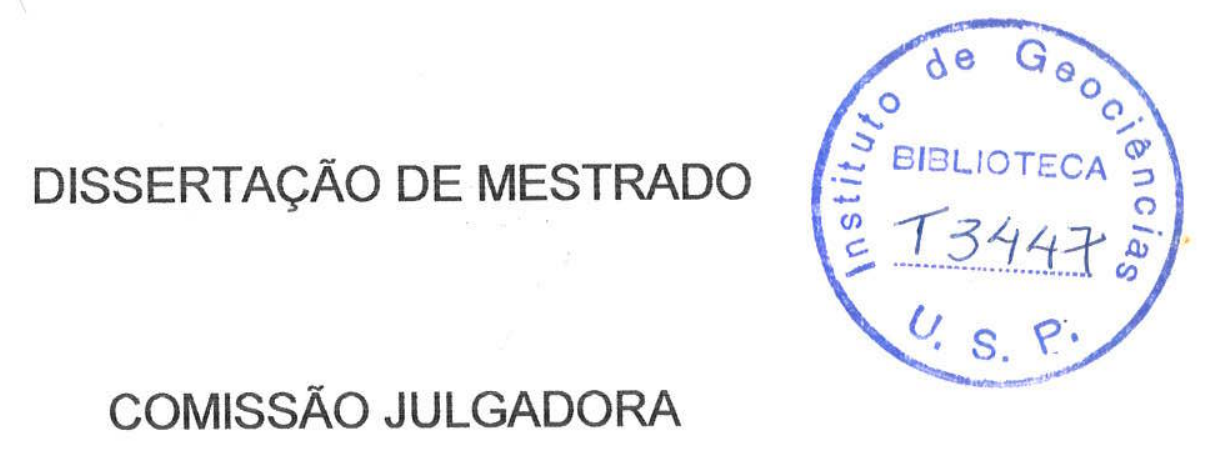

Nome

Presidente: Prof. Dr. Alberto Pacheco

Examinadores: Prof. Dr. Joel Barbujiani Sígolo

Prof. Dr. Luís Enrique Sanchez

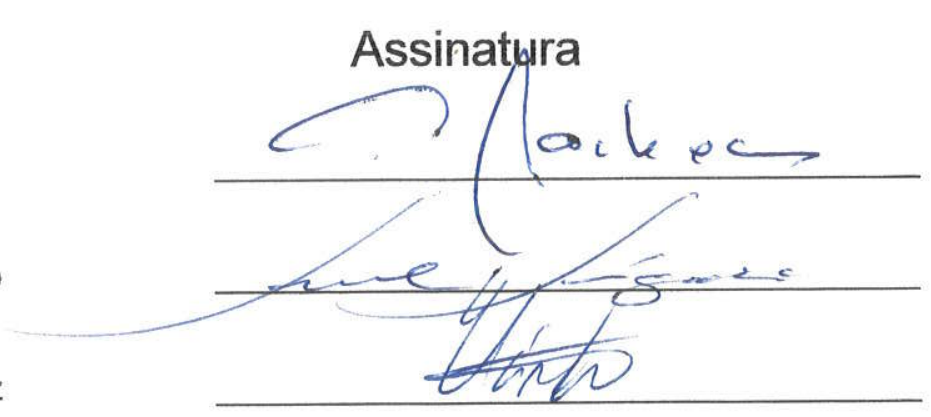

SÃO PAULO

2001 


\section{UNIVERSIDADE DE SÃO PAULO INSTITUTO DE GEOCIENNCIAS}

\section{AVALIAÇÃO DA CONTAMINAÇÃO E DO RISCO ASSOCIADO EM ÁREA DE INDÚSTRIA E SUAS ADJACÊNCIAS, EM COTIA - SP}

Eurélio Toso Júnior

Orientador: Prof. Dr. Alberto Pacheco

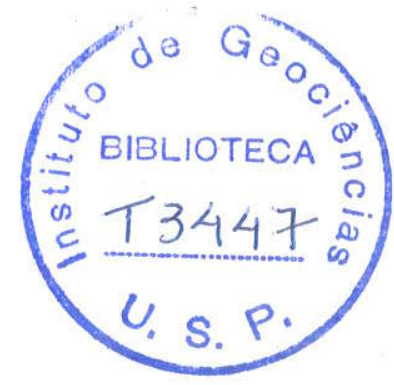

DISSERTAÇÃO DE MESTRADO

Programa de Pós-Graduação em Recursos Minerais e Hidrogeologia

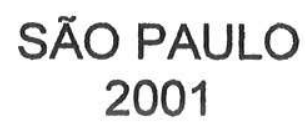

DEDALUS - Acervo - IGC

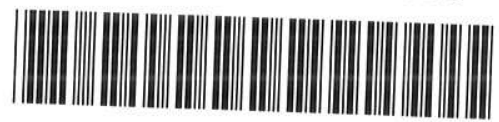

30900008512 


\section{Toso Júnior, Eurélio}

Avaliação da Contaminação e do Risco Associado em Área de Indústria e suas Adjacências, em Cotia, SP / Eurélio Toso Júnior.-São Paulo, 2001.

130 p.: il.

Dissertação (Mestrado): IGc/USP

Orient.: Pacheco, Alberto

1. Avaliação. 2. Hidrogeologia. 3. Contaminação. 4. Risco. 5. Cotia (SP). I. Título

DOACAOSECANO DE

PÚS-GRADUACEAO

Data:26/.11/.01 
A

Giordano e Gianluca

Tereza Meus Pais Bisa e Caboclo 


\section{SUMÁRIO}

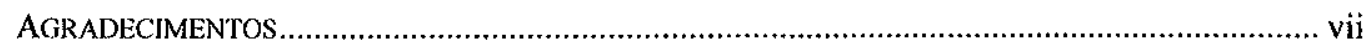

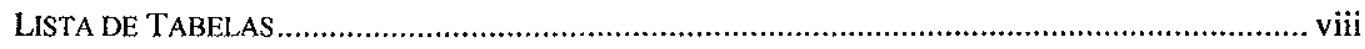

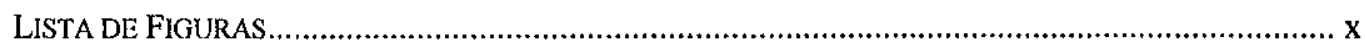

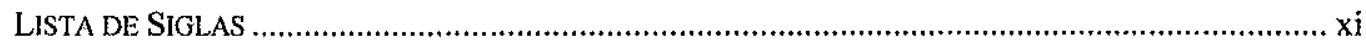

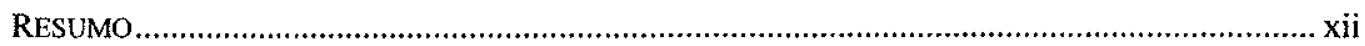

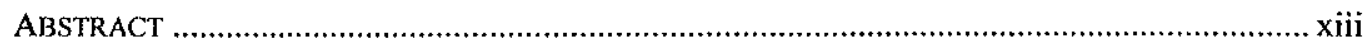

1 INTRODUÇÃ

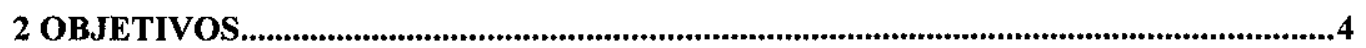

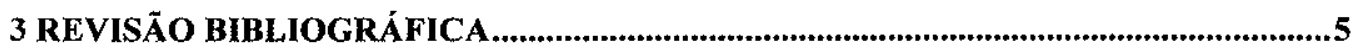

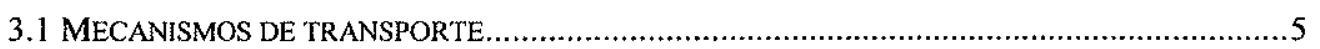

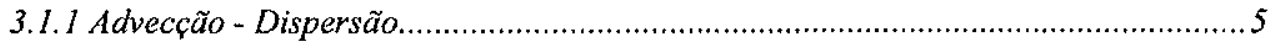

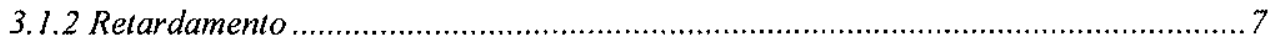

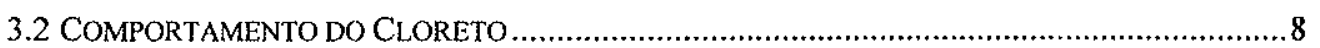

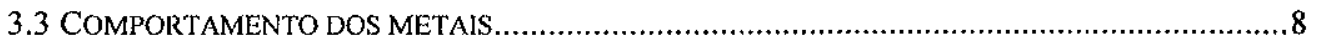

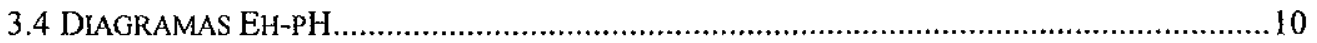

3.5 PADRÕES DE REFERÊNCIA PARA SOLO E ÁGUA SUBTERRÂNEA ....................................... 10

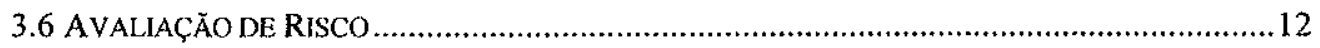

3.6.1 Formulação do Problema ........................................................................... 13

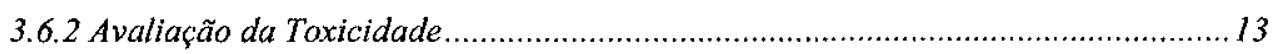

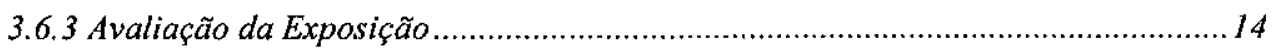

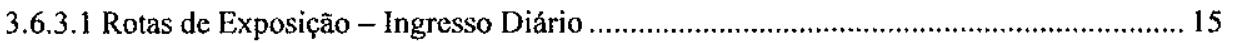

3.6.3.2 Estimativa de Ingresso Diário Crônico e para a Vida Toda ........................................... 18

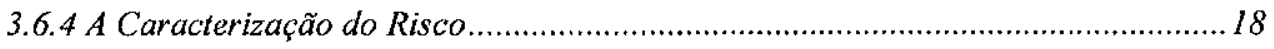

3.6.4.1 Estimativa do Risco para Efeitos Cancerígenos..................................................... 18

3.6.4.2 Estimativa do Risco para Efeitos Não Cancerígenos ................................................... 19

3.6.5 Etapas no Processo de Avaliação Segundo a Metodologia ASTM-RBCA ............. 19

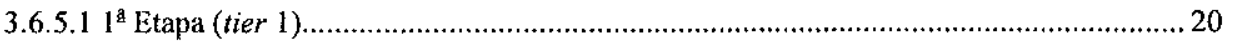

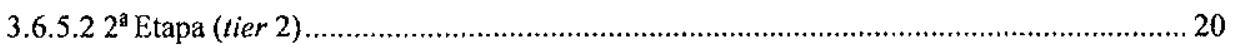

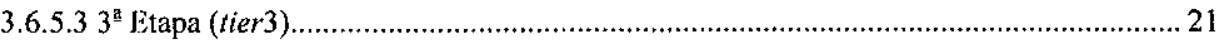

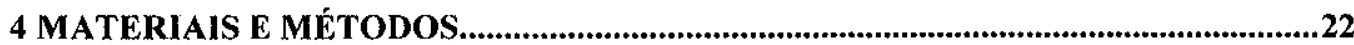

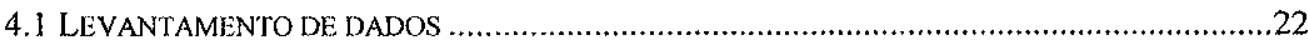

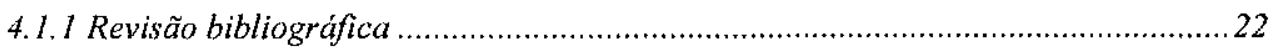




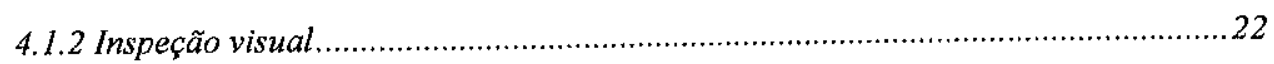

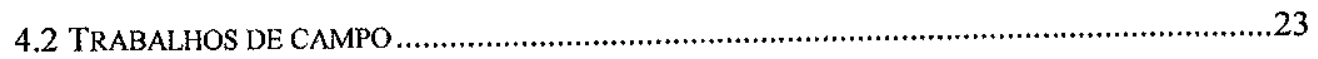

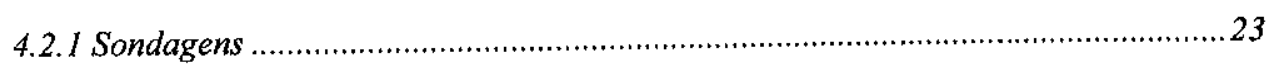

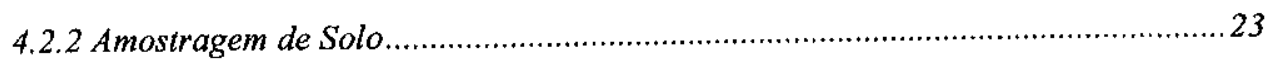

4.2.3 Instalação de Poços de Monitoramento .............................................................23

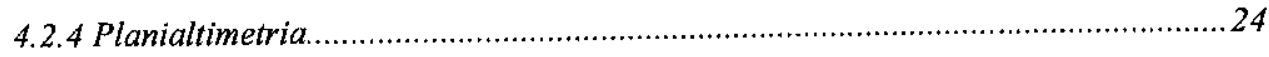

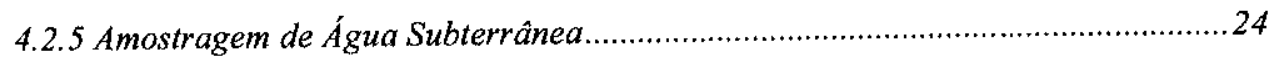

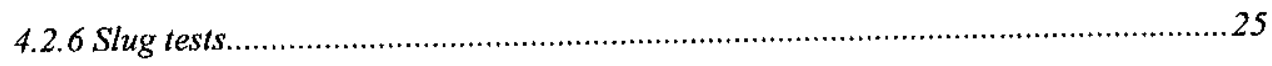

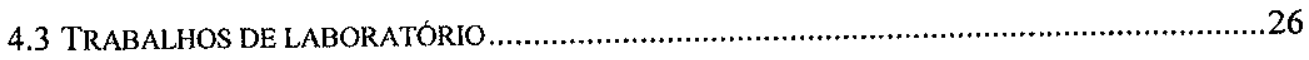

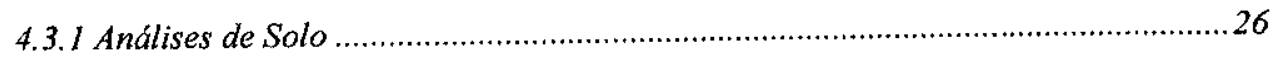

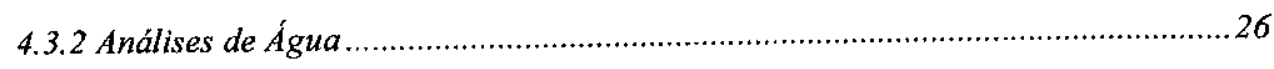

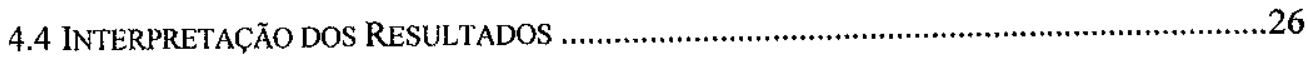

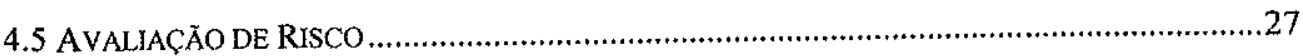

4.5.1 Desenvolvimento do cenário de risco..........................................................28

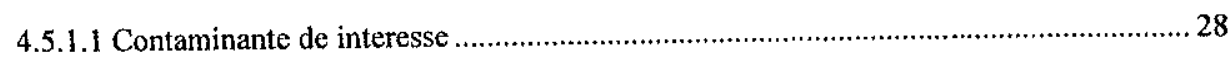

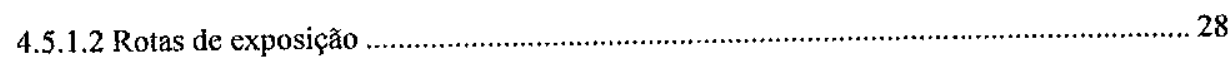

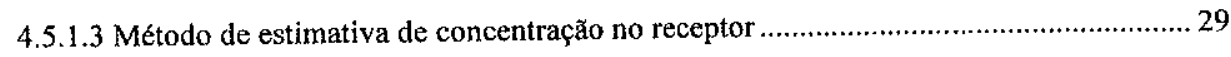

4.5.2 Destino e Transporte do Contaminante............................................................29

4.5.2.1 AT123D - Sistema de Coordenadas e Configuração da Fonte ...................................... 30

4.5.2.2 AT123D - Características Básicas do Modelo e sua Aplicabilidade ............................ 31

4.5.2.3 AT123D - Estimativa de concentração média em poço receptor ................................. 32

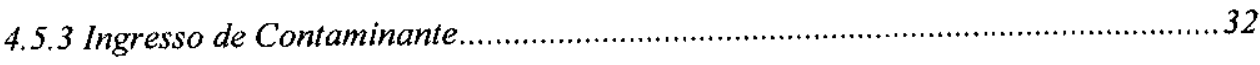

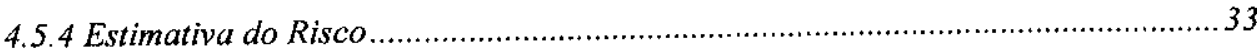

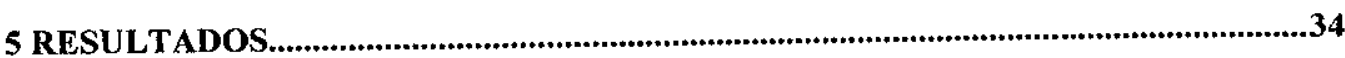

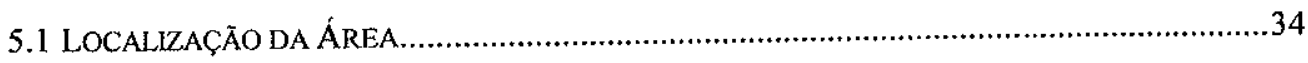

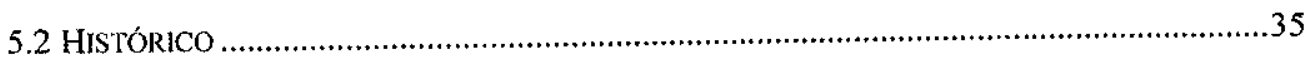

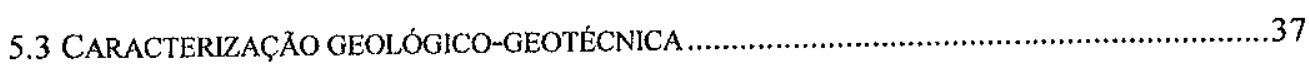

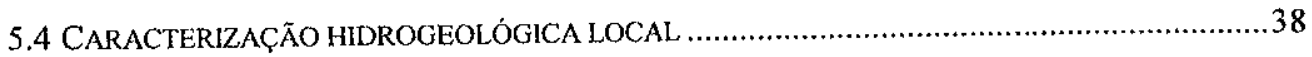

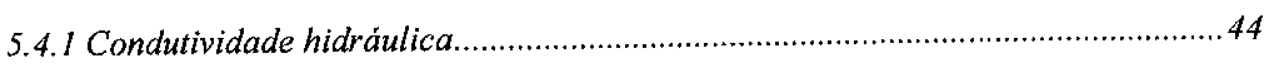

5.4 .2 Velocidade de fluxo da água subterrânea..........................................................45

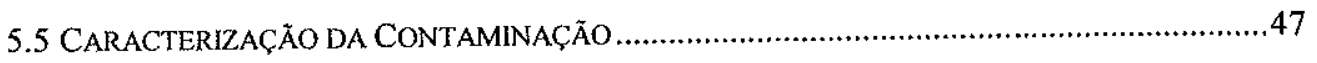

5.5.1 Caracterização da Contaminação do Solo ...........................................................47

5.5.2 Caracterização da Contaminação da Água Subterrânea......................................52

5.5.2.1 pH, Eh e Condutividade Elétrica ........................................................................... 53

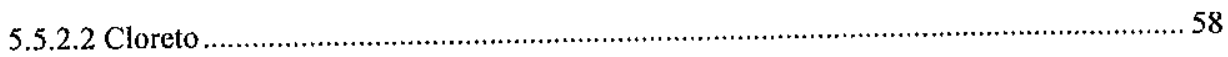

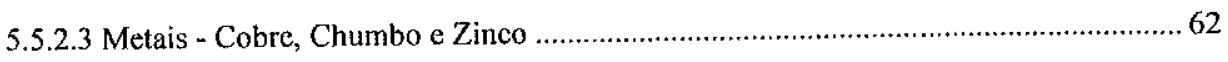

5.5 .3 Aguas Superficiais ............................................................................... 73

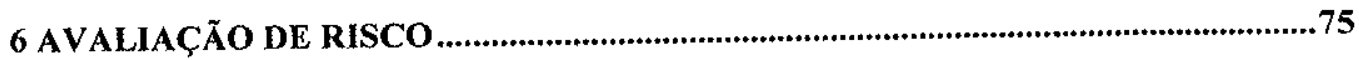




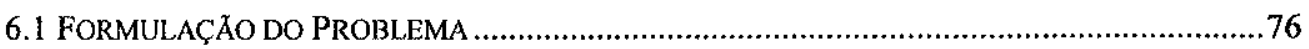

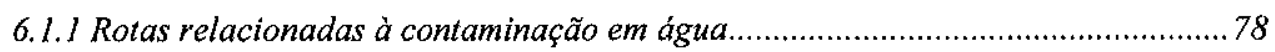

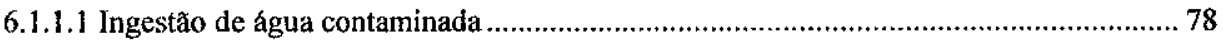

6.1.1.2 Contato dermal com água contaminada durante o banho …………............................ 78

6.1.2 Rotas relacionadas à contaminação em solo .......................................................79

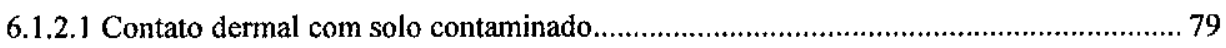

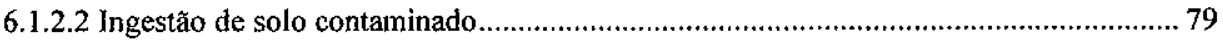

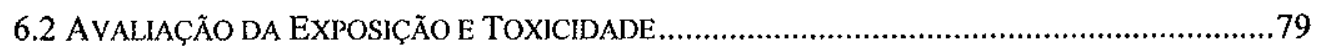

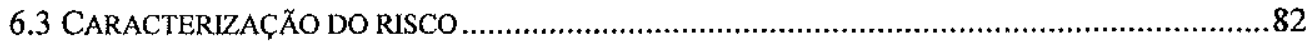

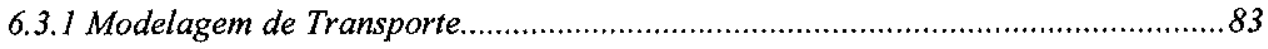

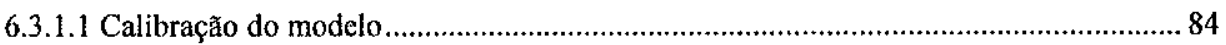

6.3.1.2 Simulaçðes de transporte ........................................................................................ 90

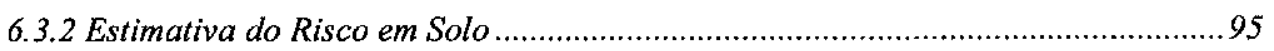

6.3.3 Estimativa do Risco em Água ......................................................................96

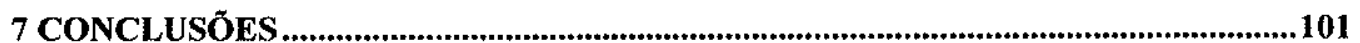

8 RECOMENDAÇÕES .............................................................................................................103

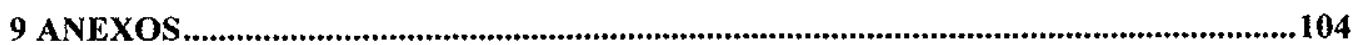

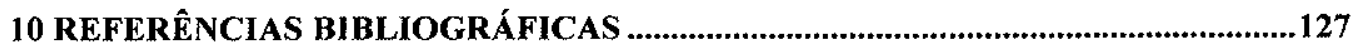




\section{AGRADECIMENTOS}

A "Empresa" que gentilmente autorizou a utilização dos seus dados.

À Coordenação de Aperfeiçoamento de Pessoal de Nível Superior - CAPES pela bolsa de estudos concedida.

Ao Curso de Pós-Graduação do Instituto de Geociências da Universidade de São Paulo pela possibilidade de realização deste trabalho.

A Hidroplan pela infra-estrutura colocada à disposição.

Aos colegas Dr. Everton de Oliveira e M.Sc. Celso Kolesnikovas pelo incentivo e orientação.

Ao M.Sc. Fernando "Agripino" Saraiva pelo incentivo.

Ao colega M.Sc. Flávio Augusto Ferlini Salles pelas sugestões e colaboração.

A todas as pessoas que direta ou indiretamente contribuíram de alguma maneira para que este trabalho pudesse ser realizado.

Ao Prof. Dr. Alberto Pacheco pela confiança depositada em meu trabalho. 


\section{LISTA DE TABELAS}

TABela 01 - PARÂmetros BÁsicos DE Referência (DEFault) Determinados Pelo API-DSS Para Simulações de Riscos, Modificado de API-DSS.

TABELA 02 - MEdidAS de NíveIS D'Água obTidos DURANTE OS EVENTOS DE MONITORAMENTO, ENTRE JUNHO DE 1998 E FEVEREIRO DE 2001.

TABELA 03 - POTENCIOMETRIA OBTIDA DURANTE OS EVENTOS DE MONITORAMENTO, ENTRE JUNHO DE 1998 E FEVEREIRO DE 2001.

TABELA 04 - VALORES de CONDUTIVIDADE HidRÁUliCA OBTIDOS A PARTIR DOS SLUG TESTS.

TABELA 05 - SUMÁRIO DOS PARÂMETROS HIDROGEOLÓGICOS.

TABELA 06 - SUMÁRIO DOS PARÂMETROS HIDROGEOLÓGICOS UTILIZADOS NAS SIMULAÇÕES DE TRANSPORTE.

TABela 07 - Resultados dasAnálises de Solo para Cloreto, em JUNHO DE 1998.

Tabela 08 - Resultados das ANÁlises Químicas - Amostras de Solo REMOVIDO EM AGOSTO DE 1998.

TABELA 09 - COMPARAÇÃo dOS VALORES DE CONCENTRAÇÃo EM SOLO COM OS VALORES ORIENTAdores do Sistema RAI PARA SOlo No ESTAdo de SÃo PAULO.

Tabela 10 - Padrões de Potabilidade estabelecidos pelos órgãos AMBIENTAIS.

TABela 11 - Resultados de PH EM Água SubTERrÂNeA

TABELA 12 - RESUltados de EH EM ÁGUA SUBTERRÂNEA

Tabela 13 - Resultados de Condutividade Elétrica em Água SUBTERRÂNEA

TABELA 14 - Resultados DE Cloreto EM ÁGUA SUbTERrÂnEA

Tabela 15 - Resultados de Cobre em Água SubterrâneA.

Tabela 16 - Resultados de Chumbo em ÁGua SubTerrânea.

TABELA 17 - REsultados de ZINCo EM ÁGUA SUbTERRÂNEA 
Tabela 18 - Padrões de Qualidade Ambiental - Água

TABELA 19 - ANÁlises de ÁguAs SuPERFICIAIS, FEVEREIRo de 1998.

TABEla 20 - PARÂMETros UTILIZAdos PARA SIMUlaÇões dE RISCOS POR ANÁlise DETERMINíSTICA, ModIFICADO DE API-DSS (1994) E CETESB (2000).

TABELA 21 - PARÂMETROS DE REFERÊNCIA UTILIZADOS PARA CALIBRAÇÃo DO MODELO.

TABELA 22 - PARÂMETROS UTILIZADOS PARA CALIBRAÇÃo DO MODELO.

TABela 23 - ParÂmetros utllizados para Modelagem DE TRANSPORTE.

TABELA 24 - Resultados das SimulaÇões de Risco efETUADAS.

TABela 25 - Resultados das Simulações de Risco efetuadas COM TRANSPORTE A PARTIR DA FONTE A.

TABela 26 - Resultados das Simulações de Risco efetuadas COM TRANSPORTE A PARTIR DA FONTE B.

TABELA 27 - VALORES DE SSTL ESTIMADOS 


\section{LISTA DE FIGURAS}

FIGURA 01 - GRÁFICO ESQUEMÁTICO DE TRANSPORTE ADVECTIVODISPERSIVO DE UM SOLUTO EM (A) UMA OU (B) DUAS DIMENSÕES. MODIFICADO DE DOMENICO E SCHWARTZ, 1998.

Figura 02 - Mapa de Localização da Área (SEm Escala). 34

Figura 03 - MaPa de LocalizaÇão dos Pontos InVEstigados. 36

Figura 04 - MAPA POTENCIOMÉTRICO - FEVEREIRO DE 1999.

FigURA 05 - MAPA POTENCIOMÉTRICO - FEVEREIRO DE 2001.

Figura 06 - Mapa de Isovalores de PH em Água SubterRÂNea FEVEREIRO DE 2001.

Figura 07 - Mapa de Isoconcentrações de Cloreto em Água SUBTERRÂNEA - MAIO DE 1999.

Figura 08 - Diagramas PH-EH PARA O SISTEMA Cl-O-H (MODIFICADO DE BROOKINS, 1988). OS DADOS PLOTADOS REFEREM-SE AOS POÇOS ATIVOS EM CADA EVENTO DE MONITORAMENTO REPRESENTADO.

Figura 09 - Diagramas PH-EH Para o SISTEMa Cu-O-H (BRoOKINS, 1988). OS DADOS PLOTADOS REFEREM-SE AOS POÇOS ATIVOS EM CADA EVENTO DE MONITORAMENTO REPRESENTADO.

64

Figura 10 - Mapa de Isoconcentrações de Chumbo em Água SUBTERRÂNEA - FEVEREIRO DE 2001.

Figura 11 - Diagramas PH-EH para o Sistema PB-S-C-O-H (BROOKINS, 1988). OS DADOS PLOTADOS REFEREM-SE AOS POÇOS ATIVOS EM CADA EVENTO DE MONITORAMENTO REPRESENTADO.

Figura 12 - MAPA DE IsOCONCENTRAÇÕES DE ZINCO EM ÁGUA SUBTERRÂNEA - FEVEREIRO DE 2001.

Figura 13 - Diagramas PH-EH PARA o SISTEMa ZN-O-H-S-C (BROOKINS, 1988). OS DADOS PLOTADOS REFEREM-SE AOS POÇOS ATIVOS EM CADA EVENTO DE MONITORAMENTO REPRESENTADO.

FIGURA 14 - VISUALIZAÇÃo TRIDIMENSIONAL DE FONTE SECUNDÁRYA ASSUMIDA EM TORNO DO PM-18.

Figura 15 - Gráfico ESQUemático de tranSPORTE ADVECTIVODISPERSIVO ENTRE PM-18 E PM-11.

FIGURA 16 - VISUALIZAÇÃo TRIDIMENSIONAL DE FONTE SECUNDÁRIA ASSUMIDA EM TORNO DO PM-07.

Figura 17 - CuRVAS DE DISTRIBUIÇÃO DAS CONCENTRAÇÕES DE CHUMBO NOS RECEPTORES SIMULADOS, A PARTIR DAS FONTES A E B. 


\section{LISTA DE SIGLAS}

APHA - American Public Health Association

API - AMERICAN PETRoleum INSTITUTE

API-DSS - AMERICAN PETROLEUM INSTITUTE EXPOSURE AND RISK DECISION SUPPORT SYSTEM

ASTM - AMERICAN SOCIETY FOR TESTING AND MATERIALS

AT123D - Analytical Transport One, Two and Three Dimensions

AWWA - AMERICAN WATER WORKS ASSOCIATION

CETESB - COMPANHIA dE TECNOLOGIA dE SANEAMENTO AMBIENTAL do Estado dE SÃo PaUlo

CONAMA - CONSElHo NACIONAL DE MEIo AMBIENTE

IRIS - INTEGRATED RISK INFORMATION SYSTEM

OMS - ORGANIZAÇÃo MUNDIAL DA SAÚDE

RBCA - RISK BASED CORRECTIVE ACTION

RBSL - RISK BASED SCREENING LEVEL

SABESP - COMPANHIA dE SANEAMENTO BÁSICO do Estado de SÃo Paulo

SSTL - SITE SPECIFIC TARgET LEVEL

USEPA - United States Environmental Protection Agency 


\section{RESUMO}

Este trabalho apresenta os resultados obtidos na avaliação da contaminação e do risco associado, em área às margens da rodovia Raposo Tavares e suas proximidades, no municipio de Cotia - SP.

O início dos estudos deveu-se à ocorrência de um vazamento de ácido cloridrico $(\mathrm{HCl})$ a partir de um tanque de armazenamento, utilizado nos processos de produção de uma Empresa, o que gerou uma pluma de cloretos e hidrogênio livre à jusante, atingindo o aqüffero livre. $O$ ambiente ácido gerado mobilizou metais em subsolo, provenientes de antigo tanque de efluentes da Empresa. Análises de metais foram realizadas $e$ as altas concentrações obtidas impuseram maior detalhamento em relação a estes contaminantes.

A partir de fonte situada na área da Empresa, a avaliação do local indicou concentrações acima dos padrões nacional e estadual em água subterrânea para cloreto, chumbo e zinco e para chumbo em solo. Determinou-se uma segunda fonte a jusante da primeira, a partir de uma empresa desativada vizinha, que apresentou contaminação de água subterrânea em concentrações maiores do que as referentes à primeira fonte, para chumbo e zinco.

As simulações de transporte efetuadas consideraram como pontos receptores o rio Cotia e poços de captação em possivel uso futuro da área. A partir das concentrações obtidas e simuladas, estimaram-se os riscos para os receptores determinados, considerando-se rotas de exposição para ingestão e contato dermal com solo e água subterrânea contaminados. Adotou-se o chumbo como contaminante de interesse, em função de suas caracteristicas deletérias à saúde.

O trabalho conclui pela existência de risco com efeitos não cancerígenos para os possiveis receptores, sem necessidade de medidas de intervenção imediatas. Valores alvo de concentração estimados para o local, para os quais considera-se não haver risco para os receptores, são mais altos do que os padrões estabelecidos.

Entretanto, recomenda-se a continuidade do monitoramento da área para avaliações futuras quanto a ações corretivas, visto que o cenário para estimativas de risco é de uso futuro da área. 


\section{ABSTRACT}

This work presents the assessment of the contamination and the associated risk results, in a site nearby the margins of the Raposo Tavares highway and its neighborhoods, in the city of Cotia - SP.

The beginning of the studies occurred due to a spill of chloridric acid ( $\mathrm{HCl}$ ) from a storage tank, used in the company production processes, that generated plumes of chlorides and free hydrogen downgradient, reaching the watertable. Metals coming from an old effluent tank were mobilized in subsurface, due the acid environment that was generated. Metal analyses had been done and high concentrations were founded, leading to detailing this issue.

From a source defined in the area of the Company, the site assessment indicated concentrations above the federal and local state standards for chloride, lead and zinc in groundwater and for lead in soil. A second source was determined downgradient from the first one, in a closed neighbour company, that presented groundwater contamination for lead and zinc in higher concentrations than the first source.

The receptors in the transport simulations were determined as being the Cotia river and eventual explotation wells, considering a future use for this area. There were estimated risks considering the intake routes for ingestion and dermal contact with contaminated soil and groundwater. The lead was defined as being the chemical of concern, due its deleterious effects to health.

The work concludes for the existence of non-carcinogenic adverse effects, without necessity of immediate intervention measures. Considering the absence of risk, the concentrations defined as being the site specific target levels are higher than the established standards.

However, it is recommended the monitoring of the site for future corrective action decisions, once the risk scenario is a eventual future use for the area. 


\section{INTRODUÇÃO}

A degradação das condições naturais de qualidade do solo e das águas, superficiais e subterrâneas, tem seu crescimento associado às atividades antropogênicas, através de incessante desenvolvimento industrial voltado às necessidades de sociedades cada vez mais exigentes.

Se por um lado o atendimento à sociedade traz melhor qualidade de vida ao cidadão, devido ao desenvolvimento tecnológico, traz também o ônus ambiental. Esta mesma sociedade cobra atualmente esta preservação ambiental. Desta forma, hoje em dia deve-se considerar qualquer desenvolvimento industrial em conjunto com preservação ambiental, não se admitindo qualquer hipótese diferente desta.

Neste contexto, a Região Metropolitana de São Paulo assume papel de destaque, através do desenvolvimento industrial das últimas décadas em meio a um crescimento urbano tão ou mais intenso e sem planejamento da ocupação. Este tipo de uso e ocupação do solo, industrial e residencial, revelam-se incompatíveis e, em conseqüência, oferecem riscos à população em função dos niveis de contaminação do solo e água subterrânea que freqüentemente ocorrem.

Vazamentos acidentais de tanques de armazenamento de compostos químicos e de efluentes industriais têm gerado inúmeros casos de contaminações de solo e principalmente água, com destaque para a água subterrânea, de percepção e avaliação da contaminação mais complexas.

A captação de água subterrânea através de poços rasos, tipo cacimba, é comum em áreas periféricas de zonas residenciais e industriais, geralmente em captações não cadastradas e de difícil levantamento de dados. Este tipo de uso da água subterrânea sofre um incremento com a dificuldade de abastecimento dos sistemas públicos, somando-se o advento do custo cada vez maior da água distribuída e admissão de um aumento futuro no uso de água subterrânea.

Diante deste quadro, as agências ambientais vêm aumentando cada vez mais a fiscalização aos potenciais poluidores. Avaliações da ocorrência elou grau de contaminação de solo e água subterrânea têm sido cada vez mais freqüentes, no sentido de detectar estas contaminações para a tomada de medidas de controle ou 
remediação.

Além disso, as indústrias desativadas e sem controle ambiental, podem apresentar um passivo ambiental de proporções bastante significativas, como observado neste trabalho.

Avaliações de contaminação, a partir de métodos diretos de investigação, envolvem a caracterização hidrogeológica da área, identificação e mecanismos de transporte do(s) contaminante(s), contemplando levantamentos de parâmetros físico-quimicos do solo e da água subterrânea do local.

Ao mesmo tempo que o controle e fiscalização ocorrem, as agências e órgãos ambientais têm concentrado esforços em criar e regulamentar normas em niveis estadual e nacional. Outra alternativa é a adaptação de normas internacionais para a avaliação de contaminações e dos riscos associados para a população, através do desenvolvimento de metodologias em acordo com a problemática local.

O Ministério da Saúde, através da Portaria 1469 (2000), estabelece procedimentos e responsabilidades relativos ao padrão de potabilidade da água para consumo humano.

A Companhia de Tecnologia de Saneamento Ambiental do Estado de São Paulo - CETESB (2001), após comparação e avaliação de várias normas e legislações internacionais, adotou a metodologia holandesa como base para o estabelecimento de valores orientadores, para solos e águas subterrâneas, próprios para o Estado de São Paulo.

Este trabalho propõe a formalização do denominado Sistema RAl, com a regulamentação de valores referência de qualidade $(R)$, valores de alerta $(A)$ e valores de intervenção (I). A adoção destes valores serve para orientar na proteção da qualidade dos solos e águas subterrâneas, bem como no controle de áreas contaminadas ou suspeitas de contaminação.

Diante de cenários de contaminação, os altos custos e o longo tempo necessários para remediação de locais contaminados, associados à ineficiência em se atingir padrões de potabilidade, têm inviabilizado projetos de remediação. A avaliação de risco aparece como importante processo para condução das ações corretivas a serem implantadas.

A partir da avaliação de risco, novos padrões podem ser estabelecidos, em 
função de contaminação e exposição a receptores em um cenário específico para o local e, ainda assim, garantir-se proteção à população quanto aos efeitos deletérios desta exposição à contaminação caracterizada.

A American Society for Testing and Materials - ASTM homologou uma metodologia denominada Risk Based Corrective Action - RBCA, que consiste numa metodologia de ações corretivas baseadas no risco, que propõe uma seqüência de medidas desde a suspeita de contaminação até a meta final de remediação proposta para o local.

Este trabalho apresenta a avaliação da contaminação por alguns compostos inorgânicos em solo e água subterrânea e a avaliação do risco associado, utilizandose a metodologia ASTM-RBCA. 


\section{OBJETIVOS}

Avaliação da contaminação do solo e água subterrânea em área de Empresa situada à margem da rodovia Raposo Tavares e suas adjacências,

$>$ Avaliação do risco associado à exposição para possiveis receptores. 


\section{REVISÃO BIBLIOGRÁFICA}

Neste capitulo abordou-se de forma concisa alguns conceitos de interesse ao trabalho, envolvendo mecanismos de transporte dos contaminantes avaliados em água subterrânea e seus aspectos hidrogeoquimícos, normas ambientais e conceitos básicos de avaliação de risco.

\subsection{Mecanismos de transporte}

A seguir estão apresentados os conceitos básicos de advecção, dispersão e retardamento no transporte de contaminantes.

\subsubsection{Advecção - Dispersão}

A advecção é o mecanismo pelo qual o transporte de um soluto é dado pelo fluxo de água subterrânea. A velocidade linear média da água subterrânea $\left(v_{x}\right)$ pode ser obtida a partir da equação de Darcy, como segue :

$$
\mathrm{v}_{\mathrm{x}}=\frac{\mathrm{K}_{\mathrm{i}}}{\eta_{\mathrm{e}}} \quad \text { (equação 01) }
$$

Onde:

$$
\begin{aligned}
& v_{x} \text { - velocidade linear média (longitudinal) }[L / T] \\
& K \text { - condutividade hidráulica }[L / T] \\
& i \text { - gradiente hidráulico }[-] \\
& \eta_{e} \text { - porosidade efetiva }[-]
\end{aligned}
$$

A dispersão é o espalhamento de um soluto no fluxo subterrâneo através do meio poroso, misturando-se com água subterrânea não contaminada. $A$ dispersão ocorre nas três direções de eixos de coordenadas. Ao longo das linhas de fluxo é denominada dispersão longitudinal, enquanto transversais às linhas de fluxo, 
denominadas dispersão lateral e vertical.

Segundo Fetter (1994), a dispersão longitudinal ocorre por três razões básicas: 1 - o fluido se move mais rápido ao longo do centro dos poros do que nas suas bordas; 2 - alguns caminhos percorridos são mais longos do que outros; 3 - o fluido se move mais rápido em poros maiores do que em menores. A dispersão lateral é causada pelo fato de que fluido (água com contaminante) pode dividir-se e ramificar-se lateralmente, em condições de fluxo laminar, que prevalece no fluxo de água subterrânea.

A principal equação diferencial de advecção-dispersão, que descreve o transporte unidimensional de solutos não reativos em meio saturado, homogêneo, isotrópico, em equilibrio e fluxo uniforme está apresentada abaixo (Freeze \& Cherry, 1979):

$$
\mathrm{D}_{\mathrm{x}} \frac{\partial^{2} \mathrm{C}}{\partial \mathrm{x}^{2}}-\mathrm{v}_{\mathrm{x}} \frac{\partial \mathrm{C}}{\partial \mathrm{x}}=\frac{\partial \mathrm{C}}{\partial \mathrm{t}} \quad \text { (equação 02) }
$$

Onde:

$$
\begin{aligned}
& D_{x}=\text { coeficiente de dispersão hidrodinâmica longitudinal }\left[\mathrm{L}^{2} / T\right] \\
& x=\text { distância longitudinal ao longo da linha de fluxo }[\mathrm{L}] \\
& C=\text { concentração do soluto }\left[\mathrm{ML}^{3}\right]
\end{aligned}
$$

Efeitos de reações químicas, transformações biológicas e decaimento não estão considerados nesta equação de transporte.

O coeficiente de dispersão hidrodinâmica pode ser expresso como segue:

$$
D_{x}=\alpha \cdot v_{x}+D_{f} \quad \text { (equação 03) }
$$

Onde:

$$
\begin{aligned}
& \alpha=\text { dispersividade }[\mathrm{L}] \\
& D_{f}=\text { coeficiente de difusão molecular do soluto no meio }\left[\mathrm{L}^{2} / T\right]
\end{aligned}
$$




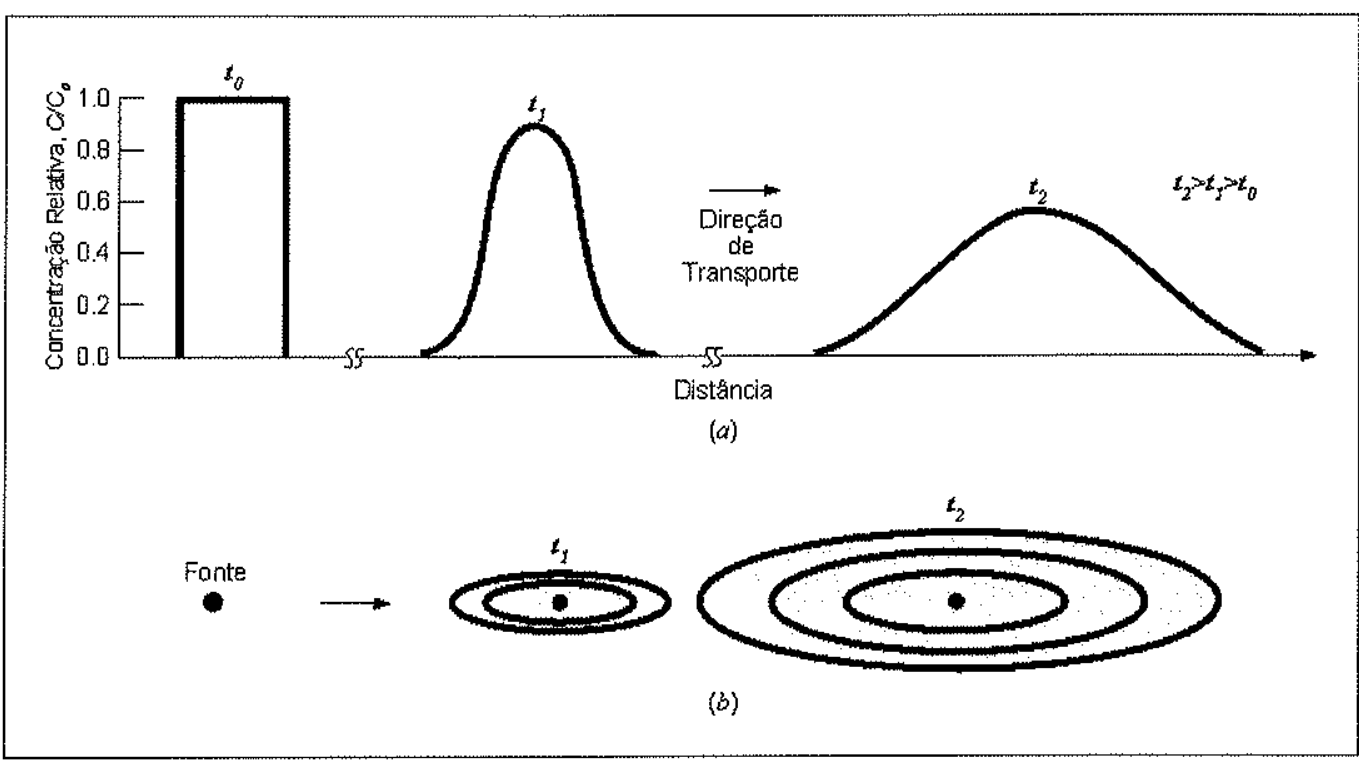

Figura 01 - Gráfico esquemático de transporte advectivo-dispersivo de um soluto em (a) uma ou (b) duas dimensões, em um sistema de fluxo constante. Modificado de Domenico e Schwartz, 1998.

\subsubsection{Retardamento}

O retardamento é a diferença entre o movimento de um soluto em relação ao fluxo subterrâneo de água, em função de caracteristicas reativas do soluto, como adsorção à matéria orgânica e minerais argilosos, troca iônica e outras. O fator de retardamento pode ser expresso através da seguinte equação linear:

$$
\mathrm{R}=1+\frac{\mathrm{K}_{\mathrm{d}} \rho}{\eta_{\mathrm{e}}} \quad \text { (equação 04) }
$$

Onde:

$$
\begin{aligned}
& R=\text { fator de retardamento }[-] \\
& k_{d}=\text { coeficiente de distribuição solo-água }\left[L^{3} M\right] \\
& \rho=\text { densidade do solo }\left[M / L^{3}\right] \\
& \eta_{\theta}=\text { porosidade efetiva }[-]
\end{aligned}
$$

$O k_{d}$ é a medida do parcionamento de um composto metálico ou inorgânico, entre o solo e a água. Quanto maior o $k_{d}$, maior a tendência do contaminante ser adsorvido ao solo (CETESB, 2000) 


\subsection{Comportamento do Cloreto}

Cloreto ocorre naturalmente em águas em concentrações relativamente baixas, geralmente menores que $100 \mathrm{mg} / \mathrm{L}$, a menos que a água seja salobra ou salina. Trata-se de um ion não reativo. Ele não participa de reações redox, não é adsonido em superfícies minerais ou de matéria orgânica e não forma precipitados insolúveis. Cloreto pode ser utilizado em estudos hidrogeológicos como traçador por causa de suas caracteristicas conservativas (Fetter, 1993). Solutos consenvativos não reagem com solos ou águas subterrâneas, nem sofrem decaimento (Palmer, 1996).

Matthess (1982) apresenta concentrações médias de cloreto em rochas igneas de $305 \mathrm{mg} / \mathrm{kg}$, em arenitos de $15 \mathrm{mg} / \mathrm{kg}$ e em rochas argilosas de $170 \mathrm{mg} / \mathrm{kg}$, em horizonte próximos da superfície. Água subterrânea em meio a rochas igneas e sedimentares geralmente mostram concentrações menores que $30 \mathrm{mg} / \mathrm{L}$; quando maiores, indicam mistura com águas mineralizadas ou interferência antrópica.

\subsection{Comportamento dos metais}

A maioria dos metais em água subterrânea ocorrem em baixas concentrações, de alguns $m g / L$ ou menores (< $1 \mathrm{mg} / \mathrm{L}$ ). As concentrações são baixas por causa da restrição imposta pela solubilidade de minerais ou substâncias amorfas, adsorção em argilo-minerais ou em hidróxidos de ferro e manganês ou matéria orgânica (Freeze \& Cherry, 1979).

Segundo CETESB (2000), em água as concentrações de chumbo geralmente estão abaixo de $5 \mu \mathrm{g} / \mathrm{L}$, de cobre geralmente abaixo de $20 \mu \mathrm{g} / \mathrm{L}$ e de zinco normalmente abaixo de $320 \mu \mathrm{g} / \mathrm{L}$. Em solo, podem-se admitir como concentrações médias as determinadas pela CETESB (2000) como referência de qualidade para solos limpos no Estado de São Paulo, de $17 \mathrm{mg} / \mathrm{kg}$ para chumbo, de $35 \mathrm{mg} / \mathrm{kg}$ para cobre e de $60 \mathrm{mg} / \mathrm{kg}$ para zinco.

Uma característica da maioria dos metais em água é sua tendência em formar espécies hidrolisadas e complexadas pela combinação com ânions inorgânicos 
como $\mathrm{HCO}_{3}{ }^{-}, \mathrm{CO}_{3}{ }^{2-}, \mathrm{SO}_{4}{ }^{2-}, \mathrm{Cl}^{-}, \mathrm{F}^{-}$e $\mathrm{NO}_{3}{ }^{-}$. A ocorrência e a mobilidade de um metal em água subterrânea requer considerações a respeito destas espécies dissolvidas. Análises químicas de um metal em água subterrânea formece informação direta somente do conteúdo total do metal em água. O percentual da concentração total das espécies hidrolizadas existentes aumenta com o aumento do $\mathrm{pH}$ da água (Freeze \& Cherry, 1979).

Condições que promovem mobilidade aos metais incluem um solo arenoso e ácido, com baixos conteúdos de matéria orgânica e argila. Metal em meio a uma solução ácida mantém-se solúvel e móvel (Fetter, 1999). Palmer (1996) escreve que o pH da água é uma medida de suas características reativas. Baixos valores de $\mathrm{pH}$, particularmente abaixo de 4, indicam uma água corrosiva, que tenderá a dissolver metais e outras substâncias em contato.

Pode-se resumir em três principais zonas de transporte de metais (Sracek, 1998) :

Zona oxidada: onde há presença de $\mathrm{O}_{2}, \mathrm{o} \mathrm{Fe}^{3+}$ precipita como $\mathrm{Fe}(\mathrm{OH})_{3} \mathrm{e}$ carrea metais, entretanto, o $\mathrm{Fe}(\mathrm{OH})_{3}$ é uma fase mineral instável e pode re-dissolver e liberar metais quando $\mathrm{pH}$ e Eh mudam;

Zona intermediária: com ausência de $\mathrm{O}_{2}$ e $\mathrm{Fe}^{3+}$, os metais são relativamente móveis e há presença de $\mathrm{SO}_{4}{ }^{2-}$;

Zona reduzida: apresenta ausência de $\mathrm{O}_{2}, \mathrm{Fe}^{3+}$ e $\mathrm{SO}_{4}{ }^{2-}$, com a presença de $\mathrm{HS}^{-}$e $\mathrm{H}_{2} \mathrm{~S}$. Os metais são removidos pela precipitação e co-precipitação com sulfetos secundários como pirita, galena e outros.

Em relação ao chumbo, adotado como contaminante de interesse no trabalho, Fetter (1999) afirma que os dois fatores mais importantes para determinar a quantia de chumbo adsorvida ao solo são o pH e a capacidade de troca catiônica (CTC) do solo, que depende da quantia e tipo de argila e da quantia de matéria orgânica no solo. Há uma relação que mostra que para pH maiores que 4,61 a quantia de chumbo adsorvida pelo solo aumenta e para $\mathrm{pH}$ menores que 4,61, ela diminui.

Quando as concentrações numa fonte de chumbo são altas, a quantia de chumbo que entra no subsolo pode exceder a capacidade de imobilização do sistema, permitindo que o chumbo seja relativamente móvel. Pode-se resumir a 
capacidade de adsorção relativa dos constituintes individuais do solo para o chumbo como decrescentes na ordem de óxidos de $\mathrm{Mn}$, óxidos de $\mathrm{Fe}$, matéria orgânica e minerais de argila (Deutsch, 1997).

\subsection{Diagramas Eh-pH}

A relação entre Eh e $\mathrm{pH}$ é particularmente útil quando aplicada na forma de um diagrama $\mathrm{Eh}$-pH, que mostra os campos de estabilidade para várias espécies químicas, com o pH no eixo das abscissas e o Eh no eixo das ordenadas. Se uma solução tem vários íons presentes que podem reagir para formar produtos diferentes ou ocorrem em diferentes estados de valência, o produto estável ou estado de valência de uma dada concentração de reagentes será função do Eh e pH da solução (Fetter, 1993).

As variações de pressão e temperatura pouco afetam os limites dos diagramas, explicando sua grande utilidade (Fenzl, 1988).

\subsection{Padröes de Referência para Solo e Água Subterrânea}

Atualmente, todos os paises que consideram seriamente a proteção do solo e água subterrânea, estão tentando encontrar um meio termo entre o uso de critério numéricos (valores orientadores) e a avaliação de risco caso a caso. Assim, concluise que para o Estado de São Paulo, a melhor alternativa é a adoção de uma estratégia combinada, utilizando-se uma lista de valores de referência de qualidade para o monitoramento da qualidade do solo e água subterrânea e valores de intervenção, para diagnóstico e apoio às ações de controle das áreas contaminadas, com a avaliação de risco realizada onde julgado necessário (CETESB, 2000).

Assim, baseado em metodologias internacionais e tomando-se como base a metodologia holandesa de desenvolvimento de valores orientadores, formalizou-se o "Sistema RAl". Este trabalho é o único no país que contém padrões de referência para solos, que apresenta três valores de referência para concentrações de compostos ou elementos químicos de interesse, considerando-se dois grupos de 
substâncias: as naturalmente ausentes (antropogênicas) e as naturalmente presentes.

Os Valores de Referência de Qualidade $(R)$ foram estabelecidos como limites abaixo dos quais consideram-se os solos como limpos e não portadores de problemas de qualidade ambiental. Os Valores de Alerta (A), indicam a alteração das propriedades funcionais $e$, quando excedidos, indicam a necessidade de execução de investigações detalhadas e monitoramento. Por último, o sistema estabelece os Valores de Intervenção (l), que, quando ultrapassados, indicam a necessidade de tomada de ações interventoras, pois acima deles considera-se que a contaminação alcançou níveis que representam risco à saúde humana. O sistema RAI estabelece Valores de Intervenção (I) para áreas de proteção máxima e/ou agrícolas, residenciais e industriais.

Para a água subterrânea, como $R$, para substâncias inorgânicas, prevalece a qualidade natural do aqüifero (que pode ser variável conforme características de cada aqüifero), uma vez que se tratam de substâncias naturalmente presentes em água. Para as substâncias naturalmente ausentes em água, prevalecem os limites de detecção dos métodos analíticos usuais. Assim, ficam propostos somente valores de intervenção (I). Os limites de interesse para este trabalho estão apresentados na tabela 09 para solo e na tabela 10 para água subterrânea.

A Portaria 1469, de dezembro de 2000, emitida pelo Ministério da Saúde em substituição à Portaria 36 de 1990, estabelece os procedimentos e responsabilidades relativos ao controle e vigilância da qualidade da água para consumo humano e seu padrão de potabilidade.

A portaria define como água potável a água para consumo humano cujos parâmetros microbiológicos, físicos, químicos e radioativos atendam ao padrâo de potabilidade e não ofereça riscos à saúde. Como solução alternativa de abastecimento de água para consumo humano, consideram-se todas as modalidades distintas do sistema de abastecimento, incluindo fontes, poços (comunitários) e outras.

Ao responsável por solução alternativa cabe providenciar autorização junto ao órgão público de saúde, com análises de qualidade da água, operar o sistema de acordo com normas técnicas, manter e controlar a qualidade da água, manter 
registros da qualidade da água e comunicar às autoridades e o consumidor (população) a deteç̧ão de qualquer anomalia identificada como risco à saúde.

A portaria estabelece os padrões das substâncias químicas que representam risco para o consumo. Os padrões de interesse para este trabalho estão apresentados na tabela 10.

\subsection{Avaliação de Risco}

A metodologia de avaliação de risco envolve duas fases, a avaliação de risco propriamente dita e o gerenciamento deste risco. A avaliação de risco refere-se a uma avaliação técnica da natureza e magnitude do risco, enquanto o gerenciamento do risco é o processo de avaliação e seleção das ações apropriadas para o controle do perigo e atenuação de suas conseqüências (Finotti, 1997 apud Chechile \& Carlisle, 1991). Estas duas fases estão intimamente relacionadas, com a avaliação de risco sendo o instrumento técnico a partir do qual decisões políticas serão tomadas pelos órgãos ambientais, para o gerenciamento do risco caracterizado.

A American Society for Testing and Materials - ASTM homologou uma metodologia denominada Risk Based Corrective Action - RBCA, a partir da necessidade, nos Estados Unidos da América (EUA), de um guia para nortear o programa de remediação de solos contaminados por resíduos perigosos. Trata-se de um auxiliar de tomada de decisão aplicado à contaminação de solos e águas subterrâneas, que tem por base a proteção da saúde humana e recursos ambientais. As práticas tradicionais de remediação foram incorporadas à avaliação de risco, com o objetivo de instrumentalizar a priorização de locais contaminados e escolha do grau de remediação, em função do risco que representam aos receptores envolvidos.

A metodologia ASTM - RBCA pode ser descrita por uma série de passos, que cobrem desde a coleta de dados até o monitoramento após a remediação do sítio. As etapas de análise são seqüenciais e têm sua complexidade aumentada, refinamento de cálculos, modelos e dados requeridos, sendo acessadas à medida que seja apontada a necessidade de estudos mais aprofundados do local. 
O conceito fundamental de avaliação de risco está baseado em três componentes essenciais: contaminantes perigosos, vetores (rotas) de exposição $\mathrm{e}$ receptores, que formam o trinómio de risco.

O desenvolvimento do estudo baseia-se na execução de quatro fases principais, que resultam numa avaliação dos riscos provocados pela exposição ao contaminante que seja cientificamente defensável, descritas abaixo:

\subsubsection{Formulação do Problema}

É a primeira fase da avaliação de risco e envolve a definição dos três principais componentes do risco à saúde humana: compostos químicos, vetores (rotas) de exposição e receptores. Consiste na coleta e análise dos dados, através do levantamento das informações disponíveis para a caracterização do local em termos de fonte, meio, compostos de interesse e características do receptor, relevantes para a avaliação do risco associado(s) aos composto(s) de interesse.

A definição é baseada em considerações especificas do local, incluindo os cenários de atividades e uso do local. O objetivo da formulação do problema é criar um modelo conceitual que servirá de base para delimitação da avaliação de risco quantitativa somente àqueles contaminantes, vetores e receptores que apresentem - maior potencial de contribuição para um risco mensurável, baseada em levantamentos adequados sobre o meio contaminado, contaminante(s) em questão, tipo(s) e localização do(s) receptor(es) e vetores de exposição.

\subsubsection{Avaliação da Toxicidade}

A Avaliação da Toxicidade é feita para os compostos químicos analisados. Ela envolve a identificação dos efeitos tóxicos potenciais associados à exposição a estes compostos e a estimativa da dosagem máxima para cada composto que não causa efeitos adversos mensuráveis para os receptores em questão (dose de segurança). A dose resposta é estimada para três formas de assimilação: ingestão, inalação e contato cutâneo e usada posteriormente para se obter matematicamente uma estimativa de risco. Nesta etapa devem-se considerar as incertezas 
relacionadas à toxicidade do(s) composto(s).

Da avaliação da dose resposta obtêm-se os coeficientes para a quantificação dos riscos. Para compostos cancerigenos denomina-se fator de potência - FP (slope factor), que representa o risco produzido pela exposição diária ao longo de toda a vida do indivíduo a $1 \mathrm{mg} / \mathrm{kg}$. dia do composto. Para os compostos não cancerígenos (sistêmicos) é a dose de referência - DRf, (reference dose) que é uma estimativa (com uma faixa de incerteza de até uma ordem de grandeza) de exposição diária média para uma população humana, que provavelmente está ausente de um risco apreciável de efeitos deletérios durante a vida.

Em relação aos efeitos não cancerígenos, a Organização Mundial da Saúde OMS homologou o parâmetro denominado IDT - Ingresso Diário Tolerável (Tolerable Daily Intake), que pode substituir o parâmetro DRf. O IDT significa a dose (ingresso) diária, dada em $\mathrm{mg}$ da substância por $\mathrm{kg}$ de peso do corpo do indivíduo por dia, até a qual não se espera nenhum efeito adverso à saúde do indivíduo (CETESB, 2000).

\subsubsection{Avaliação da Exposição}

Consiste em estimar a magnitude real ou potencial, rota(s), freqüência e duração da exposição, entre o receptor e o composto. Envolve a estimativa da assimilação (ingestão, inalação ou absorção cutânea) diária, pelo receptor, de compostos químicos associados ao local contaminado. A assimilação diária total para um composto químico especifico é a somatória das assimilações diárias para cada vetor identificado na formulação do problema como sendo de interesse. A assimilação diária total (ou taxa de exposição observada) através de ingestão, inalação e contato cutâneo é usado posteriormente na caracterização do risco para se obter, matematicamente, uma estimativa de risco.

A avaliação do ingresso de contaminante no organismo utiliza-se de equações que incluem variáveis como concentração; freqüência, duração e tempo médio de exposição, peso do corpo e taxas de contato. Esta estimativa é usada para a quantificação do risco para cada rota de exposição. 


\subsubsection{Rotas de Exposição - Ingresso Diário}

A seguir estão expostas as rotas de interesse para o trabalho. As rotas de inalação foram descartadas devido à pressão de vapor nula do chumbo.

\section{Ingestão de Água}

O ingresso diário de contaminante através da ingestão de água é medido pela taxa de ingestão e a concentração do contaminante na água consumida.

$$
I D=\beta_{i} . T I . C_{\text {água }} / P C \quad \text { (equação 05) }
$$

Onde :

$1 D$ = ingresso diário da substância através da ingestão de água [ $\mathrm{mg} / \mathrm{kg}$-dia]

$T I=$ taxa de ingestão de água contaminada [L/dia]

$C_{a ́ g u a ~}=$ concentração do contaminante na água $[\mathrm{mg} / \mathrm{L}]$

$P C=$ peso do corpo $[\mathrm{kg}]$

$\beta_{i}=$ biodisponibilidade química especifica para ingestão $[\mathrm{mg} / \mathrm{mg}]$

Deve-se atentar que a taxa de ingestão refere-se somente à água contaminada. Trata-se de uma estimativa conservadora, uma vez que não considera a diluição da água contaminada.

\section{Contato Dermal durante o banho}

Durante o banho as pessoas absorvem contaminantes dissolvidos através da pele para a corrente sangüinea. A dose em pessoas é medida como a dose absorvida em vez de dose administrada.

$$
I D_{a b s}=10^{-3} \cdot C_{\text {água }} \cdot A S \cdot C P \cdot \text {. TE } / P C \quad \text { (equação 06) }
$$

Onde :

$$
\begin{aligned}
& I D_{\text {abs }}=\text { dose diária absorvida pelo ingresso dermal }[\mathrm{mg} / \mathrm{kg} \text {-dia }] \\
& C_{\text {aggua }}=\text { concentração do contaminante na água }[\mathrm{mg} / \mathrm{L}] \\
& A S=\text { superficie exposta da pele }\left[\mathrm{cm}^{2}\right] \\
& C P=\text { coeficiente especifico de permeabilidade da pele }[\mathrm{cm} / \mathrm{h}] \\
& T E=\text { duração do banho }[\mathrm{h} / \text { dia }] \\
& P C=\text { peso do corpo }[\mathrm{kg}] \\
& 10^{-3}=\text { fator de conversão }\left[\mathrm{L} \mathrm{cm}^{3}\right]
\end{aligned}
$$




\section{Ingestão de Solo}

Adultos podem ingerir solo contaminado através do contato involuntário das mãos e roupas com a boca. Em crianças esta rota pode ser considerada primária (Paustenbach, 1989 apud API-DSS). O ingresso diário pode ser estimado como segue.

$$
I D=10^{-6} \cdot \beta_{s} \cdot C_{s} \cdot T I . F I / P C \quad \text { (equação 07) }
$$

Onde :

$$
\begin{aligned}
& I D=\text { ingresso diário da substância pela ingestão de solo }[\mathrm{mg} / \mathrm{kg} \text {-dia }] \\
& C_{s}=\text { concentração de contaminante em solo }[\mathrm{mg} / \mathrm{kg}] \\
& T I=\text { taxa de ingestão de solo contaminado }[\mathrm{mg} / \mathrm{dia}] \\
& \mathrm{FI}=\text { fração do solo ingerido que está contaminada }[\mathrm{H} \\
& P C=\text { peso do corpo }[\mathrm{kg}] \\
& 10^{-6}=\text { fator de conversão }[\mathrm{kg} / \mathrm{mg}] \\
& \beta_{s}=\text { biodisponibilidade química especifica para ingestão }[\mathrm{mg} / \mathrm{mg}]
\end{aligned}
$$

Cabe ressaltar que a quantia diária de solo ingerida por adultos e crianças é bastante incerta.

\section{Contato Dermal com Solo}

Solos contaminados podem ser absorvidos através da pele para a corrente sangüinea. A dose absorvida pode ser estimada como segue.

$$
I D_{a b s}=10^{-6} \cdot C_{s} \cdot A S \cdot F A \cdot A B S / P C \quad \text { (equaçăo 08) }
$$

Onde:

$$
\begin{aligned}
& I D_{a b s}=\text { dose diária absonida pelo ingresso dermal }[\mathrm{mg} / \mathrm{kg} \text {-dia] } \\
& C_{s}=\text { concentração de contaminante em solo }[\mathrm{mg} / \mathrm{kg}] \\
& A S=\text { superfície da pele exposta ao solo }\left[\mathrm{cm}^{2} / \mathrm{dia}\right] \\
& F A=\text { fator de aderência do solo à pele }\left[\mathrm{mg} / \mathrm{cm}^{2}\right] \\
& A B S=\text { fração de contaminante que é absorvida }[\mathrm{mg} / \mathrm{mg}] \\
& P C=\text { peso do corpo }[\mathrm{kg}] \\
& 10^{-6}=\text { fator de conversão }[\mathrm{kg} / \mathrm{mg}]
\end{aligned}
$$

O fator de absorção de solo através da pele raramente é conhecido para um composto específico. Ryan et al. (1986) apud API-DSS estimam este fator para 
compostos inorgânicos entre 0,1 e $1 \%$.

A seguir é apresentada uma tabela de ingresso de contaminante que mostra dois tipos de dados de entrada para o modelo, um primeiro que assume valores máximos de exposição e um segundo que assume valores médios mais comuns, ressaltando-se que há possibilidade de utilização de dados próprios.

Tabela 01 - Parâmetros Básicos de Referência (Default) Determinados Pelo API-DSS Para Simulações de Riscos, Modificado de API-DSS.

\begin{tabular}{|c|c|c|c|}
\hline Parâmetro & Unidade & $\begin{array}{l}\text { Valor Máximo de } \\
\text { Exposiçáo-Default }\end{array}$ & $\begin{array}{c}\text { Valor Aconselhável } \\
\text { Default }\end{array}$ \\
\hline \multicolumn{4}{|l|}{ Comum a todas as rotas } \\
\hline \multirow[t]{2}{*}{ Peso do Corpo } & {$[\mathrm{Kg}]$} & 70 (Adulto) & 70 (Adulto) \\
\hline & & 15 (Criança) & 15 (Criança) \\
\hline Expectativa de Vida & [anos] & 70 & 70 \\
\hline \multicolumn{4}{|l|}{ Ingestáo de Água } \\
\hline Duração da Exposição & [anos] & 30 & 9 \\
\hline Freqüência da Exposição & [dias/ano] & 365 & 350 \\
\hline Razão de Ingestão & [litros/dia] & 2 & 1,4 \\
\hline Biodisponibilidade & {$[\mathrm{mg} / \mathrm{mg}]$} & Especificação Química & Especificação Química \\
\hline \multicolumn{4}{|l|}{ Contato Dermal Durante o Banho } \\
\hline Duração da Exposição & [anos] & 30 & 9 \\
\hline Freqüência da Exposição & [dias/ano] & 365 & 350 \\
\hline Tempo de Exposição & [horas/dia] & 0,333 & 0,12 \\
\hline Area Total da Superficie da Pele & {$\left[\mathrm{cm}^{\wedge} 2\right]$} & 18150 & 18150 \\
\hline Coeficiente de Permeabilidade & [cm/hora] & Especificaçăo Química & Especificação Química \\
\hline \multicolumn{4}{|l|}{ Contato Dermal com o Solo } \\
\hline Duração da Exposição & [anos] & 30 & 9 \\
\hline Freqüência da Exposição & [dias/ano] & 365 & Especifico do Local \\
\hline $\begin{array}{c}\text { Area da Superficie da Pele (braços e } \\
\text { mãos) }\end{array}$ & {$\left[\mathrm{cm}^{\wedge} 2\right]$} & 3120 & 3120 \\
\hline Fator de Aderência & {$\left[\mathrm{mg} / \mathrm{cm}^{\wedge} 2\right]$} & 1,45 & 0,6 \\
\hline Coeficiente de Absorção & {$[m g / m g]$} & Especificação Química & Especificação Química \\
\hline \multicolumn{4}{|l|}{ Ingestão de Solo } \\
\hline Duração da Exposiç̧ão & [anos] & 30 & 9 \\
\hline Frequencia de Contato com o Solo & [dias/ano] & 365 & 350 \\
\hline \multirow[t]{2}{*}{ Razão de Ingestão de Solo } & [mg/dia] & 200 (Criança) & 50 (Criança) \\
\hline & & 100 (Adulto) & 10 (Adulto) \\
\hline Fração de Solo Contaminado & {$[\mathrm{mg} / \mathrm{mg}]$} & 1 & Especifico do Local \\
\hline Biodisponibilidade & {$[\mathrm{mg} / \mathrm{mg}]$} & Especificação Química & Especificação Quimica \\
\hline
\end{tabular}




\subsubsection{Estimativa de Ingresso Diário Crônico e para a Vida Toda}

O ingresso diário crônico é utilizado para avaliação dos efeitos não cancerígenos à exposição, sendo avaliado como segue:

$$
I D C=I D . F E \cdot D E /(365 T M) \quad \text { (equação 09) }
$$

Onde :

$$
\begin{aligned}
& I D C=\text { dose diária crônica absorvida [mg/kg-dia] } \\
& I D=\text { ingresso diário estimado (equações anteriores)[mg/kg-dia] } \\
& F E=\text { freqüência de exposição [dias/ano] } \\
& D E=\text { duração da exposição [anos] } \\
& T M=\text { tempo médio [anos] }
\end{aligned}
$$

Em avaliações de efeitos não cancerigenos $T M$ é igual a $D E$.

O ingresso diário médio considerando a vida inteira (IDM) é utilizado para avaliações de efeitos cancerigenos, estimando-se a média do ingresso diário (pelo periodo ao qual o individuo ficou exposto) ao longo de toda a vida deste indivíduo.

$$
I D M=I D \cdot F E \cdot D E /(365 T M) \quad \text { (equação 10) }
$$

Nestas avaliações de efeitos cancerígenos o tempo médio é igual à vida inteira do indivíduo.

\subsubsection{A Caracterização do Risco}

Envolve a quantificação dos riscos aos receptores potenciais associados à exposição aos compostos químicos de interesse e a descrição destas estimativas de risco, através da integração dos resultados obtidos nas etapas anteriores. A caracterização de risco é realizada para os compostos químicos de interesse e rotas de exposição identificados na formulação do problema como apresentando os maiores potenciais para contribuir em riscos mensuráveis para receptores sensiveis.

\subsubsection{Estimativa do Risco para Efeitos Cancerígenos}

O risco pode ser quantificado como o incremento na probabilidade de um indivíduo desenvolver câncer ao longo da vida. Este excesso no risco incorre das avaliações de exposição a contaminante(s) pelos padrões e rotas citadas 
anteriormente. O risco pode ser quantificado como o produto do ingresso diário ao longo da vida (IDM) pelo fator de potência (FP).

$$
\text { Risco }=F P . I D M \quad \text { (equação 11) }
$$

O risco é um resultado probabilistico, assim um risco de $10^{-6}$ significa o incremento de um caso de câncer a cada um milhão $\left(10^{6}\right)$ de indivíduos como resultado da exposição.

\subsubsection{Estimativa do Risco para Efeitos Não Cancerígenos}

Os riscos para efeitos não cancerigenos são avaliados a partir da premissa de que há um limite de exposição abaixo do qual é incomum um indivíduo sentir os efeitos adversos na saúde. Pode ser caracterizado como a razão entre a dose diária crônica absorvida (IDC - mg/kg.dia) e a dose de referência à exposição crônica especifica do composto (DRf - mg/kg.dia).

$$
Q R=I D C / D R f \quad \text { (equação 12) }
$$

O quociente de risco (QR) não é um risco probabilistico. Quando o valor é maior que um significa que há risco de efeitos adversos. A exposição a mais de um composto que envolva risco significa a soma destes quocientes para cada composto.

A caracterização do risco é um processo com várias incertezas, que vão se acumulando ao longo das etapas anteriores, cujas escolhas de valores invariavelmente tendem para as mais consenvadoras, podendo causar superestimativas de risco no sentido de proteção aos receptores.

\subsubsection{Etapas no Processo de Avaliação Segundo a Metodologia ASTM-RBCA}

A avaliação inicial do sitio consiste na coleta de dados para implementação desta etapa, através da caracterização da fonte, extensão da migração e potencial de exposição e degradação. 


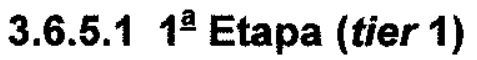

Os parâmetros comparativos desta etapa são os Risk Based Screening Levels - RBSL, valores alvo baseados no risco, que são calculados com base em parâmetros consenadores e tabelas de referência. Estas tabelas são listas de modelos e equações sugeridas pela United States Environmental Protection Agency - USEPA para seleção dos RBSL.

Em todas as situações partem-se da utilização de hipóteses conservadoras para a formação do cenário, com os pontos de exposição localizados na área da fonte e não utilização de parâmetros especificos do sítio. A localização do ponto de exposição na área da fonte implica na desconsideração de mecanismos de transporte e atenuação de contaminantes ou consideração somente de advecção.

À medida que os dados são coletados e os cenários constituídos, deve-se atribuir uma classificação ao sítio e ação resposta inicial, geralmente no sentido de monitoramento do sítio enquanto avançam as investigações e conseqüente atualização da classificação. $A$ ação resposta só envolve remediação no caso de uma fonte primária com exposição aguda.

\subsubsection{2 $2^{\mathrm{a}}$ Etapa (tier 2)}

A partir desta etapa o uso de modelos matemáticos, relativamente simples, de transporte de contaminantes passa a ocorrer de modo efetivo, com a substituição das hipótese conservadoras e genéricas por dados especificos do sítio e o receptor fora da área da fonte.

Nesta etapa, adotam-se como parâmetros comparativos os Site Specific Target Levels - SSTL, que são os valores alvo específicos do local. Os mecanismos de transporte e a distância do receptor à fonte são fundamentais para a estimativa dos valores alvo. Assim, consideram-se advecção, dispersão e pode-se ou não considerar adsorção.

Os SSTL devem ser atingidos para que não ocorram riscos aos receptores. Se o risco no ponto de exposição extrapola o risco admitido, devem-se propor ações que reduzam as concentrações de forma a se atingir o risco admitido para o receptor. 


\subsubsection{3 $3^{\mathrm{a}}$ Etapa (tier3)}

Os SSTL (Valores Alvo Específicos do Sítio) também são utilizados como parâmetros comparativos, mas através do uso de modelos mais refinados, incluindo avaliações probabilisticas e sofisticados modelos de atenuação e transporte, considerando-se também decaimento de primeira ordem com perda de massa. Ocorre um incremento grande de dados específicos do sítio e grau de conservadorismo mais baixo. 


\section{MATERIAIS E MÉTODOS}

Os procedimentos para a avaliação da contaminação $\theta$ do risco na área de estudo, podem ser descritos conforme as seguintes etapas:

\subsection{Levantamento de dados}

\subsubsection{Revisão bibliográfica}

Na busca por informações referentes aos temas abordados neste trabalho, foram consultadas as bibliotecas do Instituto de Geociências da Universidade de São Paulo, da CETESB e endereços eletrônicos de órgãos e institutos nacionais e internacionais de pesquisa e informação através da world wide web. As referências utilizadas estão apresentadas no capítulo de Referências Bibliográficas.

\subsubsection{Inspeção visual}

Em cada evento de monitoramento na área foram realizadas inspeções visuais do local para elaboração e aprimoramento do modelo conceitual da hidrogeologia e geologia locais. Nestas inspeções foram avaliadas as condições geomorfológicas, situação da drenagem local, verificação de possiveis interferências, identificação do tipo de litologia e dos possiveis condicionantes hidrogeológicos. Concomitantemente, entrevistaram-se funcionários da Empresa na busca por informações relevantes ao desenvolvimento do trabalho e caracterização do histórico da contaminação. 


\subsection{Trabalhos de campo}

\subsubsection{Sondagens}

Foram realizadas 21 sondagens através de cavadeira manual e trado mecanizado, de diâmetro externo de $10,16 \mathrm{~cm}$, com amostragem para análise táctilvisual, permitindo uma caracterização geológico-geotécnica da área. Destas, as duas primeiras foram realizadas no intuito de atingir o aqüifero livre para amostragem de água e execução de análises físico-químicas, com posterior fechamento dos furos. As outras dezenove sondagens foram utilizadas para a instalação dos poços de monitoramento.

\subsubsection{Amostragem de Solo}

Efetuaram-se 26 amostragens de solo, com 21 amostras coletadas em junho de 1998 e 05 amostras em fevereiro de 2001. Utilizou-se trado manual de $10,16 \mathrm{~cm}$ de diâmetro, em profundidades em torno de $1 \mathrm{~m}$ na primeira campanha e $0,5 \mathrm{~m}$ na segunda. Em agosto de 1998 foram coletadas cinco amostras de solo contaminado e removido de área da Empresa, disposto em caçambas. Todas as amostras foram acondicionadas em frascos esterilizados e enviadas aos laboratórios para a realização das análises de solo. As amostras de solo foram enviadas para os laboratórios de análises Puriquima Ltda. e Ecolabor Ltda.. A localização dos pontos de amostragem pode ser vista na Figura 03.

\subsubsection{Instalação de Poços de Monitoramento}

Instalou-se um total de dezenove poços de monitoramento (PM) do aqüifero livre na área de estudo, condicionados à existência de interferências de superfície e subsolo, que por vezes impuseram uma localização para os poços diferente da ideal, baseada em modelo hidrogeológico conceitual de fluxo. 
Estes trabalhos foram desenvolvidos em quatro etapas, compreendidas entre junho de 1998 e fevereiro de 2001, a saber: PMs 01 a 06 na primeira etapa (junho de 1998); PMs 07 a 09 na segunda etapa (fevereiro de 1999); PMs 10 a 12 na terceira etapa (abril de 1999) e PMs 13 a 19 na quarta etapa (fevereiro de 2001).

Os poços foram revestidos com tubos geomecânicos, inertes, de diâmetro interno de 5,08 cm e filtro de mesmo material e dimensões, com ranhuras de 0,50 $\mathrm{mm}$, apropriada à granulometria local, para impedir a passagem de material fino particulado. Os espaços anelares entre os tubos e a parede do furo foram preenchidos com pré-filtro de granulometria adequada e tiveram em sua parte logo acima, solo argiloso reposto compactado, selo em bentonita pelotizada e novamente solo reposto compactado, com outro selo sanitário feito por cimento, em sua parte superior. A proteção de boca de poço foi feita por tampa de alumínio rosqueável com cadeado e posterior colocação de uma câmara de ferro, situada próxima do nivel do pavimento. Os perfis descritivos das sondagens e dos poços de monitoramento encontram-se no Anexo 01 e suas localizações na figura 03.

\subsubsection{Planialtimetria}

Todos os poços de monitoramento foram locados em planta através do levantamento das cotas de boca com a utilização de equipamento tipo Estação Total da marca Nikon modelo DTM 410. Outros pontos de referência da área também foram levantados, não se realizando levantamento planialtimétrico da área.

\subsubsection{Amostragem de Água Subterrânea}

Para a amostragem da água dos poços de monitoramento utilizou-se técnica similar à aconselhada pela USEPA (ASTM - D 5903/96) e aquela recomendada pelo laboratório responsável, conforme guia de coletas CETESB (1988). No total, foram realizadas nove campanhas de amostragem, cujas amostras de água foram enviadas para os laboratórios de análises Puriquima Ltda. e Ecolabor Ltda.

Como procedimento padräo, anterior às coletas realizadas em todos os eventos, realizava-se o esgotamento manual dos poços ou retirada de água em 
volume igual a três vezes o volume da coluna d'água nos poços. Os níveis d'água eram medidos antes do esgotamento dos poços e antes da realização das amostragens, que eram efetuadas 24 horas após o esgotamento. As medidas de nivel d'água foram realizadas com medidores elétricos.

As coletas de água foram realizadas com amostradores manuais descartáveis. Consistem em cilindros de plástico que possuem uma válvula de retenção em sua extremidade inferior, que permite a entrada de água no tubo quando da descida do mesmo e retenção quando da sua retirada do poço. São suspensos por cordas de nylon, também descartáveis.

As amostras eram acondicionadas em frascos descartáveis de vidro ou polietileno e mantidas refrigeradas desde a coleta até a análise química, com encaminhamento ao laboratório em prazo nunca superior a 24 horas.

Para a presenvação das amostras para análise dos metais, utilizou-se $\mathrm{HNO}_{3}{ }^{-}$, no intuito de rebaixar o $\mathrm{pH}(<3)$ e evitar a precipitação de hidróxido férrico seguida pela adsorção dos metais, mantendo-se a estabilidade das amostras.

Durante as campanhas de amostragem foram obtidos alguns resultados, de parâmetros físicos da água, como temperatura, $\mathrm{pH}$, condutividade elétrica e Eh. Estas medidas foram efetuadas no momento de coleta de cada amostra para cada poço, em amostra sem preservação, distinta daquela destinada para o laboratório. Entre uma medida e outra, o equipamento era limpo com água deionizada, para evitar qualquer interferência entre os resultados. Para a medição destes parâmetros foram utilizados os equipamentos da marca Digimed Ltda., modelo DM2.

\subsubsection{Slug tests}

Os Slug Tests (Hvorslev, 1951) são utilizados em hidrogeologia para a determinação da condutividade hidráulica de um meio poroso, no qual o(s) intervalo(s) testado(s) corresponde(m) àquele(s) localizado(s) junto ao(s) filtro(s). ensaio consiste em introduzir ou retirar um volume sólido conhecido dentro do poço, de modo que o nivel d'água (NA) dentro do poço seja elevado ou rebaixado instantaneamente, num volume deslocado conhecido equivalente à adição ou retirada instantânea de água do aqüifero. Ao monitorar-se o NA obtém-se uma curva 
de rebaixamento ou recuperação do mesmo em função do tempo. Desta curva são extraídos parâmetros que, junto com características geométricas do poço, fornecem a condutividade hidráulica do intervalo. Foram realizados quatro ensaios nos poços instalados, cujos resultados encontram-se no Anexo 02.

\subsection{Trabalhos de laboratório}

\subsubsection{Análises de Solo}

Analisaram-se as concentrações de cloreto nas primeiras 21 amostras de solo da área e nas cinco amostras de solo removido para caçambas. Na última coleta de solo, com cinco amostras, analisaram-se os metais pesados $\mathrm{Cu}, \mathrm{Pb}$, e $\mathrm{Zn}$, segundo as normas American Water Works Association (AWWA) - American Public Health Association (APHA) - Standard Methods for Examination of Water and Wastewater $20^{2}$ edição.

\subsubsection{Análises de Água}

Analisaram-se as concentrações de cloreto nos cinco primeiros eventos de monitoramento e para os metais $\mathrm{Cu}, \mathrm{Pb}$, e $\mathrm{Zn}$ nos quatro últimos eventos, conforme as normas American Water Works Association (AWWA) - American Public Health Association (APHA) - Standard Methods for Examination of Water and Wastewater $20^{a}$ edição.

\subsection{Interpretação dos Resultados}

Os niveis d'água (NA) nos poços de monitoramento foram medidos e os valores obtidos cruzados com os dados de cota de boca e plotados em mapa, para a obtenção da potenciometria do local. Posteriormente traçaram-se as isolinhas dos niveis d'água, gerando o mapa potenciométrico. Os mesmos dados foram utilizados 
na determinação dos gradientes hidráulicos.

Para interpretação dos resultados das análises químicas de solo, as concentrações obtidas foram comparadas com Valores de Referência estabelecidos pela CETESB através do documento "Estabelecimento de Valores Orientadores para Solos e Águas Subterrâneas no Estado de São Paulo - Tabela Final Revisada (Relatório Final, 2001 no prelo)", que propõe o denominado "Sistema RAl".

Os resultados das análises químicas das amostras de água subterrânea foram comparados com os valores estabelecidos através da Portaria 1469 do Ministério da Saúde, de Dezembro de 2000, que substitui a Portaria 36. Comparativamente, estão apresentados os limites propostos pelo Sistema RAI da CETESB.

Estes resultados estão plotados em diagramas de Eh-pH, para cloreto e para os metais (cobre, chumbo e zinco), onde estão apresentados com as medidas de campo para os poços amostrados e referentes a cada evento de monitoramento, cujos resultados indicam seus respectivos campos de estabilidade em água subterrânea.

\subsection{Avaliação de Risco}

O procedimento utilizado na avaliação de risco seguiu a metodologia proposta pelo programa de suporte desenvolvido pelo American Petroleum Institute (API), denominado "American Petroleum Institute Exposure and Risk Decision Support System - API-DSS", baseado na metodologia RBCA (Risk Based Corrective Action).

A avaliação de risco do local realizou-se em segunda etapa (Tier 2), em função dos dados disponíveis e limitações do modelo adotado, considerando-se o metal chumbo como contaminante de interesse. As vias de exposição consideradas foram o contato dermal e ingestão de água subterrânea e solo contaminados. Para as simulações de transporte utilizou-se o modelo AT123D - Analytical Transport One, Two, Three Dimensions.

O API-DSS consiste em quatro fases principais integradas, que resultam numa avaliação dos riscos provocados pela exposição ao contaminante que seja 
cientificamente defensável. São elas: Desenvolvimento do cenário de risco, comportamento (destino e transporte) do contaminante, ingresso de contaminante e estimativa do risco.

\subsubsection{Desenvolvimento do cenário de risco}

Nesta fase, para a elaboração do modelo conceitual do cenário de risco, três tipos de dados são definidos: contaminante de interesse, rotas de exposição e estimativa de concentração no receptor.

\subsubsection{Contaminante de interesse}

O programa contém uma lista de compostos, devendo-se selecionar o contaminante de interesse (ou contaminantes até um máximo de cinco), permitindo também a inclusão de outros contaminantes não pertencentes à lista préestabelecida.

O processo de seleção de contaminante de interesse pode ser brevemente delineado a partir das seguintes características observadas sobre compostos analisados:

- positivamente detectado em pelo menos uma amostra;

- detectado em níveis significativamente elevados, acima de valores de concentrações naturalmente presentes;

- associação histórica com o local ou transformação química de produtos comprovadamente presentes.

\subsubsection{Rotas de exposição}

A partir da avaliação do cenário de risco, seis rotas podem ser avaliadas, a saber: ingestão de água; contato dermal durante o banho; inalação durante o banho; ingestão de solo; contato dermal com solo e inalação de gases do solo.

$A(s)$ rota(s) deve(m) ser selecionada(s) de acordo com o tipo e localização do receptor, considerando todas as rotas às quais o receptor possa estar exposto. As rotas de interesse para o trabalho estão detalhadas no item 3.6.3.1. 


\subsubsection{Método de estimativa de concentração no receptor}

Os dados necessários para a estimativa do risco em um local dependem do modelo conceitual desenvolvido. Assim, os dados dependem do tipo e localização do receptor, do meio contaminado, do método de estimativa de concentração no receptor e as rotas de exposição selecionadas.

De acordo com a(s) rota(s) selecionada(s) deve-se adotar um modelo que contemple a avaliação para o(s) meio(s) especificamente, que pode ser um modelo de transporte ou concentração especifica para o ponto considerado, que serão detalhados no próximo item.

\subsubsection{Destino e Transporte do Contaminante}

O APIDSS permite ao usuário especificar diretamente as concentrações de contaminante no receptor para o cálculo do risco ou a simulação de transporte para a estimativa destas concentrações. Neste trabalho foram consideradas concentrações em água subterrânea e em solo para as avaliações de risco, conforme as rotas de interesse.

Em solo foram utilizadas concentrações especificas, ou seja, resultados obtidos em análises químicas de amostras do local. Para água subterrânea, utilizouse o modelo de transporte AT123D para simulação das concentrações nos pontos receptores, a partir de informações especificas da área como fonte de contaminação, zona saturada e distância do receptor.

O AT123D é um modelo analítico geral, transiente, utilizado para estimar o transporte uni, bi ou tridimensional de rejeitos diversos (aquosos, dissolvidos, etc) em um sistema poroso na zona saturada. Foi desenvolvido por Yeh em 1981, que tem sido amplamente usado como primeira aplicação em várias situações relacionadas à avaliação de risco de locais com compostos perigosos.

Este modelo soluciona a equação diferencial de balanço de massa (advecção - dispersão) que descreve o comportamento de um contaminante na zona saturada. O fluxo de água subterrânea é assumido como constante e unidimensional na direção decrescente do gradiente hidráulico. O processo de simulação deste modelo 
pode incluir: Dispersão tridimensional (longitudinal, lateral e vertical); Advecção uniforme unidimensional; Adsorção linear; Decaimento de primeira ordem (por biodegradação ou outro processo químico de transformação).

Todos os parâmetros intrínsecos do aqüifero são considerados (densidade aparente, permeabilidade intrínseca, condutividade hidráulica, porosidade, etc) e o aqüífero assumido como homogêneo e isotrópico, podendo ser considerado como infinito ou finito lateral e verticalmente.

A fonte pode ser assumida para injeções de massa instantânea, constante ou pulsante, com capacidade para simular a geometria da fonte tridimensionalmente, através dos eixos de coordenadas $x, y$ e $z$, definindo condições de contorno iniciais, caracterizando a forma da fonte como um ponto, linha, área (plana) ou volume.

O AT123D pode ser utilizado para estimar concentrações em função do tempo em qualquer local especificado por diferentes valores de $x, y$ e $\mathrm{z}$ coordenadas de tempo.

\subsubsection{AT123D - Sistema de Coordenadas e Configuração da Fonte}

O modelo utiliza um sistema de coordenadas cartesianas para descrever a fonte e a localização dos pontos de monitoramento. O eixo x ou longitudinal é a direção da velocidade de fluxo unidimensional no aqüifero. $O$ eixo z é a direção vertical medida positivamente para baixo e com valor zero no nivel d'água. $A$ outra direção horizontal ou transversal é representada pelo eixo $y$. Assim, o modelo AT123D permite oito diferentes configurações de fonte, a saber: pontual; linear paralela ao eixo $x ;$; linear paralela ao eixo $y$; ; linear paralela ao eixo z; em área perpendicular ao eixo $x$; em área perpendicular ao eixo $y$; em área perpendicular ao eixo z e volumétrica.

No API-DSS, um dos pontos de coordenada da fonte é sempre a origem do sistema de coordenadas e o usuário é solicitado a entrar com as dimensões da fonte nos eixos $x, y$ e z. Assim, para uma fonte pontual o valor de entrada deve ser zero para as três dimensões. Para uma fonte linear na direção $x$, somente a dimensão $x$ não será zero, com as dimensões y e z sendo zero. Para uma fonte plana, perpendicular ao eixo $x$, o valor de entrada para o eixo $x$ deve ser zero $e$ as dimensões da fonte para os eixos y e z. Para uma fonte volumétrica, os três valores 
de entrada devem ser diferentes de zero.

Após a configuração da fonte é necessário definir a massa de contaminante da fonte. O modelo permite três diferentes opções de liberação de massa para o aqüífero: instantânea, contínua e de duração finita, onde o usuário pode especificar qualquer um destes três tipos e qualquer uma das oitos formas.

Para a opção de fonte instantânea, o usuário especifica a massa e volume da fonte. A massa de contaminante é assumida para ser instantaneamente liberada iniciando-se a simulação (tempo = zero). Esta opção pode ser aplicada quando uma massa conhecida de contaminante está presente na zona saturada e não há expectativa de ocorrer mais liberação a partir da zona insaturada (por exemplo, após remediação desta zona insaturada). Para vazamentos em tanques ou outra descarga conhecida na zona saturada, o usuário pode ter uma estimativa da taxa de liberação de massa para a zona saturada. Neste caso, as segunda ou terceira opções de fonte podem ser usadas para especificar uma massa conhecida, que pode ser constante durante todo o tempo de simulação ou por período de tempo (pulso) menor do que o tempo de simulação, cuja taxa é zero fora do periodo do pulso.

\subsubsection{AT123D - Características Básicas do Modelo e sua Aplicabilidade}

O modelo baseia-se nas seguintes hipóteses simplificadas:

$>$ O modelo assume que um dos pontos da fonte é sempre a origem, assim, somente as dimensões da fonte em cada direção são necessários como dados de entrada;

$>\quad O$ modelo estima as concentrações médias para um receptor, com localização ao longo dos eixos x e y e média de dez intervalos para o eixo z;

$>\quad$ Consideram-se somente tempos anuais nas saídas de dados, com limite máximo de 100 anos;

$>$ A zona saturada é assumida como homogênea, isotrópica e de geometria uniforme, ou seja, com espessura e largura uniformes;

$>$ A superfície potenciométrica é assumida como estável sem flutuações;

$>$ A direção de fluxo é uniforme, unidimensional e constante (steady state);

$>\quad$ O decaimento do contaminante é considerado de primeira ordem e a 
adsorção é considerada linear;

$>$ Concentrações nas fases liquida e sólida do aqüifero são sempre assumidas em equilibrio;

$>$ O modelo simula somente o transporte de fase dissolvida, não sendo aplicável para simular transporte de produto livre.

\subsubsection{AT123D - Estimativa de concentração média em poço receptor}

Os poços possuem filtros em dimensões geralmente limitadas a um trecho da zona saturada. Assim, a concentração de um contaminante amostrada ou mesmo bombeada de um poço é na realidade uma concentração média da água ao redor do filtro do poço, vertical e horizontalmente, não representando precisamente a concentração no aqüifero. O modelo não soluciona esta dificuldade, entretanto emprega um método de aproximação para estimar concentrações médias, dividindo em dez intervalos iguais ao longo do filtro, para cálculo de uma média aritmética da concentração no poço. Este método assegura pesos iguais a todos os intervalos entre o topo e a base do filtro, porém, não considera água extraída de trechos abaixo ou acima do filtro.

As tabelas com dados de entrada do modelo estão apresentadas no capitulo de modelagem de transporte.

\subsubsection{Ingresso de Contaminante}

Esta etapa estima o ingresso de contaminante no organismo do receptor para cada rota de exposição selecionada. A concentração no receptor pode ser obtida através da simulação de transporte para sua estimativa ou especificar diretamente a concentração do contaminante no receptor.

Este ingresso é estimado a partir da entrada de dados de exposição, parâmetros químicos e de toxicidade adotados. Consideraram-se sempre dois grupos de dados para estimativa do ingresso, um mais conservador e um mais usual. A partir das equações mostradas no item 3.6.3.1, o programa calcula os ingresso de contaminante para as respectivas rotas. 


\subsubsection{Estimativa do Risco}

O cálculo do risco é o passo final no trabalho de avaliação de risco, onde informações da toxicidade dos compostos é combinada com as estimativas de ingresso diário do contaminante para o cálculo do risco ao(s) receptor(es).

De fato, após a entrada de dados para estimativa de ingresso de contaminante, o programa executa o cálculo do risco através das equações mostradas no item 3.6.4 ao mesmo tempo em que calcula o ingresso e apresenta os resultados numa mesma saida de resultados. 


\section{RESULTADOS}

\subsection{Localização da Área}

A Empresa situa-se à margem da Rodovia Raposo Tavares, na altura do km 29, sentido Interior, na Região Metropolitana de São Paulo, no município de Cotia. O acesso ao local ocorre através da Rodovia Raposo Tavares.

É uma área com ocupação antrópica, com uso e ocupação do solo residencial e industrial, porém com extensa exposição de solo e áreas verdes, apresentando pequena porcentagem de solo impermeabilizado, principalmente na pavimentação das ruas.

A jusante da área há o rio Cotia, que neste trecho é caracterizado pela CETESB como classe 3 (Decreto Estadual 10755/77), ou seja, necessita de tratamento convencional para poder destinar-se ao consumo humano.

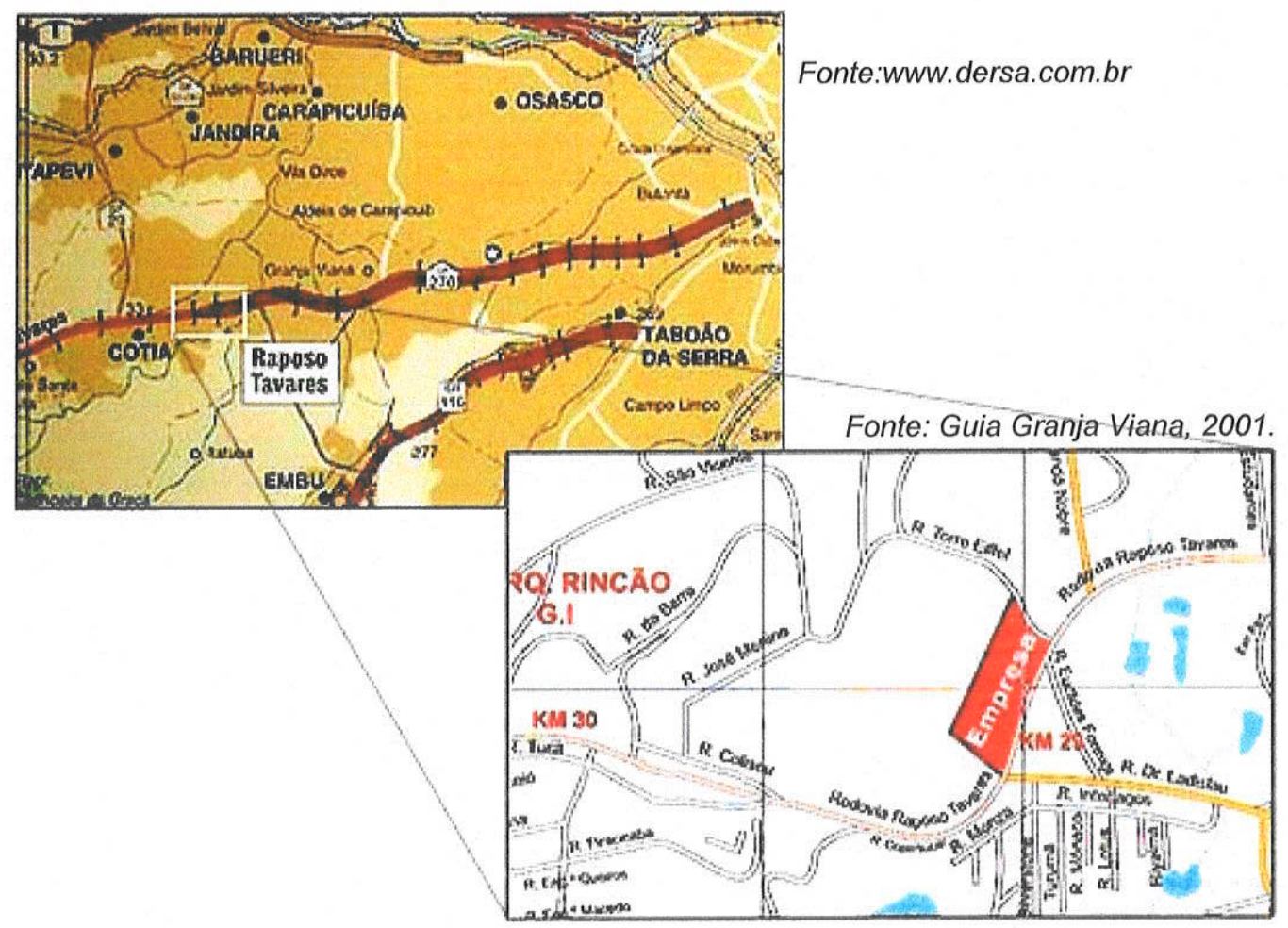

Figura 02 - Mapa de Localização da Área (sem escala). 


\subsection{Histórico}

Em 02 de janeiro de 1998 a Empresa observou gotejamento de ácido clorídrico através de uma flange na saída de um tanque de armazenamento com capacidade para $50.000 \mathrm{~L}$, que no momento encontrava-se cheio. A equipe de manutenção providenciou a transferência do ácido para outros tanques, restando $10.000 \mathrm{~L}$ de ácido no referido tanque, conseguindo também estancar o gotejamento, conforme relatado à CETESB.

Entretanto, na manhã seguinte, obsenvou-se que estava escorrendo ácido em área de jardim interno à empresa e atingindo vias públicas, inclusive trecho lateral da Rodovia Raposo Tavares e o rio Cotia. Neste momento, providenciou-se o esgotamento de um tanque da decapagem para a estação de tratamento de efluentes enquanto eram providenciados caminhões para o armazenamento do ácido e colocação de cal sobre as áreas afetadas. O ácido foi acondicionado em caminhão tanque apropriado, totalizando $8.000 \mathrm{~L}$ e notou-se que a flange havia rachado em toda sua extensão.

Foram colocados cerca de $950 \mathrm{~kg}$ de cal na área atingida e posteriormente removido através de raspagem do solo de áreas interna e externa, com o material armazenado em caçamba estocada internamente, num total aproximado de 2.500 $\mathrm{kg}$. Embora medidas emergenciais tenham sido tomadas imediatamente, parte do produto derramado infiltrou no solo, gerando uma contaminação das águas subterrâneas no local.

Além disso, como agravante, há um histórico de transbordamento por antigo sistema de tratamento de efluentes domésticos e industriais (Fonte A), como potencial fonte de contaminação de solo e água subterrânea, que veio a assumir importância maior no decorrer do estudo do que o vazamento de ácido.

A partir deste evento, a CETESB vem solicitando mais detalhes do local, como o mapeamento da pluma de contaminação e seu avanço e medidas para a recuperação da área atingida. Para o atendimento destas solicitações da CETESB foram realizados os três primeiros eventos de instalação de poços de monitoramento (PMs 01 a 12), sendo o quarto e último evento basicamente para substituir poços danificados. 


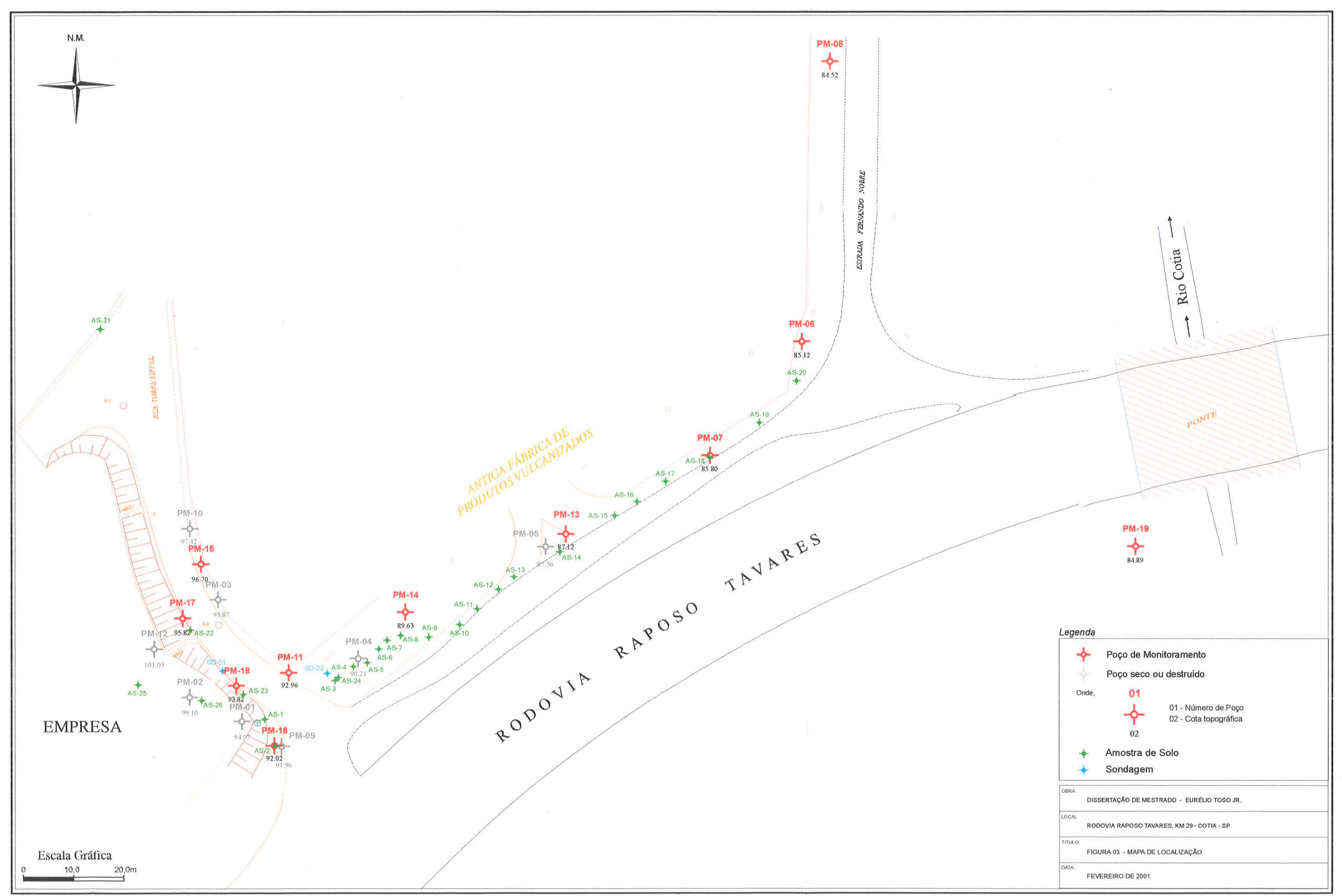


Alguns resultados de análises solicitados pela CETESB indicaram presença de alguns metais, não analisados anteriormente, que deve ter ocorrido pelo fato do decréscimo do $\mathrm{pH}$ devido ao vazamento ter solubilizado e mobilizado metais anteriormente presentes no solo. Ao final de 1999 foram solicitadas análises químicas para os metais chumbo, cobre e zinco, que poderiam ocorrer em subsolo devido aos efluentes industriais da empresa. Assim, os monitoramentos e avaliações realizados em 2000 e 2001 passaram a contemplar os metais citados, bem como avaliação de risco em função da contaminação verificada.

Os resultados obtidos ao longo dos estudos indicaram uma segunda área fonte de contaminação (Fonte B), com concentrações mais altas do que a primeira, a partir de uma fábrica de produtos vulcanizados, vizinha a jusante e desativada há cinco anos. Assim, tornou-se fundamental para o estudo a inclusão desta área para a interpretação dos resultados e simulações de transporte.

\subsection{Caracterização geológico-geotécnica}

A bacia hidrográfica do Rio Cotia está alojada sobre rochas do embasamento cristalino, Complexo Pilar, de idade proterozóica, onde se diferenciam gnaisses e xistos, ocorrendo ainda pequenas manchas de rochas sedimentares terciárias da Formação São Paulo e sedimentos aluvionares quaternários (SABESP,1997).

Os gnaisses, que ocorrem na área de estudo, têm geralmente matriz fina a média, cinza e escura, foliada de composição granodiorítica a tonalítica, com hornblenda, biotita e megacristais de feldspatos alcalinos. A foliação tem direção nordeste e apresenta dobramentos localizados (SABESP,1997).

A alteração destas rochas geralmente resulta na formação de solos argilosos e micáceos, sendo que o teor de areia e silte varia em conseqüência do teor de quartzo e feldspato das rochas. Assim, predominam termos argilosos e siltosos nas porções mais micáceas, termos argilo-arenosos e areno-argilosos nas porções quartzo-feldspáticas. A espessura dos solos é variável e controlada pela topografia podendo apresentar espessuras de alguns metros nos topos e ser menor que 0,5 $\mathrm{m}$ nas encostas com declividades mais acentuadas (SABESP,1997). 
Para a caracterização da geologia local, foram analisados afloramentos presentes nas imediações da área de estudos, mas principalmente baseado em observações táctil-visuais de amostras retiradas durante a realização das sondagens, observando-se o total predomínio dos solos de alteração de rocha (ou solos residuais) provenientes da alteração de rochas gnáissicas do embasamento cristalino.

Os solos encontrados na área alternam-se predominantemente entre siltes argilo-arenosos, com variações granulométricas locais devido à maior ou menor presença das frações arenosas, micáceos, eventualmente com fragmentos milimétricos de rocha e argilas silto-arenosas, micáceas com intercalações decimétricas a métricas de níveis areno-argilosos. Os perfis descritivos das sondagens para instalação dos poços de monitoramento estão no Anexo 01.

O solo superficial que ocorre na área, caracterizado nas descrições como aterro, é constituído por material argilo-arenoso, com pedregulhos pequenos, poroso, marrom.

\subsection{Caracterização hidrogeológica local}

Para a caracterização da hidrogeologia da área, além do levantamento de dados em campo, foram instalados dezenove poços de monitoramento (PM), cuja distribuição em planta está apresentada na figura 03. Estes poços foram utilizados com a finalidade de se obter dados de potenciometria, gradiente hidráulico, condutividade hidráulica e fluxo subterrâneo no aqüifero livre, bem como distribuição da contaminação em água subterrânea, de acordo com o modelo hidrogeológico conceitual elaborado durante levantamentos de campo.

Os trabalhos de monitoramento do aqüifero livre tiveram início em junho de 1998, a partir da instalação dos PMs 01 a 06, estendendo-se ao longo de oito eventos de monitoramento e quatro eventos com instalação de poços, sendo o último em fevereiro de 2001, com a instalação dos PMs 13 a 19.

A partir das medidas dos níveis d'água estabilizados e das cotas planialtimétricas dos respectivos poços, obtidas nos levantamentos topográficos da 
área, foram confeccionados os mapas potenciométricos da área relativos aos eventos de monitoramento. Em função da não obtenção de dados nos poços secos e/ou danificados em alguns eventos, optou-se pela elaboração de mapas potenciométricos somente para os eventos com suficiência de dados, uma vez que há eventos com apenas três níveis d'água estabilizados, insuficientes para a geração de mapa potenciométrico representativo. Assim, elaboraram-se mapas referentes aos eventos de fevereiro de 1999 e fevereiro de 2001 (Figuras 04 e 05).

A interpretação da potenciometria na área constata um padrão para as linhas de fluxo subterrâneo predominantemente condicionado pela topografia local, orientado a partir das cotas altas (norte-noroeste) para as cotas baixas (sudesteleste), com direção inicial noroeste-sudeste sentido sudeste, rumo a um vale local a pouca distância e paralelo à Rodovia Raposo Tavares, quando ocorre inflexão do fluxo assumindo direção aproximada WSW-ENE, rumo ao rio Cotia.

A superfície potenciométrica do aqüifero freático (NA) na área de estudo está situada entre as cotas arbitrárias mínima e máxima 80,91 m (PM-08 em fevereiro de 2001) e 92,15 m (PM-02 em junho de 1998), entretanto, a máxima diferença entre niveis paras um mesmo evento é de 10,63 m (junho de 1998). A zona não saturada possui espessura variando entre $1,70 \mathrm{~m}$ e $8,50 \mathrm{~m}$, conforme último monitoramento.

A execução de terraplenagem através de obras de corte e aterro para implantação da empresa e arruamento do bairro, geraram modificações geomorfológicas locais e de uso e ocupação da área, que interferem na potenciometria de modo local e distinto, através da geração de duas estruturas importantes.

Estas estruturas são as áreas aterradas para a construção dos logradouros adjacentes à empresa, sendo o talude situado a leste da empresa e as vias pavimentadas adjacentes à Empresa (rua Torre Eiffel) a primeira estrutura. A via de acesso à rodovia a partir da Estrada Fernando Nobre e Rodovia Raposo Tavares é a segunda. Impermeabilizações de superficie normalmente originam um rebaixamento do nivel freático, causando um decréscimo na taxa de recarga natural, porém em locais próximos às bordas de áreas impermeabilizadas, pode haver uma elevação local do NA. 


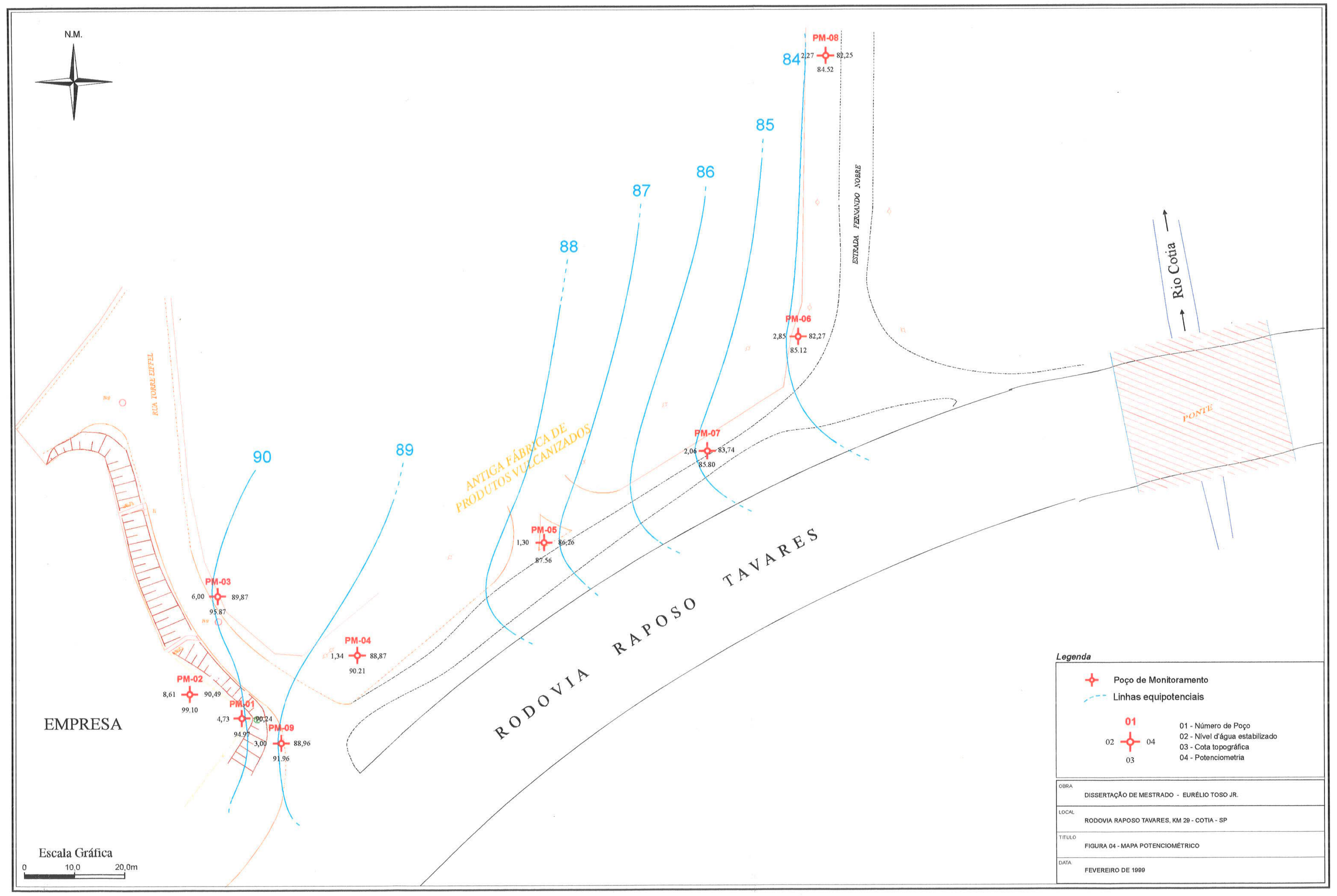




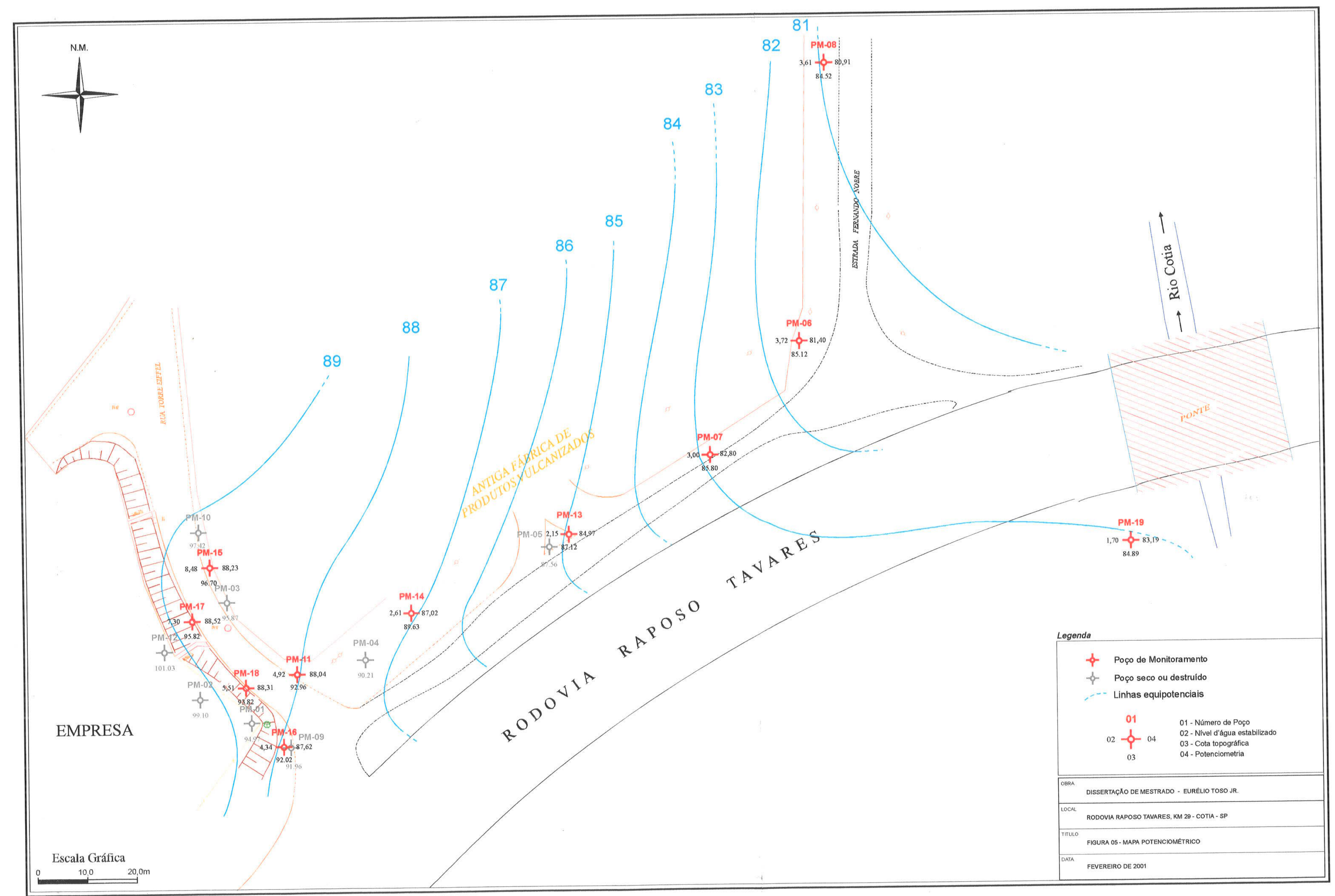


Considerações com relação ao regime de fluxo da água subterrânea indicaram que a presença destas estruturas condicionam o fluxo da água subterrânea ao longo do trecho inicial da rua Torre Eiffel e principalmente ao longo da via de acesso à rodovia, como pode ser observado nos mapas potenciométricos (Figuras 04 e 05).

A estimativa do gradiente hidráulico mais significativo para a área, efetuada a partir dos mapas potenciométricos elaborados, considerou o gradiente que condiciona o movimento das plumas, ou seja, o gradiente no trecho inicial da rua Torre Eiffel e ao longo da via paralela à rodovia Raposo Tavares, caminho preferencial do fluxo no local, em função das razões expostas acima. Assim, o gradiente para cálculo de velocidade de fluxo subterrâneo calculado é de 4,6 \% entre o PM-18 e o PM-07 e de $4 \%$ entre o PM-07 e o rio Cotia, considerados em todas as simulações de transporte, desconsiderando gradientes pontuais ou de menor escala.

No último evento de monitoramento e instalação de poços, em fevereiro de 2001, dos 12 (doze) poços de monitoramento pré-existentes no local, quatro poços apresentavam presença de água (PMs 06,07, 08 e 11), cinco ausência de água (PMs 01, 02, 03, 10 e 12) e três haviam sido destruidos (PMs 04, 05 e 09). Estes poços danificados e secos condicionaram a instalação de seis dos novos poços instalados nesta fase (PMs 13 a 18).

A Empresa possui um poço instalado no aqüifero livre, $20 \mathrm{~m}$ a montante (oeste) do PM-02, a partir do qual retira água para utilização em processos produtivos na área industrial. Não há informações disponíveis de freqüência de uso, regime de bombeamento, nem sequer dados construtivos do poço.

Este poço é a razão assumida para que os PMs 01, 02 e 12 estejam secos. Os dados de nível d'água estabilizado e potenciometria permitem observar a influência deste poço nos PMs 01 e 02, principalmente no PM-02. Cabe ressaltar que a medida de NA de junho de 1998 para o PM-01 parece inconsistente.

Os dados de nível d'água estabilizados e a potenciometria dos poços de monitoramento estão apresentados nas tabelas abaixo. 
Tabela 02 -Medidas de níveis d'água obtidos durante os eventos de monitoramento, entre junho de 1998 e fevereiro de 2001.

\begin{tabular}{|c|c|c|c|c|c|c|c|c|}
\hline \multirow{3}{*}{ Poģo } & \multirow{3}{*}{$\operatorname{Cota}(m)$} & \multicolumn{7}{|c|}{ Nivel D'água Estabilizado $(m)$} \\
\hline & & \multicolumn{7}{|c|}{ Data de Evento de Monitoramento } \\
\hline & & Jun / 98 & Fov $/ 99$ & Mai $/ 99$ & $\begin{array}{l}\text { Jan } / \\
2000\end{array}$ & $\begin{array}{c}\text { Abrill } \\
2000\end{array}$ & $\begin{array}{l}\text { Jun } / \\
2000\end{array}$ & $\begin{array}{l}\text { Fev } 1 \\
2001\end{array}$ \\
\hline$P M-01$ & 94,97 & 9,70 & 4,73 & - & 7,12 & ** & ** & ** \\
\hline$P M-02$ & 99,10 & 6,95 & 8,61 & - & 9,82 & ** & ** & ** \\
\hline$P M-03$ & 95,87 & 7,63 & 6,00 & - & $* *$ & ** & ** & ** \\
\hline$P M-04$ & 90,21 & 3,50 & 1,34 & - & * & $\star$ & * & * \\
\hline$P M-05$ & 87,56 & 3,30 & 1,30 & - & * & $\stackrel{*}{*}$ & ${ }^{\star}$ & * \\
\hline$P M-06$ & 85,12 & 3,60 & 2,85 & - & 3,73 & 3,66 & 3,72 & 3,72 \\
\hline$P M-07$ & 85,80 & $* * *$ & 2,06 & - & 3,80 & 3,22 & 3,63 & 3,00 \\
\hline$P M-08$ & 84,52 & $* * *$ & 2,27 & - & 3,13 & 4,15 & 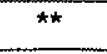 & 3,61 \\
\hline$P M-09$ & 91,96 & $* * *$ & 3,00 & - & * & * & $*$ & * \\
\hline$P M-10$ & 97,42 & $\star * *$ & $* * *$ & 8,58 & $* *$ & ${ }^{* *}$ & $* *$ & $\star \star \star *$ \\
\hline$P M-11$ & 92,96 & $\star * *$ & $* * *$ & 4,27 & 4,84 & 4,98 & 5,42 & 4,92 \\
\hline$P M-12$ & 100,84 & $\star * * *$ & $* * *$ & 11,43 & ** & ** & ** & ** \\
\hline$P M-13$ & 87,12 & $* \star *$ & $\star \star * *$ & $* * *$ & $\star * \star *$ & $\star * \star *$ & $\star \star \star \star$ & 2,15 \\
\hline$P M-14$ & 89,63 & *** & $\star \star \star$ & $* \star \star$ & $\star \star \star$ & $\star * *$ & $\star * * \star$ & 2,61 \\
\hline$P M-15$ & 96,71 & $* * *$ & $* * *$ & $\star \star \star \star$ & *** & $* \star * \star$ & $\star * * *$ & 8,48 \\
\hline$P M-16$ & 92,02 & $\star \star \star$ & $\star * * *$ & $\star \star \star \star$ & $\star \star \star \star$ & $\star \star \star \star$ & $* * *$ & 4,34 \\
\hline$P M-17$ & 95,82 & *** & $\star \star * *$ & $\star \star \star \star$ & $* * \star$ & $\star * \star$ & $* \star \star *$ & 7,30 \\
\hline$P M-18$ & 93,82 & $\star * *$ & $\star * *$ & $* * *$ & $* * *$ & *** & $\star \star \star \star$ & 5,51 \\
\hline$P M-19$ & 84,89 & $k * *$ & $* * *$ & $* * *$ & $\star \star * *$ & $\hbar * *$ & $\star * *$ & 1,70 \\
\hline
\end{tabular}

* Poço danificado; ** Poço seco; *** Poço ainda não instalado 
Tabela 03 - Potenciometria obtida durante os eventos de monitoramento, entre junho de 1998 e fevereiro de 2001.

\begin{tabular}{|c|c|c|c|c|c|c|c|c|}
\hline \multirow{3}{*}{ Poģo } & \multirow{3}{*}{$\operatorname{Cota}(m)$} & \multicolumn{7}{|c|}{ Potenciometria } \\
\hline & & \multicolumn{7}{|c|}{ Data de Evento de Monitoramento } \\
\hline & & Jun / 98 & Fov $/ 99$ & Mai /99 & $\operatorname{Jan}_{2000}$ & $\begin{array}{c}\text { Abril/ } \\
2000\end{array}$ & $\begin{array}{l}\text { Jun / } \\
2000\end{array}$ & $\begin{array}{l}\text { Fev } \\
2001\end{array}$ \\
\hline$P M-01$ & 94,97 & 85,27 & 90,24 & - & 87,85 & $* *$ & ** & ** \\
\hline$P M-02$ & 99,10 & 92,15 & 90,49 & - & 89,28 & ** & ** & *** \\
\hline$P M-03$ & 95,87 & 88,24 & 89,87 & - & ${ }^{\star \star}$ & ** & ** & ** \\
\hline$P M-04$ & 90,21 & 86,71 & 88,87 & - & * & * & * & * \\
\hline$P M-05$ & 87,56 & 84,26 & 86,26 & - & * & ${ }^{*}$ & * & * \\
\hline$P M-06$ & 85,12 & 81,52 & 82,27 & - & 81,39 & 81,46 & 81,40 & 81,40 \\
\hline$P M-07$ & 85,80 & $\star \star \star \star$ & 83,74 & - & 82,00 & 82,58 & 82,17 & 82,80 \\
\hline$P M-08$ & 84,52 & $\star \star \star \star \star$ & 82,25 & - & 81,39 & 80,37 & ** & 80,91 \\
\hline$P M-09$ & 91,96 & $* * \star$ & 88,96 & - & $*$ & $*$ & * & * \\
\hline$P M-10$ & 97,42 & 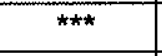 & $* * *$ & 88,84 & ** & $* *$ & 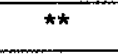 & 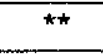 \\
\hline$P M-11$ & 92,96 & $* \star *$ & $\star \star \star \star$ & 88,69 & 88,12 & 87,98 & 87,54 & 88,04 \\
\hline$P M-12$ & 100,84 & $* * *$ & $* * *$ & 89,41 & $* *$ & $\star k$ & ${ }^{* *}$ & $* *$ \\
\hline$P M-13$ & 87,12 & $\star \star \star$ & $* * *$ & *** & $* \star \star \star$ & $\hbar \star \star *$ & $\star \star \star \star$ & 84,97 \\
\hline$P M-14$ & 89,63 & $* \star \star$ & $\star * \star \star$ & $\star \star \star \star$ & *** & $\star \star \star \star$ & 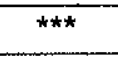 & 87,02 \\
\hline$P M-15$ & 96,71 & $* * *$ & $* \star *$ & k** & 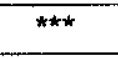 & $* * *$ & $* * *$ & 88,23 \\
\hline$P M-16$ & 92,02 & $\star \star \star *$ & $\star \star \star \star$ & $* * *$ & $\star \star \star \star *$ & $* * *$ & $* * *$ & 87,62 \\
\hline$P M-17$ & 95,82 & $\star \star * *$ & $* * *$ & $\star \star \star \star$ & $\star * *$ & $* * *$ & $* * *$ & 88,52 \\
\hline$P M-18$ & 93,82 & $\star \star \star \star$ & $* \star \star \star$ & $\star * * *$ & $\star \star \star *$ & $\star \star \star *$ & $* \star \star \pi$ & 88,31 \\
\hline$P M-19$ & 84,89 & $\star \star \star \star$ & $\star \star \star \star$ & *** & $\star \star \star \star$ & $\star \star \star \star$ & $* \star *$ & 83,19 \\
\hline
\end{tabular}

* Poço danificado; ** Poço seco; *** Poço ainda não instalado

\subsubsection{Condutividade hidráulica}

Para a determinação da condutividade hidráulica $(K)$ em campo, adotou-se o ensaio denominado Slug Test (Hvorslev, 1951), conforme procedimento descrito no item 4.2.6. Os ensaios foram realizados em fevereiro de 1999 no PM-06 e em fevereiro de 2001 nos PMs 13, 14 e 18, na tentativa de se obter as condutividades hidráulicas ao longo do todo o trecho estudado. A partir da aplicação da equação 10 a seguir, obtêm-se os valores de condutividade hidráulica (K): 


$$
K=\frac{r^{2} \ln (L / R)}{2 L T_{0}} \quad \text { (equação 13) }
$$

Onde :

Ké a Condutividade Hidráulica $[\mathrm{cm} / \mathrm{s}]$

$r$ é o raio do revestimento [cm]

$R$ é o raio do filtro $[\mathrm{cm}]$

Lé o comprimento do filtro [cm]

$T_{0}$ é o tempo que a água leva para atingir $37 \%$ da variação inicial [s]

A tabela 04 mostra o evento, o poço e a condutividade hidráulica obtida através dos ensaios, cujos resultados completos estão apresentados no Anexo 02.

Tabela 04 - Valores de Condutividade Hidráulica obtidos a partir dos Slug Tests.

\begin{tabular}{|c|c|c|}
\hline Poço de Monitoramento & Condutividade Hidráulica (cm/s) & Data \\
\hline PM-06 & $1,30 E-06$ & Fevereiro $/ 1999$ \\
\hline PM-13 & $3,12 E-05$ & Fevereiro $/ 2001$ \\
\hline PM-14 & $1,01 E-05$ & Fevereiro $/ 2001$ \\
\hline PM-18 & $5,30 E-05$ & Fevereiro $/ 2001$ \\
\hline
\end{tabular}

\subsubsection{Velocidade de fluxo da água subterrânea}

A partir destes resultados para condutividade hidráulica obtidos na área, da adoção de premissas (meio homogêneo, isotrópico e fluído incompressivel) e da utilização da Lei de Darcy para fluxo unidimensional, com porosidade efetiva para fluxo assumida como $18 \%$ (valor médio estimado a partir de Fetter, 1988 para litologias iguais à encontrada no local), a velocidade linear média para a água subterrânea no local foi calculada como variando entre 0,1 e 4,3 m/ano. 
A velocidade média da água subterrânea (v) foi obtida a partir da equação 01:

$$
v_{\mathrm{x}}=\frac{\mathrm{K}_{\mathrm{i}}}{\eta_{\mathrm{e}}} \quad \text { (equação 01) }
$$

Onde:

$v_{x}$ - velocidade linear média $[\mathrm{cm} / \mathrm{s}]$;

$K$ - condutividade hidráulica $[\mathrm{cm} / \mathrm{s}]$, obtido através de slug test;

i- gradiente hidráulico [-], obtido através dos mapas potenciométricos;

$\eta_{\theta}$ - porosidade efetiva [-], obtida através de Fetter, 1988.

A Tabela 05 apresenta um sumário dos valores obtidos para os parâmetros hidrogeológicos do local.

Tabela 05 - Sumário dos parâmetros hidrogeológicos.

\begin{tabular}{|c|c|c|c|c|}
\hline Parámetros Hidrogeológicos & PM - 06 & PM - 13 & PM - 14 & PM - 18 \\
\hline Gradiente Hidráulico (\%) & 0,04 & 0,04 & 0,046 & 0,046 \\
\hline Condutividade Hidráulica (cm/s) & $1,30 E-06$ & $3,12 E-05$ & $1,01 E-05$ & $5,32 E-05$ \\
\hline Porosidade Efetiva para Fluxo (\%) & 18 & 18 & 18 & 18 \\
\hline Velocidade Linear Média (m/ano) & 0,1 & 2,2 & 0,8 & 4,3 \\
\hline
\end{tabular}

É importante ressaltar que a determinação dos parâmetros do aqüifero fornece uma estimativa aproximada da migração dos potenciais contaminantes, uma vez que os cálculos baseados na Lei de Darcy consideram somente a advecção, não considerando a dispersão e o retardamento dos contaminantes mas, permitem uma projeção futura da extensão da pluma de contaminação através da utilização dos valores da velocidade de transporte de contaminantes pela água subterrânea. Estes valores permitirão um ótimo posicionamento de novos poços de monitoramento, bem como o tempo necessário para a realização de tarefas de remediação do local que se fizerem necessárias.

Entretanto, a velocidade linear média adotada nas estimativas de migração de contaminantes consideraram sempre a situação mais consenvadora, ou seja, a velocidade mais alta em cada trecho de interesse para o transporte do contaminante e o gradiente mais significativo para cada trecho, conforme tabela abaixo. 
Tabela 06 -Sumário dos parâmetros hidrogeológicos utilizados nas simulações de transporte.

\begin{tabular}{|c|c|c|c|}
\hline \multirow[b]{2}{*}{ Paramotros Hiarogeológicos } & \multicolumn{3}{|c|}{ Trecho de Transporte simulado } \\
\hline & $\begin{array}{l}\text { Fonte A ato } \\
\text { PM } 07\end{array}$ & $\begin{array}{l}\text { fonto A ato } \\
\text { rio cotla }\end{array}$ & $\begin{array}{c}\text { Fonte B até } \\
\text { nio Cotia }\end{array}$ \\
\hline Gradiente Hidrăulico (\%) & 0,046 & 0,043 & 0,040 \\
\hline Condutividade Hidráulica $(\mathrm{cm} / \mathrm{s})$ & $5,30 E-05$ & $4,31 E-05$ & $3,12 E-05$ \\
\hline Porosidade Efetiva para Fluxo (\%) & 18 & 18 & 18 \\
\hline Velocidade Linear Média (m/ano) & 4,3 & 3,2 & 2,2 \\
\hline
\end{tabular}

Cabe ressaltar que para o trecho entre a Fonte $A$ e o rio Cotia, adotaram-se médias ponderadas para as condutividades hidráulicas e gradientes, utilizados nos outros dois trechos menores que formam este maior, com distância de $135 \mathrm{~m}$ entre a Fonte A e o PM-07 e de 111 m entre a Fonte $B$ e o rio Cotia.

\subsection{Caracterização da Contaminação}

Para análise da situação de contaminação, foram avaliados os dados obtidos a partir das sondagens realizadas no local; de três eventos de amostragens de solo, das quatro etapas de instalação de poços de monitoramento e de nove eventos de monitoramento de água subterrânea, bem como a situação do rio Cotia, situado à jusante da empresa.

De acordo com os padrões ambientais utilizados pelos órgãos ambientais nacional e estadual, utilizaram-se parâmetros especificos para cada meio avaliado, águas superficiais, subterrâneas e solo. A apresentação dos resultados obtidos nestas avaliações estão a seguir.

\subsubsection{Caracterização da Contaminação do Solo}

Foram realizados três eventos de coletas e análises de solo, com amostras de solo (AS) de áreas externas à empresa para deteç̧ão de cloreto e metais e amostras de solo removido e depositado em caçambas, para determinação de 
parâmetros físico-químicos e cloreto, após processo de neutralização deste solo com calcário.

No primeiro evento, foram coletadas 21 amostras de solo, em profundidades de $1,0 \mathrm{~m}$, para determinação da existência de cloreto na zona não saturada. As amostras foram encaminhadas ao laboratório para realização de análises e determinação de parâmetros físico-químicos, sendo os resultados apresentados na tabela 07.

O solo local apresentava indícios de contaminação superficial nas proximidades da sondagem 01 (AS-01), caracterizados por coloração esbranquiçada identificada até profundidades médias de $0,05 \mathrm{~m}$.

Tabela 07 - Resultados dasAnálises de Solo para Cloreto, em junho de 1998.

\begin{tabular}{||c|c|c|c|c|}
\hline Amostra & $p H$ & $\begin{array}{c}\text { Condutividade } \\
\mu \mathrm{S}\end{array}$ & Cloreto (ppm) & Cloreto (mg/kg) \\
\hline AS-01 & 3,12 & 388 & 50 & 1000 \\
\hline$A S-02$ & 3,36 & 234 & 50 & 1000 \\
\hline$A S-03$ & 3,94 & 49,9 & 7 & 140 \\
\hline$A S-04$ & 4,07 & 41,3 & 5 & 100 \\
\hline$A S-05$ & 3,73 & 102 & 25 & 500 \\
\hline$A S-06$ & 3,88 & 64 & 10 & 200 \\
\hline$A S-07$ & 4,05 & 56,1 & 8 & 160 \\
\hline$A S-08$ & 3,83 & 85,9 & 18 & 360 \\
\hline$A S-09$ & 3,48 & 152 & 30 & 600 \\
\hline$A S-10$ & 4,51 & 38,3 & 7 & 140 \\
\hline$A S-11$ & 4,12 & 54,6 & 7 & 140 \\
\hline$A S-12$ & 3,63 & 135 & 30 & 600 \\
\hline$A S-13$ & 3,71 & 138 & 45 & 900 \\
\hline$A S-14$ & 2,99 & 442 & 5 & 100 \\
\hline$A S-15$ & 3,90 & 68,7 & 12 & 240 \\
\hline$A S-16$ & 4,75 & 53,7 & 18 & 360 \\
\hline$A S-17$ & 5,54 & 46,5 & 15 & 300 \\
\hline$A S-18$ & 4,35 & 66 & 20 & 400 \\
\hline$A S-19$ & 4,18 & 39,8 & 10 & 200 \\
\hline$A S-20$ & 4,49 & 78,9 & 20 & 400 \\
\hline$A S-21$ & 5,77 & 10 & $\leq 1$ & $\leq 20$ \\
\hline
\end{tabular}

Obs: Os resultados em ppm foram obtidos numa solução aquosa a $5 \%$ da amostra. Cloreto método turbidimétrico.

Os resultados de concentrações de cloreto em solo são fortemente influenciados pela superficie topográfica local e irregularidades ou interferências do 
terreno, como sarjetas, pavimentações, buracos e outras, uma vez que a migração do contaminante deu-se superficialmente com escoamento condicionado por estas caracteristicas e conseqüente infiltração no solo.

Nota-se associação direta entre os resultados de $\mathrm{pH}$ e condutividade, com os pontos de $\mathrm{pH}$ menor apresentando condutividades elétricas maiores, denotando a presença de íons no solo. A AS-21, à montante das demais, corrobora a distribuição das isolinhas ao apresentar $\mathrm{pH}$ mais elevado que os demais e concentrações de cloretos abaixo de 1,0 ppm.

Não existem parâmetros reguladores de qualidade ambiental para cloreto em nivel estadual ou nacional em solo. Matthess (1982) cita alguns tipos de rochas e suas concentrações em cloreto, variando entre 15 e $305 \mathrm{mg} / \mathrm{kg}$, evidenciando as altas concentrações no solo analisado. Entretanto, análises deste solo atualmente, apresentariam concentrações bastante menores, em função de lixiviação sofrida pelo cloreto no solo.

A localização das amostras de solo para análise de cloreto pode ser visualizada no mapa de localização (Figura 03).

As amostras do solo removido (ASR) da área afetada pelo vazamento de ácido clorídrico, foram coletadas em locais distintos e representativos dentro das caçambas nas quais encontrava-se armazenado este solo, após a neutralização feita através da aplicação de calcário e realizadas análises químicas, para verificação dos efeitos decorrentes deste processo de neutralização.

Como resultados das análises químicas do solo contaminado removido, foram obtidos os valores apresentados na Tabela 08 abaixo.

Tabela 08 - Resultados das Análises Químicas - Amostras de Solo Removido em Agosto de 1998.

\begin{tabular}{|c|c|c|c|c|}
\hline Amostra & $\mathbf{p H}$ & $\begin{array}{c}\text { Condutividado } \\
(\boldsymbol{\mu} \mathbf{S})\end{array}$ & $\begin{array}{c}\text { Cloreto } \\
(\mathbf{p p m})\end{array}$ & $\begin{array}{c}\text { Cloreto } \\
(\mathbf{m g} / \mathbf{k g})\end{array}$ \\
\hline ASR-01 & 9,15 & 2,19 & 800 & 16000 \\
\hline ASR-02 & 11,99 & 3,49 & 870 & 17400 \\
\hline ASR-03 & 9,79 & 2,08 & 800 & 16000 \\
\hline ASR-04 & 9,56 & 2,20 & 870 & 17400 \\
\hline ASR-05 & 11,61 & 3,22 & 510 & 10200 \\
\hline
\end{tabular}

Obs: Os resultados em ppm foram obtidos numa solução aquosa a 5\% da amostra. Cloreto método turbidimétrico 
Percebe-se pelos resultados das análises apresentados na Tabela 08 concentrações bastantes altas de cloreto presente no solo, evidenciando a presença do material oriundo do vazamento. Contudo, os principais efeitos negativos deste contaminante, diminuição do $\mathrm{pH}$ (pela presença de íons $\mathrm{H}^{+}$) e aumento da condutividade, foram eliminados pelos trabalhos de neutralização efetuados no local.

Os valores de $\mathrm{pH}$ encontrados mostram alcalinidade do solo analisado, evidenciando o resultado da neutralização pela adição de calcário. Os valores de condutividade não indicam anomalias ocasionadas pela presença de cloretos no local. Entretanto, este solo foi conduzido para uma área de descarte, providenciada pela Empresa.

Comparando-se aos resultados obtidos a partir das análises do solo coletado na área contaminada, em junho de 1998, o solo armazenado na caçamba possui maiores concentrações de cloretos com relação às amostras coletadas na área contaminada, uma vez que este solo removido foi o solo superficial mais atingido pelo vazamento.

As amostras coletadas na área contaminada apresentam valores de condutividade compreendidas no intervalo de 39,8 e $442 \mu \mathrm{S}$, enquanto as amostras coletadas da caçamba apresentaram valores dentro do intervalo de 2,08 e 3,49 $\mu \mathrm{S}$, indicando uma menor quantidade de ions dissolvidos resultantes da neutralização por calcário.

A amostra 21 foi desconsiderada por estar em local de controle, mas mesmo assim possui valor de condutividade superior e de $\mathrm{pH}$ inferior às encontradas na caçamba.

Assim, verificou-se que o processo de adição de calcário ao solo contaminado produziu efeitos positivos caracterizados pelo aumento dos valores de $\mathrm{pH}$ do solo e diminuição dos valores de condutividade, neutralizando os problemas originados pela presença de hidrogênio livre.

No terceiro evento, em fevereiro de 2001, foram coletadas cinco amostras de solo, sendo duas em área interna e três em área externa, para análise das concentrações dos metais cobre, chumbo e zinco. A tabela a seguir apresenta as profundidades de coleta $e$ as concentrações obtidas, em comparação com os Valores Orientadores do Sistema RAI (CETESB, 2001). 
Tabela 09 - Comparação dos valores de concentração em solo com os Valores Orientadores do Sistema RAI para Solo no Estado de São Paulo.

\begin{tabular}{|c|c|c|c|c|c|c|}
\hline Amostra & $\begin{array}{c}\text { Profundidade } \\
(m)\end{array}$ & $\begin{array}{c}\text { Parametro } \\
(\mathrm{mg} / \mathrm{kg})\end{array}$ & $\begin{array}{c}\text { Concentracáo } \\
\text { (mg/kg) }\end{array}$ & $\begin{array}{c}R \\
(m g / k g)\end{array}$ & $(\mathrm{A} / \mathrm{kg})$ & (mg/kg) \\
\hline \multirow{3}{*}{$A S-22$} & \multirow{3}{*}{0,80} & Cobre & 17 & 35 & 60 & 500 \\
\hline & & Chumbo & 103 & 17 & 100 & 350 \\
\hline & & Zinco & 176 & 60 & 300 & 1000 \\
\hline \multirow{3}{*}{$A S-23$} & \multirow{3}{*}{0,50} & Cobre & 129 & 35 & 60 & 500 \\
\hline & & Chumbo & 409 & 17 & 100 & 350 \\
\hline & & Zinco & 705 & 60 & 300 & 1000 \\
\hline \multirow{3}{*}{$A S-24$} & \multirow{3}{*}{0,50} & Cobre & 7,6 & 35 & 60 & 500 \\
\hline & & Chumbo & 48 & 17 & 100 & 350 \\
\hline & & Zinco & 29,8 & 60 & 300 & 1000 \\
\hline \multirow{3}{*}{$A S-25$} & \multirow{3}{*}{0,50} & Cobre & 20 & 35 & 60 & 500 \\
\hline & & Chumbo & 92 & 17 & 100 & 350 \\
\hline & & Zinco & 83,5 & 60 & 300 & 1000 \\
\hline \multirow{3}{*}{$A S-26$} & \multirow{3}{*}{0,50} & Cobre & 12 & 35 & 60 & 500 \\
\hline & & Chumbo & 51 & 17 & 100 & 350 \\
\hline & & Zinco & 44,9 & 60 & 300 & 1000 \\
\hline
\end{tabular}

Para o cobre observa-se que somente a amostra de solo AS-23 apresentou concentração acima do valor de alerta $(A)$ estabelecido, porém muito abaixo do valor de intervenção (l).

Em relação ao chumbo, pode-se observar que os resultados obtidos nas amostras ASs 24, 25 e 26 estão acima do valor de referência de qualidade $(R)$ e abaixo do valor de alerta (A). A amostra AS-22 apresentou concentração pouco acima do valor de alerta (A), implicando na necessidade de monitoramento do elemento em solo no local. Entretanto, a concentração obtida na amostra AS-23 está acima do VI estabelecido, indicando a necessidade de avaliação de risco para o metal em solo.

O chumbo é classificado pela USEPA como pertencente ao Grupo B2 (provavelmente carcinogênico, com suficientes evidências em estudos em animais e evidências inadequadas ou ausência de dados de estudos epidemiológicos).

Para o elemento zinco, observa-se que somente a amostra AS - 23 apresentou concentração acima do valor de alerta (A), e inferior ao valor de intervenção (I) regulamentado, indicando que somente medidas de monitoramento devem ser tomadas em relação ao elemento em solo. 
Não foi realizada avaliação de risco em solo dentro da área da empresa devido aos resultados baixos obtidos, corroborado pelo fato da remoção de solo do local.

\subsubsection{Caracterização da Contaminação da Água Subterrânea}

Realizaram-se nove eventos de monitoramento da qualidade da água subterrânea, a partir dos quais amostras foram coletadas para análises físicoquímicas, variando entre um total de 3 a 11 poços de monitoramento ativos, conforme data do evento e, no primeiro evento, através de duas sondagens que atingiram a água para coleta e análise.

De acordo a Portaria 1469 - Ministério da Saúde de 29/12/2000 e Sistema RAl de Valores Orientadores no Estado de São Paulo - CETESB, 2001, são estipulados valores máximos permitidos (VMP) e valores de intervenção (l) aos parâmetros avaliados, respectivamente, de acordo com a tabela 10 a seguir.

Tabela 10 - Padrões de Potabilidade estabelecidos pelos órgãos ambientais.

\begin{tabular}{|c|c|c|c|}
\hline \multirow[b]{2}{*}{ Parâmetro } & \multirow[b]{2}{*}{ Unidade } & \multicolumn{2}{|c|}{ Padröes de Potabilidade } \\
\hline & & $\begin{array}{l}\text { Portaria } 1469- \\
\text { Ministério da } \\
\text { Saúde }\end{array}$ & $\begin{array}{c}\text { CETESB - Valores } \\
\text { de Intervenção }\end{array}$ \\
\hline Temperatura & $(C)$ & - & - \\
\hline$p H$ & - & $6,0-9,5$ & - \\
\hline$E h$ & $(m V)$ & - & - \\
\hline Condutividade & $\left(\mu \mathrm{Scm}^{-1}\right)$ a $\left.25{ }^{\circ} \mathrm{C}\right)$ & - & - \\
\hline Cloreto & $m g / L$ & 250 & - \\
\hline Cobre & $m g / L$ & 2,0 & 1,0 \\
\hline Chumbo & $m g / L$ & 0,01 & 0,05 \\
\hline Zinco & $m g / L$ & 5,0 & 5,0 \\
\hline
\end{tabular}

O critério estabelecido pelo Sistema RAl para adoção de valores de intervenção foi o de adotar os padrões de potabilidade da Portaria 36, de 1990. Entretanto, após a homologação da Portaria 1469, que veio a substituir a 36, alguns valores tornaram-se discrepantes, visto que em alguns casos a nova Portaria abaixou os limites e em outros, os aumentou. Para este trabalho, foram considerados os limites propostos pela Portaria 1469. 
Em relação ao chumbo, embora o limite proposto pela CETESB seja superior ao da Portaria 1469, o próprio documento de valores orientadores da CETESB (2000) cita estudos que sugerem uma redução do limite para 0,02 mg/L.

Pode-se obsenvar que, dos parâmetros físicos avaliados, apenas o $\mathrm{pH}$ pode influir no padrão de potabilidade da água.

\subsubsection{1 pH, Eh e Condutividade Elétrica}

Os resultados de $\mathrm{pH}$ em solo observados no capítulo anterior, predominantemente entre 3 e 4, caracterizando um meio ácido, influenciaram diretamente na mobilidade dos metais da zona não saturada para a zona saturada, visto que, a mobilidade de cátions metálicos é maior sob condições ácidas.

O solo constitui importante barreira de proteção das águas subterrâneas contra a contaminação proveniente de metais, exercendo controle sobre a mobilidade dos metais em solução através de mecanismos como adsorção, troca catiônica, precipitação e co-precipitação, complexação orgânica, entre outros. A participação destes mecanismos no processo de retenção, bem como o comportamento geral dos ions em solução no solo, devem-se às condições físicoquímicas do solo e das concentrações de cada íon disponível em solução no solo.

As altas concentrações de chumbo e zinco detectadas em água subterrânea na área, indicam a grande mobilidade destes ions para a água, dificultando a avaliação destes mecanismos de retenção em solo. Isto deve ter ocorrido em função do decréscimo do $\mathrm{pH}$ devido ao vazamento de ácido clorídrico ter solubilizado e mobilizado os metais anteriormente presentes no solo.

Os resultados de $\mathrm{pH}$ em água subterrânea apresentaram valores baixos (entre 3 e 4) para a maioria dos poços, indicando ambiente de mobilidade para metais em água subterrânea.

Assim, em função da complexidade do estudo do comportamento dos íons metálicos devido à heterogeneidade do solo e variabilidade de propriedades físicas, químicas e mineralógicas deste, optou-se pela desconsideração de qualquer parâmetro de retardamento no transporte de metais.

Resultados de $\mathrm{pH}$ e Eh obtidos em eventos que também contemplaram as análises de metais, foram utilizados para plotagem em diagramas pH-Eh para 
caracterização dos campos de estabilidade destes metais na água subterrânea do local. Estes diagramas encontram-se no item de resultados dos respectivos metais.

Tabela 11 - Resultados de pH em Água Subterrânea

\begin{tabular}{|c|c|c|c|c|c|c|c|c|c|}
\hline \multirow{3}{*}{ Poço } & \multicolumn{9}{|c|}{ Parámetro-pH } \\
\hline & \multicolumn{9}{|c|}{ Data de Evento de Monitoramento } \\
\hline & $\begin{array}{l}\text { Fov } \\
1998\end{array}$ & $\begin{array}{c}\text { Jun } \\
1998\end{array}$ & $\begin{array}{l}\text { Dez } \\
1998\end{array}$ & $\begin{array}{l}\text { Fev } \\
1999\end{array}$ & $\begin{array}{l}\text { Maio } \\
1999\end{array}$ & $\begin{array}{l}\mathrm{Jan} \\
2000\end{array}$ & $\begin{array}{l}A b r i l \\
2000\end{array}$ & $\begin{array}{l}\text { Jun } \\
2000\end{array}$ & $\begin{array}{l}\mathrm{FeV} \\
2001\end{array}$ \\
\hline$S D-01$ & 3,36 & - & - & - & - & - & - & - & - \\
\hline$S D-02$ & 3,26 & - & - & - & - & - & - & - & - \\
\hline$P M-01$ & ${ }^{* * *}$ & 3,28 & 0,55 & 3,14 & 3,43 & 3,81 & $\star *$ & ** & ** \\
\hline$P M-02$ & 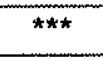 & 5,58 & 2,39 & 2,94 & 3,19 & 2,97 & ** & $\star *$ & $\star \star$ \\
\hline$P M-03$ & 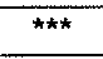 & 3,96 & 2,98 & 2,90 & 3,26 & ** & ** & ** & ** \\
\hline$P M-04$ & *** & 4,15 & 3,03 & 3,42 & 3,24 & $*$ & * & * & * \\
\hline$P M-05$ & $\star \star \star \star$ & 3,65 & 3,07 & 3,53 & 3,48 & $*$ & ${ }^{*}$ & $*$ & * \\
\hline$P M-06$ & $* * *$ & 5,93 & 7,33 & 5,93 & 5,96 & 5,84 & 6,02 & 6,18 & 5,81 \\
\hline$P M-07$ & $\star \star \star k$ & **** & $* * *$ & 3,54 & 3,49 & 3,50 & 3,21 & 3,19 & 3,77 \\
\hline$P M-08$ & $\hbar \star \star \star x$ & *** & *** & 6,37 & 6,85 & 6,47 & 6,47 & $\star \star \star$ & 6,28 \\
\hline$P M-09$ & $* * *$ & $* * \star$ & $* * \star *$ & 4,40 & ${ }^{*}$ & ${ }^{*}$ & $*$ & * & * \\
\hline$P M-10$ & 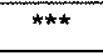 & 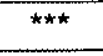 & 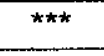 & $* * \star$ & 6,28 & ** & ${ }^{* *}$ & $* *$ & ** \\
\hline$P M-11$ & $* * *$ & 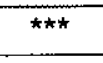 & 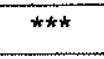 & $* * * *$ & 3,60 & 3,27 & 3,11 & 3,08 & 3,20 \\
\hline$P M-12$ & $\star * * *$ & **** & 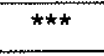 & $* k \hbar$ & 3,77 & $* *$ & ** & $\star \star$ & ${ }^{\star \star \star}$ \\
\hline$P M-13$ & 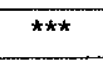 & $* * *$ & $\star \star \star \star *$ & $\star \star \star \star$ & $\star * * *$ & $* * *$ & $\star \star \star \star$ & $* * *$ & 3,20 \\
\hline$P M-14$ & $\star * \star \star$ & $* * * *$ & $\star \star \star \star ~$ & $* * *$ & $* * *$ & $* * *$ & $* * *$ & $\star * * *$ & 3,31 \\
\hline$P M-15$ & $* * *$ & **** & **** & 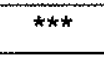 & $\star \star \star \star *$ & 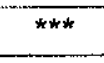 & **** & $* * *$ & 3,32 \\
\hline$P M-16$ & $* * *$ & $\star \star \star \star$ & 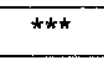 & $* * *$ & $\star \star \star *$ & $\star \star \star *$ & $\star \star \star \star$ & $* * *$ & 3,87 \\
\hline$P M-17$ & 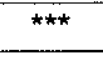 & $* * *$ & $\star * * *$ & $* * *$ & $\star \star \star * *$ & $\star \star \star \star$ & $\star \star \star *$ & $* * *$ & 3,22 \\
\hline$P M-18$ & $\star \star \star *$ & $\star \star \star * *$ & $* \star \star *$ & *** & **** & $\star \star \star *$ & $* * *$ & $* * *$ & 3,41 \\
\hline$P M-19$ & $\star \star \star *$ & $\star \star \star *$ & $\star * * *$ & $\star \star \star$ & $* \star \star \star$ & 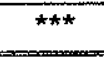 & $* * *$ & $* \star *$ & 6,38 \\
\hline
\end{tabular}

"Poço danificado; ** Poço seco; *** Poço ainda não instalado

Ao considerar-se o intenvalo de pH estabelecido pela Portaria 1469, observase que o PM-08 em todas as medidas, os PMs 10 e 19 em suas únicas medidas e o PM-06 em algumas, apresentaram resultados dentro da faixa estabelecida, enquanto todos os outros poços apresentaram valores abaixo do limite estipulado pela Portaria. Estes resultados estão diretamente associados ao vazamento de ácido cloridrico na área, visto que locais não atingidos mostram pH mais elevado. Ressalta-se que estes poços citados apresentaram as menores concentrações de cloreto e metais.

Na comparação entre os resultados obtidos ao longo das avaliações, para cada poço com mais de uma medida e mesmo poços próximos ou em substituição a 
poços inativos, notam-se valores muito próximos, com pequenas oscilações. Entretanto, cabe destacar as medidas de pH para os PMs 01 e 02 em dezembro de 1998, que apresentaram valores muito baixos, principalmente o primeiro $(p H=0,55)$. O cruzamento destes dados com os resultados de condutividade elétrica $\theta$ concentração de cloreto para estes poços, permite perceber uma correlação direta, com as maiores condutividades e concentrações de cloreto associadas aos menores pHs.

Uma pluma de isovalores de pH em água subterrânea, considerando-se os resultados do último evento de monitoramento, está apresentada na figura 06.

Tabela 12 - Resultados de Eh em Água Subterrânea

\begin{tabular}{|c|c|c|c|c|}
\hline \multirow{3}{*}{$\begin{array}{c}\text { Poço de } \\
\text { Monitoramento }\end{array}$} & \multicolumn{4}{|c|}{ Parámetro - Eh $(m \mathrm{~V})$} \\
\hline & \multicolumn{4}{|c|}{ Data de Evento de Monitoramento } \\
\hline & Janeiro 2000 & Abril 2000 & Junho 2000 & Feverolro 2001 \\
\hline$P M-01$ & 384 & $* *$ & $* *$ & $* *$ \\
\hline$P M-02$ & 428 & $\star * *$ & $\star \star$ & ** \\
\hline$P M-03$ & ** & $\star \star$ & ** & ** \\
\hline$P M-04$ & $\star$ & * & $*$ & * \\
\hline$P M-05$ & * & * & * & * \\
\hline$P M-06$ & -17 & 180 & 167 & 286 \\
\hline$P M-07$ & 490 & 555 & 576 & 502 \\
\hline$P M-08$ & -85 & 85 & $\star \star *$ & 165 \\
\hline$P M-09$ & * & * & * & * \\
\hline$P M-10$ & $\star \star$ & $\star \star$ & ** & $\star *$ \\
\hline$P M-11$ & 420 & 548 & 541 & 571 \\
\hline$P M-12$ & $\star \star$ & $\star *$ & ** & $* *$ \\
\hline$P M-13$ & $k * *$ & $* \star * *$ & $* * *$ & 579 \\
\hline$P M-14$ & k*k & $* * *$ & $\star \star \star \star$ & 579 \\
\hline$P M-15$ & $\star * * *$ & $* * *$ & *** & 365 \\
\hline$P M-16$ & $\star \star \star \star$ & $* * *$ & $\star \star \star \star$ & 487 \\
\hline$P M-17$ & $* * *$ & $\star \star \star *$ & $\star \star \star \star$ & 594 \\
\hline$P M-18$ & $* * *$ & $\star * * *$ & $* * *$ & 548 \\
\hline$P M-19$ & $* * *$ & $\hbar \star \star *$ & $\star \star \star \star *$ & 336 \\
\hline
\end{tabular}

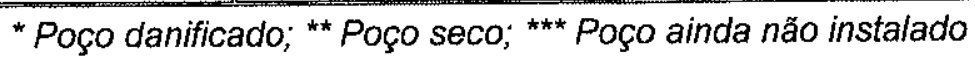

Apesar de não haver limites estabelecidos para as concentrações de Eh (potencial de oxi-redução), notam-se os valores mais baixos para os PMs 06, 08, 15 e 19, em relação direta com os resultados de $\mathrm{pH}$ nos mesmos poços, visto que o PM-15 é um poço de montante muito próximo do PM-10. Estes valores são caracterizados pelas baixas concentrações de oxigênio dissolvido nas águas subterrâneas. 


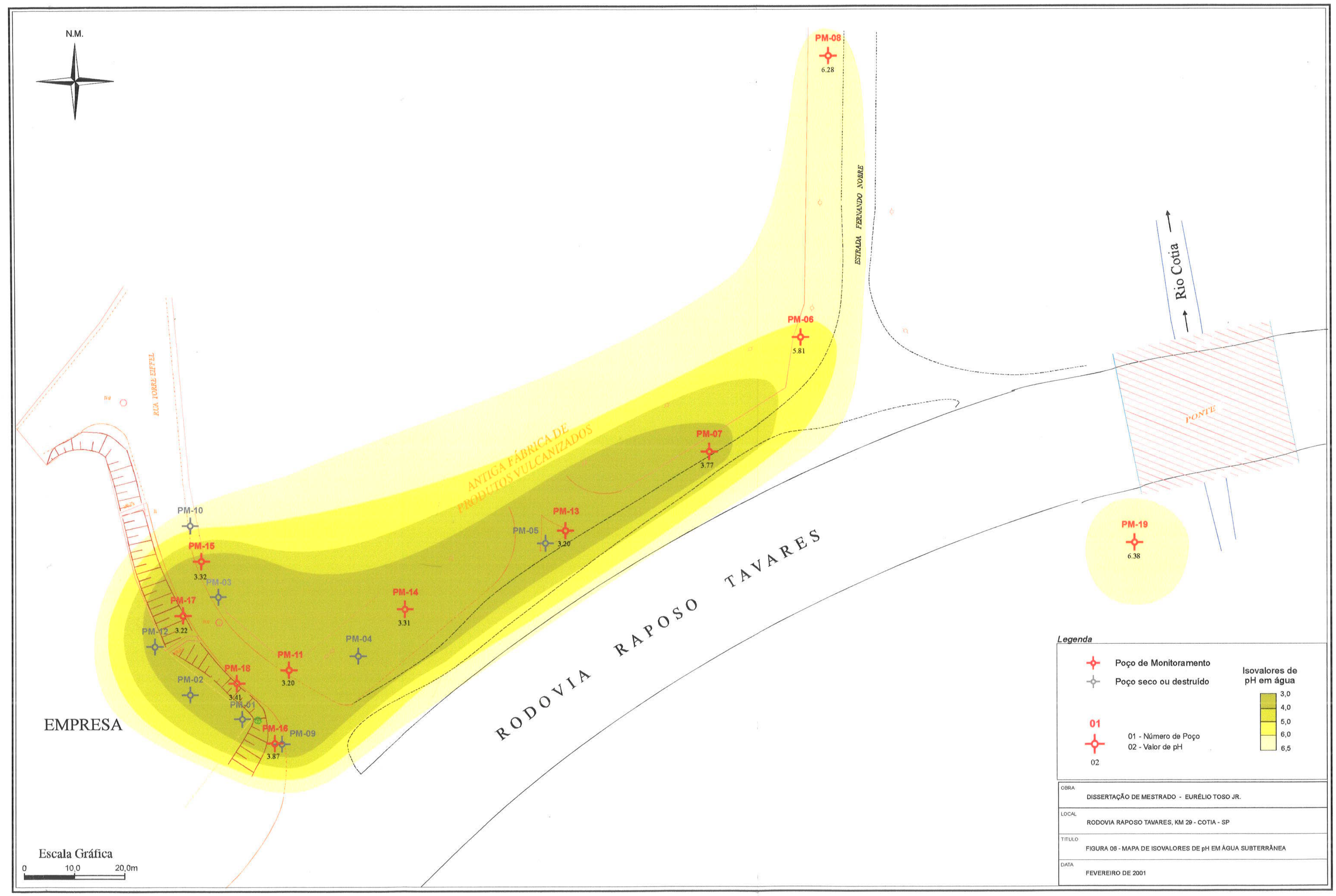


Tabela 13 - Resultados de Condutividade Elétrica em Água Subterrânea

\begin{tabular}{|c|c|c|c|c|c|c|c|c|c|}
\hline \multirow{3}{*}{ Poco } & \multicolumn{9}{|c|}{ Parametro - Condutividade $\left(\mathrm{mscm}^{-1}\right)$} \\
\hline & \multicolumn{9}{|c|}{ Data de Evento de Monitoramento } \\
\hline & $\begin{array}{l}\text { fov } \\
1998\end{array}$ & $\begin{array}{l}J u / \\
1998\end{array}$ & $\begin{array}{l}\text { Dez } \\
1998\end{array}$ & $\begin{array}{l}\text { fev } \\
1999\end{array}$ & $\begin{array}{l}\text { Maio } \\
1999\end{array}$ & $\begin{array}{l}\text { Jan } \\
2000\end{array}$ & $\begin{array}{l}\text { Abril } \\
2000\end{array}$ & $\begin{array}{l}J u n h o \\
2000\end{array}$ & $\begin{array}{l}\mathrm{Fov} \\
2001\end{array}$ \\
\hline$S D-01$ & 7,59 & - & - & - & - & - & - & - & - \\
\hline$S D-02$ & 6,62 & - & - & - & - & - & - & - & - \\
\hline$P M-01$ & $* * *$ & 5,11 & 42,75 & 2,82 & 2,73 & 2,35 & ** & 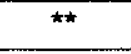 & $\star *$ \\
\hline$P M-02$ & $* k *$ & 1,62 & 14,25 & 1,31 & 1,26 & 8,01 & $* *$ & $\star *$ & ** \\
\hline$P M-03$ & $\star \star \star *$ & 0,92 & 3,31 & 0,72 & 0,47 & $\hbar *$ & ** & ** & ** \\
\hline$P M-04$ & $* \star * *$ & 4,33 & 5,65 & 2,61 & 3,96 & $\star$ & * & * & * \\
\hline$P M-05$ & $\star \star \star \star$ & 5,41 & 6,92 & 0,86 & 4,42 & * & * & * & * \\
\hline$P M-06$ & $\star \star \star \star$ & 0,58 & 0,83 & 0,52 & 0,43 & 0,57 & 0,56 & 0,56 & 0,39 \\
\hline$P M-07$ & $* \star *$ & $* * \star *$ & $\star \star \star \star *$ & 4,27 & 3,39 & 4,80 & 4,93 & 4,69 & 4,98 \\
\hline$P M-08$ & $* \star * *$ & $* \star \star$ & $* * *$ & 0,33 & 0,37 & 0,30 & 0,37 & ** & 0,32 \\
\hline$P M-09$ & $\star \star \star *$ & $\star \star \star \star$ & $* \star \star \star$ & 1,41 & $*$ & $*$ & * & * & * \\
\hline$P M-10$ & $\star \star \star \star$ & $\star * * *$ & $* \star *$ & $\star \star \star$ & 0,45 & $\star * *$ & $* *$ & $k *$ & $\star * *$ \\
\hline$P M-11$ & $* * *$ & $* * * *$ & $* \star \star$ & $k \star \star$ & 2,21 & 4,58 & 3,61 & 4,20 & 3,53 \\
\hline$P M-12$ & $\star \star \star$ & $k * *$ & *** & $\star \star \star *$ & 3,61 & $\star *$ & ** & $\star \star *$ & ** \\
\hline$P M-13$ & $\star \star \star \star$ & $\star \star \star \star$ & *** & *** & $\star \star \star *$ & $* * *$ & k** & *** & 4,47 \\
\hline$P M-14$ & $\star \star \star *$ & $\hbar \star \star$ & $\star \star \star \star$ & $\star \star \star \star$ & $* \star *$ & $* * *$ & $\star \star \star \star$ & $* * *$ & 1,47 \\
\hline$P M-15$ & $\star \star * *$ & $\star * *$ & $* * *$ & $\star \star \star \star *$ & $\star \star \star \star$ & 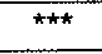 & $* * *$ & $\hbar * \star$ & 1,18 \\
\hline$P M-16$ & $* * *$ & $* * *$ & $* * *$ & $\star * *$ & $\hbar \star \star \star$ & $* * *$ & $* * *$ & $\star * *$ & 2,42 \\
\hline$P M-17$ & $\star \star \star \star$ & $* * *$ & $\star \star \star *$ & 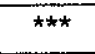 & $* * *$ & $\hbar * \star$ & $* * *$ & $\star \star \star \star$ & 3,96 \\
\hline$P M-18$ & $\pi \star \star$ & $* * *$ & $\star \star *$ & $\star \star \star \star$ & $* * *$ & $\star * *$ & $* * *$ & $* * *$ & 7,24 \\
\hline$P M-19$ & $\star \star \star \star$ & 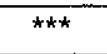 & $* * \star$ & $\star \star \star *$ & $* * *$ & $* \star \star \star$ & $\star \star \star \star$ & $* * *$ & 0,41 \\
\hline
\end{tabular}

*Poço danificado; ** Poço seco; *** Poço ainda não instalado

As menores condutividades elétricas foram medidas nos PMs 06, 08, 10, 15 e 19 , confirmando a correlação de condutividades menores para $\mathrm{pH}$ maiores. As maiores condutividades elétricas determinadas para as amostras de água coletadas no local foram obtidas nas SDs 01 e 02 e nos PMs 01, 02, 04, 05, 07 e 18, em momentos cujas análises químicas detectaram a grande presença de ions dissociados na água subterrânea (cloreto e metais, conforme evento), corroborando as associações com os resultados citados acima. 


\subsubsection{Cloreto}

Para a detecção de cloreto em água subterrânea foram realizados cinco eventos de monitoramento, sendo o primeiro a partir das SDs 01 e 02 e os restantes com coleta nos poços instalados e ativos na data. $O$ último evento de monitoramento para cloreto data de maio de 1999. Os resultados obtidos nas análises químicas estão apresentados na tabela a seguir.

Tabela 14 - Resultados de Cloreto em Água Subterrânea

\begin{tabular}{|c|c|c|c|c|c|}
\hline \multirow{3}{*}{$\begin{array}{l}\text { Poço de } \\
\text { Monitoramento }\end{array}$} & \multicolumn{5}{|c|}{ Parâmetro - Cloreto $(\mathrm{Mg} / \mathrm{L})$} \\
\hline & \multicolumn{5}{|c|}{ Data de Evento de Monitoramento } \\
\hline & Fevereiro 98 & Julho 98 & Dezembro 98 & Fevereiro 99 & Malo 99 \\
\hline$S D-01$ & 2570 & - & - & - & - \\
\hline$S D-02$ & 2170 & - & - & - & - \\
\hline$P M-01$ & $\star * *$ & 2325 & 7010 & 1300 & 985 \\
\hline$P M-02$ & 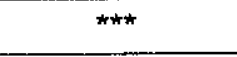 & 435 & 5330 & 480 & 425 \\
\hline$P M-03$ & $k \star \star$ & 290 & 965 & 218 & 90 \\
\hline$P M-04$ & *k* & 1745 & 1900 & 930 & 1455 \\
\hline$P M-05$ & *** & 2250 & 2345 & 50 & 2235 \\
\hline$P M-06$ & $\star \star \star * *$ & 100 & 140 & 180 & 88 \\
\hline$P M-07$ & $* * *$ & $* * *$ & $\star * \star \star$ & 1300 & 1240 \\
\hline$P M-08$ & $\star * \star$ & $* \star *$ & $\star * *$ & 5 & 14 \\
\hline$P M-09$ & $\star \star *$ & $\star * *$ & $\star \star \star \star$ & 455 & * \\
\hline$P M-10$ & $* * k$ & $\star \star \star$ & $\star \star \star \star *$ & $* * *$ & 106 \\
\hline$P M-11$ & $* * *$ & $\star \star \star$ & $k * \star$ & $* * *$ & 835 \\
\hline$P M-12$ & $\star \star *$ & $* \star \star *$ & $* * *$ & $\star * *$ & 815 \\
\hline
\end{tabular}

"Poço danificado; "* Poço seco; *** Poço ainda não instalado

As máximas concentrações de cloreto em água subterrânea foram detectadas em dezembro de 1998 nos PMs-01 e 02, 28 e 21,3 vezes acima do padrão de potabilidade regulamentado, respectivamente. Entretanto, nos dois eventos posteriores (e últimos) as concentrações decresceram acentuadamente, indicando migração da pluma e diluição no aqüifero.

Na pluma de contaminação configurada a partir do último evento (maio de 99), a maior concentração foi detectada no PM-05. Os poços 03, 06, 08 e 10 apresentaram concentrações abaixo do limite estabelecido, o que limita a pluma de 
contaminação mais próxima à Rodovia Raposo Tavares e proximidades da Empresa, até a data.

Com relação aos parâmetros físicos avaliados, percebe-se a direta correlação com os dados obtidos, havendo aumento proporcional nos valores de condutividade e na concentração de cloretos com simultâneo decaimento do $\mathrm{pH}$.

A configuração da pluma de cloreto, baseada no último evento conforme figura 07, não é uma pluma indicativa da migração do contaminante somente em função do fluxo subterrâneo, visto que ao ocorrer o vazamento houve principalmente um extenso escoamento superficial do produto, que chegou a atingir áreas externas da empresa e conseqüente infiltração nas zonas não saturada e saturada.

Entretanto, análises das amostras de água coletadas dos PMs instalados nas proximidades da Empresa, indicaram deslocamento da pluma de contaminação com aumento das concentrações de cloretos e conseqüente aumento de condutividade e diminuição de $p H$, principalmente nos poços situados mais próximos da Empresa e conseqüentemente da área fonte de contaminação (PMs 01 e 02).

A observação dos resultados de pH e Eh, medidos nos eventos de monitoramento, mostra resultados com pouca oscilação ao longo do tempo nos respectivos poços. Assim, apesar de não haver resultados de análises de cloreto no período entre janeiro de 2000 e fevereiro de 2001, quando foram realizadas medidas de Eh, a plotagem dos dados de $\mathrm{pH}$ e Eh no diagrama $\mathrm{Cl}-\mathrm{O}-\mathrm{H}$ mostra ambiente compativel ao campo de estabilidade do ion $\mathrm{Cl}^{-}$em água.

A figura 08 apresenta os diagramas $\mathrm{pH}$-Eh para o sistema Cl-O-H (modificado de Brookins, 1988), referentes aos quatro eventos de monitoramento que dispõem destes dados. O número de pontos plotados em cada diagrama refere-se ao número de poços ativos em cada evento.

O diagrama mostra um amplo campo de $\mathrm{Cl}^{\text {; }}$, ocupando quase toda a área do diagrama. $\mathrm{O} \mathrm{Cl}$ oxida para $\mathrm{ClO}_{3}{ }^{-}$em condições de altos valores de Eh. Pode-se observar nos diagramas com os dados plotados que todo os pontos encontram-se no campo do $\mathrm{Cl}^{-}$. Estes resultados mostram que as condições de $\mathrm{pH}$ e Eh na água subterrânea do local indicam estabilidade para o ion cloreto em água subterrânea. 


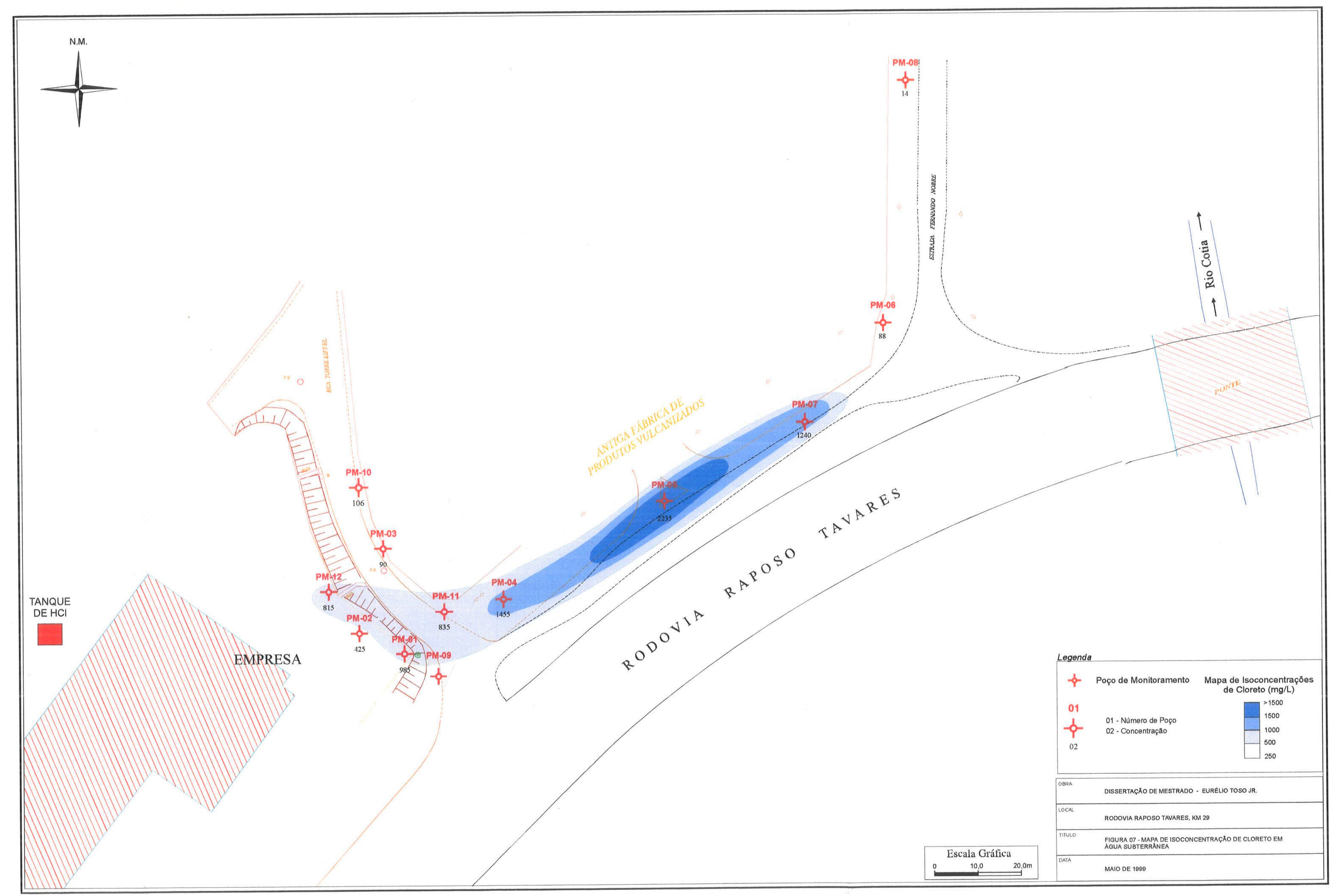



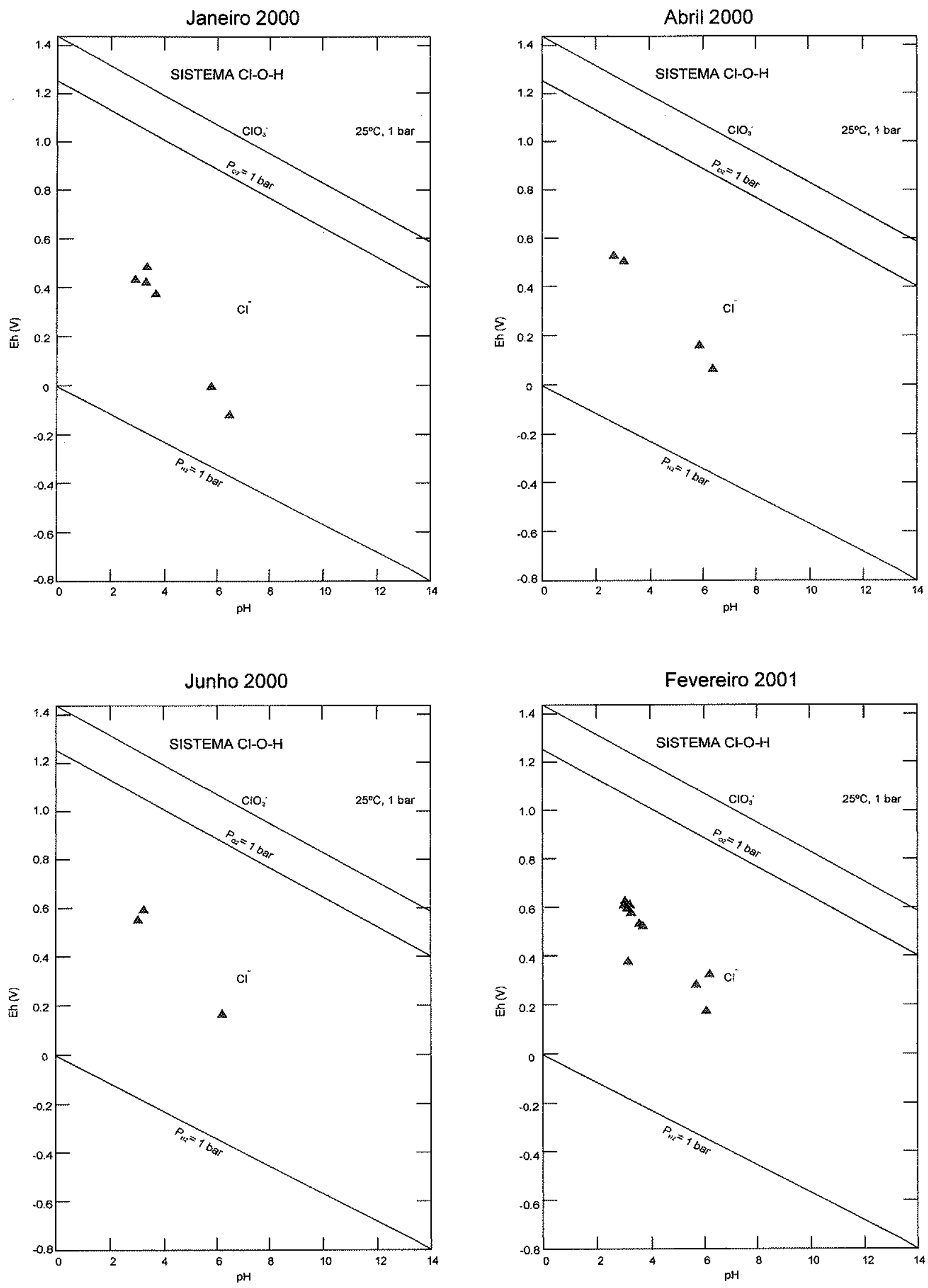

Figura 08 - Diagramas pH-Eh para o sistema Cl-O-H (Modificado de Brookins, 1988). Os dados plotados referem-se aos poços ativos em cada evento de monitoramento representado. 


\subsubsection{Metais - Cobre, Chumbo e Zinco}

Quanto às análises de metais, devem-se interpretar os resultados para cada metal separadamente, em função da distinção dos valores obtidos para cada metal e do grau de toxicidade de cada um.

O monitoramento para metais foi realizado pela primeira vez em janeiro de 2000, estendendo-se por mais três eventos até fevereiro de 2001. Em função de problemas de poços inativos (danificados ou secos), os resultados de metais são insuficientes para configuração de pluma(s) nos três primeiros eventos, configurando-se plumas somente para o último evento.

Os limites de deteç̧ão para os metais chumbo, cobre e zinco, nos equipamentos e métodos utilizados nas análises são, respectivamente, 0,05, 0,01 e $0,001 \mathrm{mg} / \mathrm{L}$. Assim, cabe ressaltar que o limite de detecção para o chumbo, está acima do novo padrão regulamentado pela Portaria $1469 \mathrm{em}$ dezembro de 2000 , visto que o limite anterior de $0,05 \mathrm{mg} / \mathrm{L}$ era atendido pelo método.

Os resultados obtidos para cada metal estão apresentados nas tabelas 15, 16 e 17, junto com as discussões referentes aos resultados apresentados nestas tabelas.

\section{Cobre}

Para o Cobre, todos os resultados obtidos estão abaixo dos limites estabelecidos, não havendo qualquer recomendação de medida futura em relação ao elemento. De qualquer modo, destaca-se que a maior concentração obtida foi no PM-18, podendo-se associar o resultado à empresa, porém sem comprometimento da qualidade da água subterrânea em relação a este elemento.

O comportamento do cobre na água subterrânea pode ser avaliado pelas condições de $\mathrm{Eh}$ e $\mathrm{pH}$ atuantes. A figura 09 apresenta os diagramas $\mathrm{pH}$-Eh para $\mathrm{O}$ sistema Cu-O-H (Brookins, 1988), referentes aos quatro eventos de monitoramento que dispõem destes dados. O número de pontos plotados em cada diagrama referese ao número de poços ativos em cada evento. 
Tabela 15 - Resultados de Cobre em Água Subterrânea.

\begin{tabular}{|c|c|c|c|c|}
\hline \multirow{3}{*}{$\begin{array}{l}\text { Poco de } \\
\text { Monitoramento }\end{array}$} & \multicolumn{4}{|c|}{ Parametro - oobre $(\mathrm{g} g / \mathrm{L})$} \\
\hline & \multicolumn{4}{|c|}{ Data do Evento do Monitoramento } \\
\hline & Janeiro 2000 & $A b r I 2000$ & Junho 2000 & Feverelro 2001 \\
\hline$P M-01$ & 0,20 & 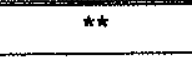 & ** & $* \star$ \\
\hline$P M-02$ & 0,30 & ** & ** & ** \\
\hline$P M-03$ & $* *$ & ** & ** & ** \\
\hline$P M-04$ & * & * & $\star$ & * \\
\hline$P M-05$ & * & * & * & * \\
\hline$P M-06$ & $<0,05$ & $<0,05$ & $<0,05$ & 0,060 \\
\hline$P M-07$ & 0,11 & 0,10 & 0,12 & 0,205 \\
\hline$P M-08$ & $<0,05$ & $<0,05$ & $* *$ & 0,016 \\
\hline$P M-09$ & * & $*$ & * & * \\
\hline$P M-10$ & $\star \star$ & $* *$ & $* *$ & ** \\
\hline$P M-11$ & 0,34 & 0,29 & 0,34 & 0,289 \\
\hline$P M-12$ & $\star \star$ & $\star * *$ & $\star *$ & $* *$ \\
\hline$P M-13$ & $* * *$ & $* * *$ & $\hbar \star \star$ & 0,532 \\
\hline$P M-14$ & $* * \star$ & $* * *$ & $\star \star \star *$ & 0,205 \\
\hline$P M-15$ & $\star \star \star \star$ & 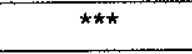 & $\star \star * \star$ & 0,042 \\
\hline$P M-16$ & *k* & $\star \star \star \star *$ & $* * *$ & 0,276 \\
\hline$P M-17$ & $k \star *$ & $* * *$ & $\star \star * \star$ & 0,430 \\
\hline$P M-18$ & $\star \star \star \star$ & $* * *$ & $* * *$ & 0,744 \\
\hline$P M-19$ & $\star \star \star \star$ & $* \star *$ & $* * \star$ & 0,095 \\
\hline
\end{tabular}

* Poço danificado; ** Poço seco; *** Poço ainda não instalado

O diagrama mostra um amplo campo de $\mathrm{Cu}$ nativo em condições redutoras. $\mathrm{O}$ $\mathrm{Cu}$ nativo oxida para $\mathrm{Cu}^{2+}$ em ambiente ácido e para $\mathrm{Cu}_{2} \mathrm{O}$ em condições básicas. $\mathrm{Cu}_{2} \mathrm{O}$ oxida para $\mathrm{CuO}$ sob condições de maior Eh. Em ambientes de $\mathrm{pH}$ muito altos, o CuO dissolve para $\mathrm{CuO}_{2}{ }^{2-}$. Pode-se observar nos diagramas com os dados plotados que a maioria dos pontos encontram-se no campo do $\mathrm{Cu}^{2+}$ e apenas um ponto no campo do $\mathrm{Cu}_{2} \mathrm{O}$. Estes resultados mostram que as condições de $\mathrm{pH}$ e Eh na água subterrânea do local, o cobre se mantém estável na forma $\mathrm{Cu}^{2+}$. 

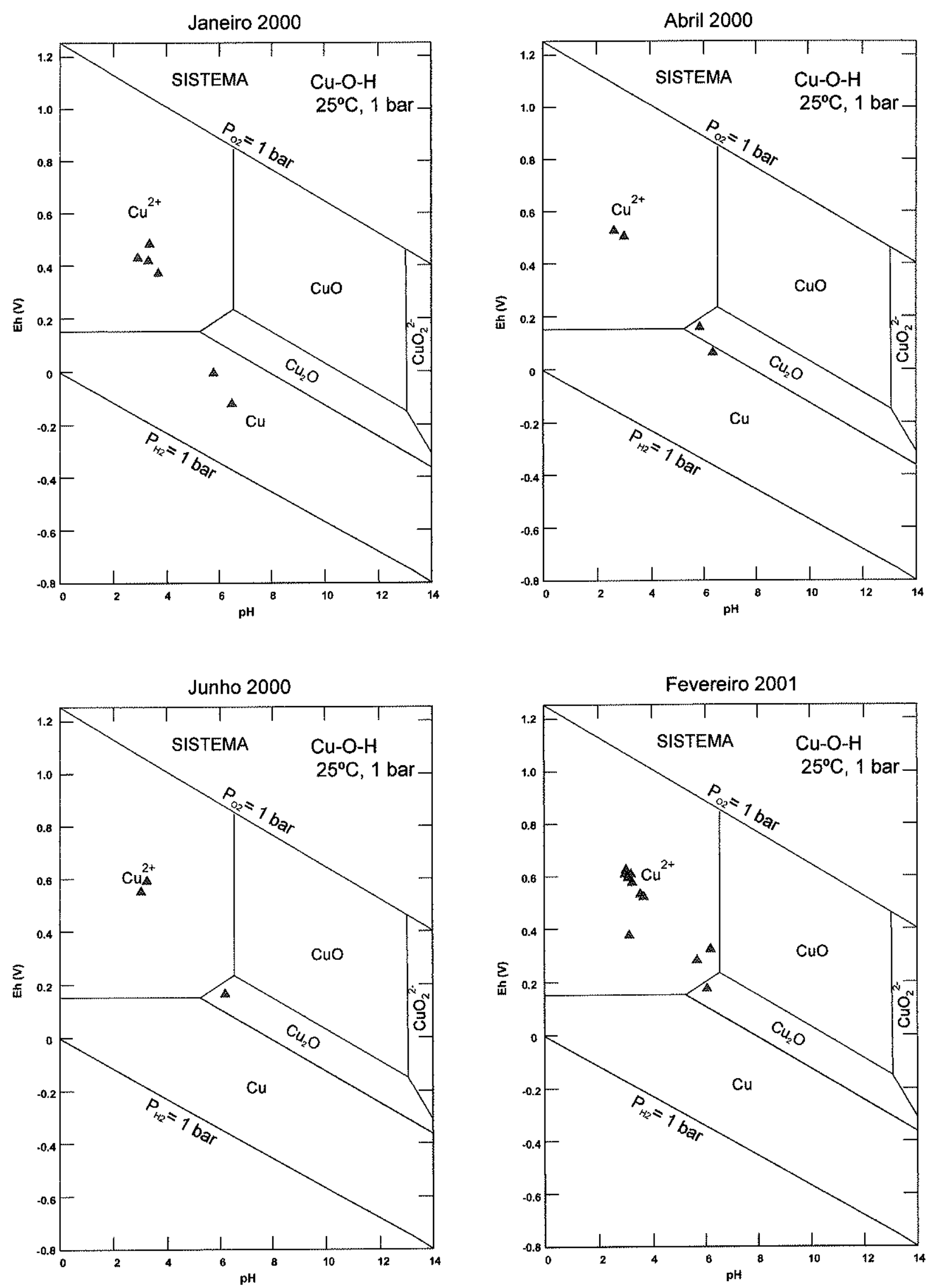

Figura 09 - Diagramas pH-Eh para o sistema Cu-O-H (Brookins, 1988). Os dados plotados referem-se aos poços ativos em cada evento de monitoramento representado. 


\section{Chumbo}

Tabela 16 - Resultados de Chumbo em Água Subterrânea.

\begin{tabular}{|c|c|c|c|c|}
\hline \multirow{3}{*}{$\begin{array}{l}\text { Poco do } \\
\text { Monitoramento }\end{array}$} & \multicolumn{4}{|c|}{ Parametro-chumbo $(\mathrm{Mg} / \mathrm{L})$} \\
\hline & \multicolumn{4}{|c|}{ Data de Evento do Monitoramonto } \\
\hline & Janoiro 2000 & $A 6 r 12000$ & Junho 2000 & fovereiro 2001 \\
\hline$P M-01$ & 1,80 & $* *$ & $* *$ & $\hbar \star$ \\
\hline$P M-02$ & 2,60 & ** & ** & ** \\
\hline$P M-03$ & ** & ** & ** & ** \\
\hline$P M-04$ & * & * & * & * \\
\hline$P M-05$ & * & * & $*$ & $*$ \\
\hline$P M-06$ & $<0,05$ & $<0,05$ & $<0,05$ & 0,12 \\
\hline$P M-07$ & 12,50 & 16,0 & 13,00 & 15,40 \\
\hline$P M-08$ & $<0,05$ & $<0,05$ & $* *$ & 0,14 \\
\hline$P M-09$ & $*$ & $\star$ & * & $*$ \\
\hline$P M-10$ & ** & 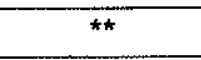 & ** & 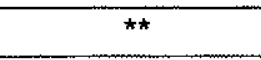 \\
\hline$P M-11$ & 1,80 & 1,40 & 1,70 & 1,58 \\
\hline$P M-12$ & ** & ** & $* *$ & ** \\
\hline$P M-13$ & $* * *$ & $* * *$ & $\star \star \star \star$ & 0,48 \\
\hline$P M-14$ & $\star \star \star \star$ & *k* & $\star * \star$ & $n d$ \\
\hline$P M-15$ & $* * *$ & $* * *$ & $\star \star \star *$ & $n d$ \\
\hline$P M-16$ & $\star * * *$ & 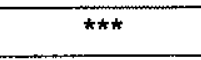 & $* * * *$ & 0,30 \\
\hline$P M-17$ & $\star \star \star \star$ & $* * *$ & $\star * *$ & 0,56 \\
\hline$P M-18$ & $* * *$ & $* * *$ & $* \star * *$ & 6,59 \\
\hline$P M-19$ & $\# * *$ & $\star \star \star \star$ & $* \star *$ & 0,33 \\
\hline
\end{tabular}

"Poço danificado; ** Poço seco; *** Poço ainda não instalado nd - Não detectado, com limite de deteç̧ão de $0,05 \mathrm{mg} / \mathrm{L}$.

Entre os poços com concentrações de chumbo significativas e presentes em todos os monitoramentos, encontram-se somente os PMs 07 e 11. Porém, em função do período relativamente curto, não foi possivel se caracterizar uma tendência para os resultados obtidos em cada poço. Os PMs 01 e 02 apresentaram concentrações importantes no primeiro monitoramento, mas não há medidas posteriores para controle da contaminação no local, sendo o PM-18 o poço mais próximo.

No último monitoramento, o elemento chumbo não foi detectado nos PMs 14 e 15, porém, nos outros nove poços os resultados estão acima do limite, variando entre 12 e 1540 vezes o limite estabelecido pela Portaria 1469, nos PMs 06 e 07 respectivamente. Podem-se distinguir duas plumas para o elemento, em torno dos PMs 07 e 18, limitando-as às proximidades da Rodovia Raposo Tavares e da 
Empresa, respectivamente.

Esta configuração permitiu a interpretação da existência de duas fontes distintas de contaminação por chumbo em água subterrânea, uma primeira fonte (Fonte A) a partir da Empresa em estudo e uma segunda (Fonte B), aparentemente mais importante devido às maiores concentrações, a partir da desativada fábrica de produtos vulcanizados.

As plumas com as faixas de isoconcentrações delimitadas para o chumbo podem ser visualizadas na figura 10.

O comportamento do chumbo na água subterrânea pode ser avaliado pelas condições de Eh e $\mathrm{pH}$ atuantes. A figura 11 apresenta os diagramas $\mathrm{pH}$-Eh para o sistema Pb-S-C-O-H (Brookins, 1988), referentes aos quatro eventos de monitoramento que dispõem destes dados. O número de pontos plotados em cada diagrama refere-se ao número de poços ativos em cada evento.

O diagrama mostra que sob condições redutoras há um extenso campo para a forma PbS. Na ausência de enxofre ou em muito baixa atividade deste elemento, o chumbo nativo $\mathrm{Pb}$ é estável, isto é, há um limite entre $\mathrm{Pb}$ e $\mathrm{PbO}$, que intersecta o eixo com $E h=0,26 \mathrm{~V}$. Na presença de sulfeto e sulfato, ocorre uma estreita faixa para o ion $\mathrm{Pb}^{2+}$ em condições de $\mathrm{pH}$ muito baixos $(<0,4)$. Em ambiente oxidante e ainda ácido (até $\mathrm{pH}=5$ ) ocorre o campo do $\mathrm{PbSO}_{4}$ e sob condições de $\mathrm{pH}$ mais elevado o campo do $\mathrm{PbCO}_{3}$. Para a faixa de $\mathrm{pH}$ mais elevado ocorre a forma $\mathrm{PbO}$ que oxida para $\mathrm{Pb}_{3} \mathrm{O}_{4}$, que por sua vez oxida para $\mathrm{PbO}_{2}$. Sob condições de pouco $\mathrm{C}$ e $S$ dissolvidos, o campo do $\mathrm{Pb}^{2+}$ passa a ser muito maior.

Nas condições de Ph e Eh da água subterrânea do local, o chumbo deveria permanecer estável nas formas de $\mathrm{PbSO}_{4}$ e $\mathrm{PbCO}_{3}$, na presença de $\mathrm{C}$ e $\mathrm{S}$. Isto pode ser observado nos diagramas com os valores de $\mathrm{pH}$ e Eh plotados. Entretanto, com pouco $\mathrm{S}$ e $\mathrm{C}$, o campo do $\mathrm{Pb}^{2+}$ é muito maior, como citado acima, possibilitando a presença de $\mathrm{Pb}$ dissolvido na água subterrânea, o que de fato ocorre na área, de acordo com os resultados obtidos nas análises quimicas. Análises para $S$ e $C$ poderiam confirmar esta afirmação. 


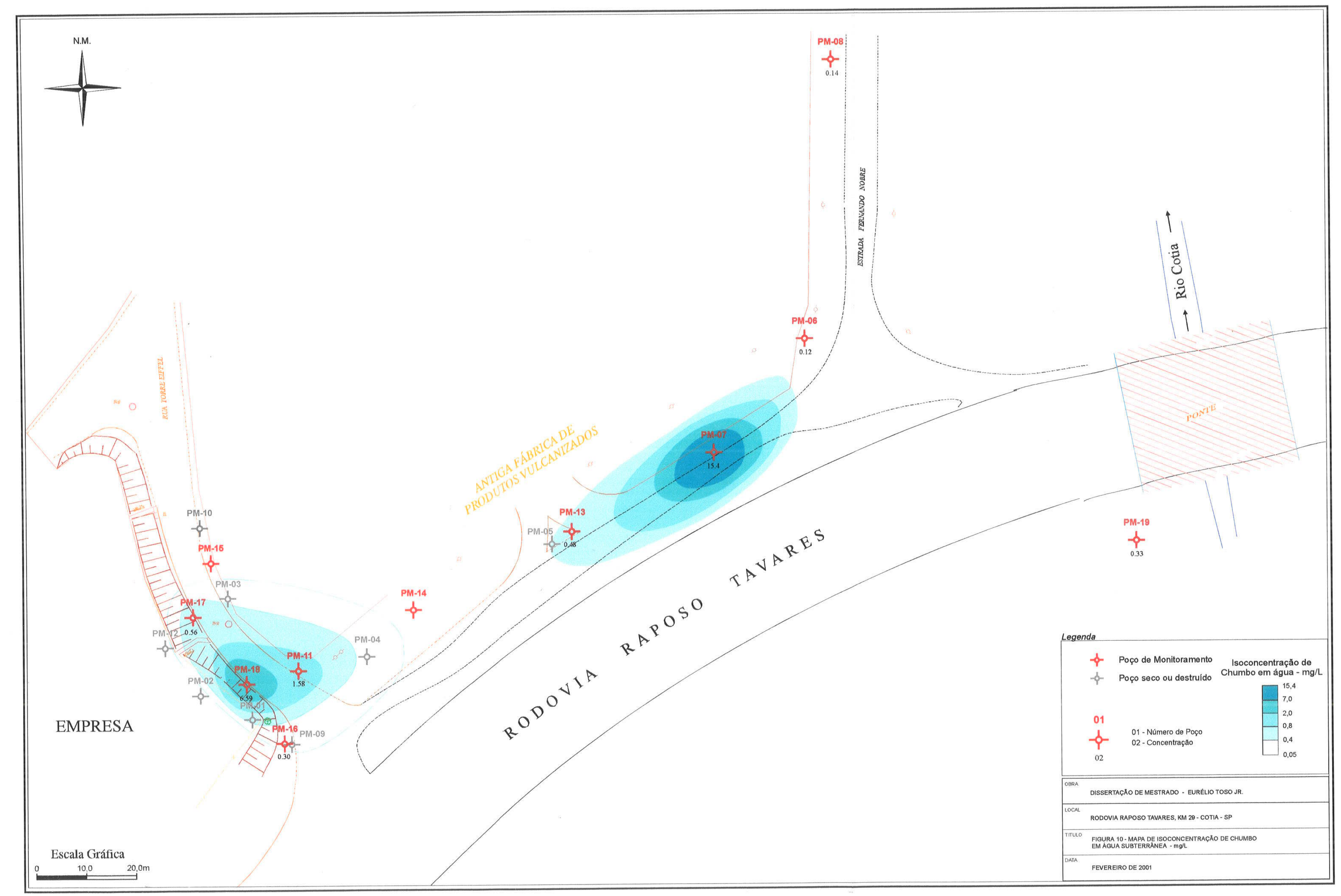



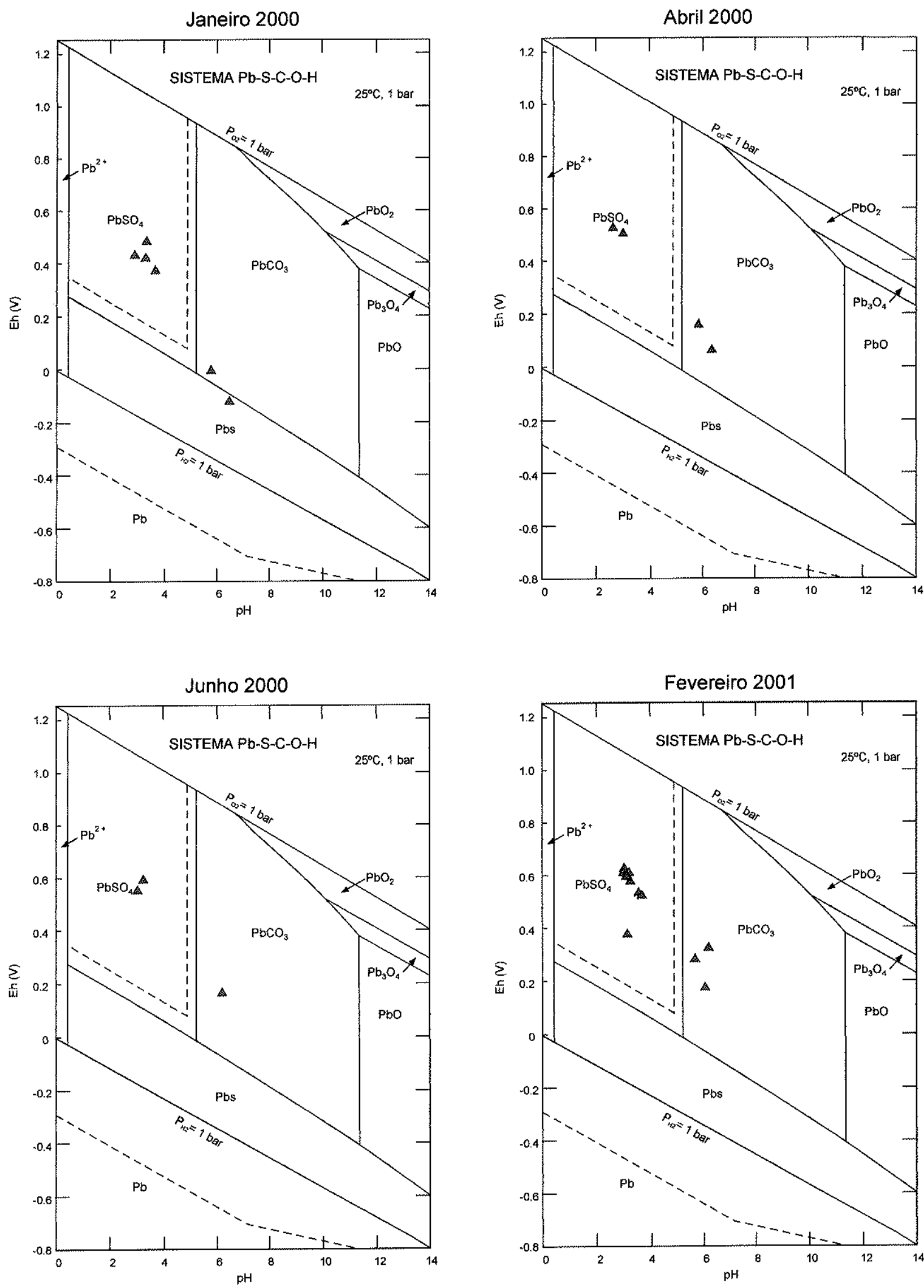

Figura 11 - Diagramas $\mathrm{pH}$-Eh para o sistema $\mathrm{Pb}-\mathrm{S}-\mathrm{C}-\mathrm{O}-\mathrm{H}$ (Brookins, 1988). Os dados plotados referem-se aos poços ativos em cada evento de monitoramento representado. 


\section{Zinco}

Tabela 17 - Resultados de Zinco em Água Subterrânea

\begin{tabular}{|c|c|c|c|c|}
\hline \multirow{3}{*}{$\begin{array}{l}\text { Pogo do } \\
\text { Monitoramento }\end{array}$} & \multicolumn{4}{|c|}{ Parametro - Zlnco $(M g / L)$} \\
\hline & \multicolumn{4}{|c|}{ Data de Evento de Monitoramento } \\
\hline & Janeiro 2000 & Abril 2000 & Junho 2000 & Fevereiro 2001 \\
\hline$P M-01$ & 14,10 & $\star \star *$ & k* & ** \\
\hline$P M-02$ & 20,80 & ** & ** & ** \\
\hline$P M-03$ & $\star *$ & $* \star$ & $\hbar \star$ & ** \\
\hline$P M-04$ & * & * & * & * \\
\hline$P M-05$ & ${ }^{*}$ & ${ }^{*}$ & ${ }^{*}$ & $*$ \\
\hline$P M-06$ & $<0,05$ & $<0,05$ & $<0,05$ & 0,202 \\
\hline$P M-07$ & 42,00 & 54,0 & 57,00 & 58,2 \\
\hline$P M-08$ & $<0,05$ & $<0,05$ & ** & 0,261 \\
\hline$P M-09$ & * & $*$ & * & * \\
\hline$P M-10$ & 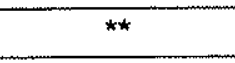 & ** & ** & ${ }^{* \star}$ \\
\hline$P M-11$ & 22,00 & 18,9 & 23,10 & 15,0 \\
\hline$P M-12$ & $* *$ & $\star \star$ & ** & $* *$ \\
\hline$P M-13$ & $\hbar \star \star$ & $\star \star \star \star *$ & 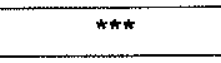 & 23,3 \\
\hline$P M-14$ & $\star \star * *$ & $\star \star \star \star *$ & $\star \star \star \star$ & 16,9 \\
\hline$P M-15$ & $\star \star * \star *$ & $\star \star \star *$ & $\star \star \star *$ & 6,24 \\
\hline$P M-16$ & *** & 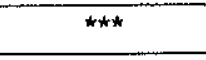 & $* * *$ & 20,7 \\
\hline$P M-17$ & $\star \star \star \star$ & $\star \star \star \star$ & 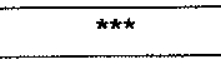 & 19,2 \\
\hline$P M-18$ & $\star \star \star \star$ & $\star \star \star \star$ & $* * *$ & 36,6 \\
\hline$P M-19$ & $\star \star \star \star$ & $\star \star \star \star *$ & $* * *$ & 1,51 \\
\hline
\end{tabular}

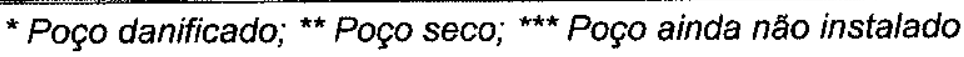

Em relação ao zinco, o mesmo padrão de resultados obtidos para o chumbo foi constatado, com resultados significativos nos PMs 07 e 11 em todos os eventos e, somente no primeiro, para os PMs 01 e 02 . Os PMs 07 e 18, respectivamente, também apresentaram as maiores concentrações, podendo-se notar proporcionalidade nos resultados obtidos para os dois elementos nos poços analisados.

Os PMs 06, 08 e 19 apresentaram concentrações abaixo do limite estabelecido. Entretanto, nos outros oito poços os resultados estão acima do limite, variando entre 1,2 a 11,6 vezes o limite estabelecido, nos PMs 15 e 07 respectivamente. Do mesmo modo que o chumbo, podem-se observar duas plumas distintas, em torno dos PMs 07 e 18. A presença de zinco acima do limite no PM-14 pode ser um indicativo de maior expressão da fonte na área da antiga empresa de produtos vulcanizados ou a presença de mais de uma fonte. 
Entretanto, apesar dos resultados acima, optou-se pela realização da avaliação de risco somente para o chumbo, em função de seu maior potencial de risco.

O mapa com as faixas de isoconcentrações delimitadas para o zinco pode ser visualizado na figura 12.

O comportamento do zinco na água subterrânea pode ser avaliado pelas condições de Eh e pH atuantes. A figura 13 apresenta os diagramas $p H$-Eh para o sistema Zn-O-H-S-C (Brookins, 1988), referentes aos quatro eventos de monitoramento que dispõem destes dados. O número de pontos plotados em cada diagrama refere-se ao número de poços ativos em cada evento.

O diagrama mostra um amplo campo de ZnS em condições redutoras e acima do $\mathrm{pH}$ 2,1. Abaixo deste $\mathrm{pH}$ dissolve para $\mathrm{Zn}^{2+}$, cujo campo se estende para condições de Eh mais elevados, ocupando grande área de Eh e pH, estendendo-se até o $\mathrm{pH} 7,5$, a partir do qual surge estreita faixa de $\mathrm{ZnCO}_{3}$ e uma área um pouco maior de $\mathrm{ZnO}$ sob ambiente um pouco mais básico. Este $\mathrm{ZnO}$ dissolve para $\mathrm{ZnO}_{2}{ }^{2-}$ nos pHs mais elevados. Pode-se observar nos diagramas com os dados plotados que a maioria dos pontos encontram-se no campo do ion $\mathrm{Zn}^{2+}$ e apenas um ponto no campo da forma sólida $\mathrm{ZnS}$. Estes resultados mostram que as condições de pHe Eh na água subterrânea do local, o zinco se mantém estável em sua forma iônica $\mathrm{Zn}^{2+}$.

As configurações determinadas para as plumas de chumbo e zinco, confirmam o modelo hidrogeológico proposto. $O$ modelo confere às plumas de contaminação uma distribuição caracteristica, com maiores concentrações acompanhando inicialmente o lineamento da Rua Torre Eiffel e principalmente ao longo da via de acesso à rodovia, condicionando o fluxo paralelamente à rodovia e rumo ao rio Cotia.

Os resultados de metais obtidos nos PMs 08 e 19 podem indicar outras fontes menores de contaminação, visto que são concentrações mais altas do que as comumente encontradas em águas subterrâneas não contaminadas. 


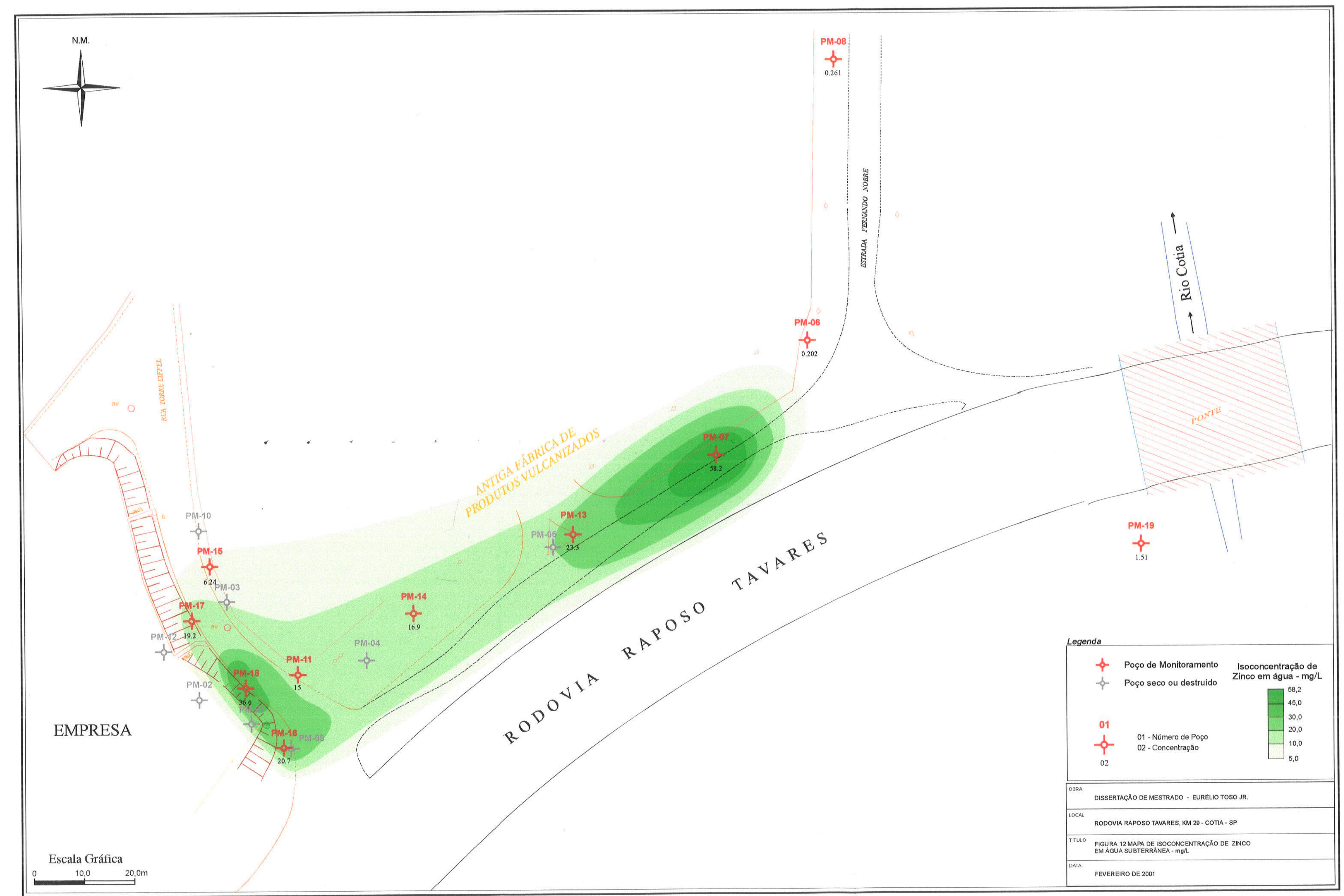



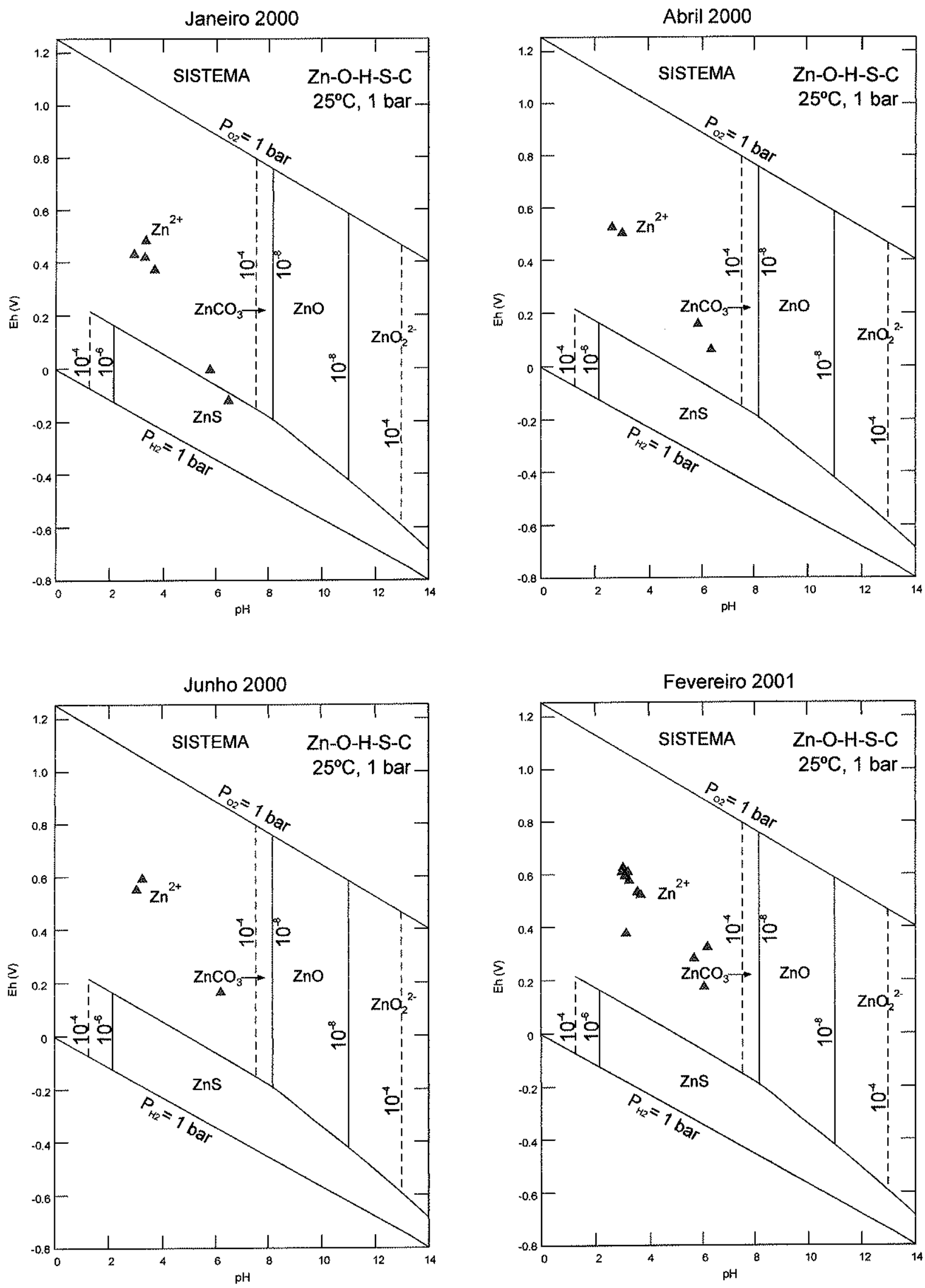

Figura 13 - Diagramas pH-Eh para o sistema $\mathrm{Zn}$-O-H-S-C (Brookins, 1988). Os dados plotados referem-se aos poços ativos em cada evento de monitoramento representado. 


\subsubsection{Aguas Superficiais}

Para avaliação da contribuição do vazamento à drenagem superficial, foi coletada uma amostra do Rio Cotia, a jusante da área contaminada e enviada para análise físico-química.

O trecho estudado do rio é pertencente à Classe 3, conforme Decreto 10755 de 22/11/1977, que dispõe sobre o enquadramento dos corpos de água receptores na classificação prevista no Decreto $8468 / 76$. Tratam-se de águas destinadas ao abastecimento doméstico após tratamento convencional; irrigação de culturas arbóreas, cerealiferas e forrageiras; presenvação de peixes e dessedentação de animais.

A área em avaliação pertence a uma região da Bacia do Rio Cotia denominada Cotia Baixo, que, ao longo do ano de 1999, forneceu para a Estação de Tratamento de Água (ETA) da SABESP - Companhia de Saneamento Básico do Estado de São Paulo, em Barueri, uma média de $1,03 \mathrm{~m}^{3} / \mathrm{s}$ (CETESB, 1999).

Os padrões de qualidade ambiental das águas superficiais são regulamentadas em território nacional pela Resolução CONAMA (Conselho Nacional de Meio Ambiente) $n^{\circ}$ 20/86 e em caráter estadual pelo Decreto $n^{\circ}$ 8468/76. Análises da água do rio Cotia efetuadas pela CETESB ao longo de 1999, em ponto

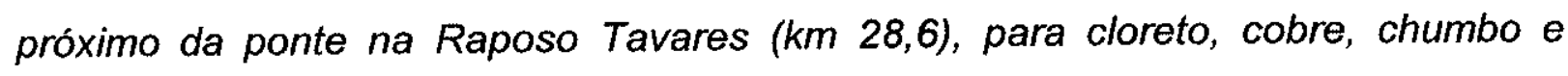
zinco, indicam concentrações dentro dos limites propostos pela resolução CONAMA $n^{\circ}$ 20/86 e Decreto Estadual $n^{\circ}$ 8468/76.

Para os parâmetros avaliados, são apresentados na Tabela 18 os padrões referentes à Classe 3 .

Tabela 18 - Padrões de Qualidade Ambiental - Água

\begin{tabular}{|c|c|c|c|c|c|c|c|}
\hline Parâmetro (Classe 3) & $p H$ & Cond.* & $\begin{array}{l}S T D^{*} \\
(m g / L)\end{array}$ & $\begin{array}{c}\text { Cloreto } \\
m g / L\end{array}$ & $\begin{array}{l}\text { Cobre } \\
(m g / L)\end{array}$ & $\begin{array}{c}\text { Chumbo } \\
\text { (mg/L) }\end{array}$ & $\begin{array}{l}\text { Zinco } \\
(m g / L) \\
\end{array}$ \\
\hline Resolução CONAMA n $n^{2} 20 / 86$ & $6,0-9,0$ & - & 500 & 250 & 0,5 & 0,05 & 5 \\
\hline Decreto Estadual $n^{\circ} 8468 / 76$ & - & - & - & - & 1 & 0,1 & 5 \\
\hline
\end{tabular}

* - Cond. = Condutividade Elétrica; STD = Solidos Totais Dissolvidos 
Das análises realizadas a partir da amostra coletada do Rio Cotia, foram obtidos os valores apresentados na Tabela 19 a seguir:

Tabela 19 - Análises de Águas Superficiais, fevereiro de 1998.

\begin{tabular}{|c|c|c|c|c|}
\hline Amostra & pH & Condutividade (Fs) & $\begin{array}{c}\text { Sol Totals } \\
\text { Dissolvidos } \\
\text { (mg/h) }\end{array}$ & $\begin{array}{c}\text { Cloreto } \\
(\mathrm{mg} / \mathrm{h})\end{array}$ \\
\hline Rio Cotia & 6,99 & 89,1 & 136 & 10 \\
\hline
\end{tabular}

Análises comparativas dos resultados apresentados na Tabela $18 \mathrm{com}$ os resultados da Tabela 19 não detectaram influência do vazamento nas águas do Rio Cotia, uma vez que em relação às águas subterrâneas, as águas superficiais apresentam-se menos ácidas, com menores concentrações de sólidos dissolvidos e cloretos, consequentemente apresentando menor condutividade.

Em relação aos metais, não foram realizadas análises da água, visto que na época desta análise não se sabia da contaminação por metais na água subterrânea. No item de modelagem de transporte são estimadas concentrações de chegada de chumbo em água subterrânea ao rio Cotia. 


\section{AVALIAÇÃO DE RISCO}

Os parâmetros fundamentais à determinação dos riscos associados ao cenário de contaminação estudado foram definidos a partir do guia padrão definido pela ASTM - American Society for Testing and Materials para a metodologia RBCA Risk based Corrective Action e diretrizes expressas no documento CETESB (2000) "Estabelecimento de Valores de Referência de Qualidade e de Intervenção para Solo e Água Subterrânea no Estado de São Paulo.

$\mathrm{Na}$ condução desta avaliação de risco, a estratégia foi de se elaborar primeiramente uma filtragem do risco de forma a aproximar-se dos limites de exposição e riscos através de análises conservadoras, utilizando-se de suposições de exposição ao risco para situações mais prováveis e mais consenvadoras (i.e., maximização da possibilidade de risco através de suposições de exposição para o "pior caso" segundo as normas citadas acima, ou o mais desfavorável).

Para que o risco à saúde exista, três componentes essenciais devem estar presentes concomitante e interativamente, formando o trinômio que compõe a avaliação de risco:

- contaminante(s) presente(s) em concentrações suficientemente altas de forma a serem capazes de suscitar efeitos deletérios à saúde;

- um receptor humano presente apresentando o potencial de experimentar exposição ao risco proveniente do(s) contaminante(s) em questão;

- uma rota de exposição que culmine com a assimilação do contaminante pelo corpo do receptor para que o efeito possa ocorrer.

Concentrações abaixo dos valores de intervenção (l) do Sistema RAI (CETESB, 2001) para solo e valores máximos permitidos (VMP) da Portaria 1469 (Ministério da Saúde, 2000) para água subterrânea foram desconsideradas, enquanto foram consideradas rotas e receptores atuais e futuros, visto que a metodologia permite a utilização de um cenário de presenvação, no qual considerase a possibilidade de um uso futuro diferente do atual.

O desenvolvimento do estudo baseou-se na execução de quatro fases 
principais, que resultaram numa avaliação dos riscos provocados pela exposição ao contaminante que seja cientificamente defensável, descritas na revisão bibliográfica.

No presente caso, configura-se o nível 2 de avaliação de risco (Tier 2) de acordo com a norma ASTM PS104-98. Esta etapa envolve o uso de modelos matemáticos relativamente simples, conforme ilustrado na descrição do modelo, quando da caracterização do risco.

\subsection{Formulação do Problema}

A formulação do problema para avaliação de risco na área envolve a caracterização de rotas de contaminação em água subterrânea e solo, em todas as suas possiveis rotas de exposição ao contaminante.

Para a exposição de um indivíduo receptor ao solo contaminado, consideraram-se as rotas de ingestão e contato dermal com este solo, admitindo-se a exposição de pessoas que circulam na área de sua ocorrência, não impermeabilizada, permitindo o contato direto com o solo.

Atualmente, não existem rotas que possam expor receptores ao contato com a água subterrânea contaminada, uma vez que não existem poços cadastrados ou conhecidos no local. Contudo, o critério adotado pela CETESB para a adoção de padrões de intervenção, baseou-se na presenvação deste recurso para a sua utilização pela população atual ou futura, independentemente do uso e ocupação atuais.

Desta forma, uma mudança no cenário em função da crescente ocupação na região, ou seja, com a captação de água subterrânea para consumo humano, implica na necessidade de avaliação de risco para o novo cenário, uma vez que a chegada do contaminante em possiveis receptores é uma função do tempo, como pode ser observado na simulação de transporte.

Em relação ao rio Cotia, não houve a identificação de captação da água do rio para consumo ou qualquer outro tipo de uso em pontos próximos da área avaliada, mas sabe-se da existência de moradores ribeirinhos a jusante do local (alguns quilômetros) que fazem uso da água. Foram efetuadas simulações de 
transporte para estimativa de concentrações de chegada de contaminante ao rio.

Entretanto, estas concentrações são relativas ao coontaminante em água subterrânea, sendo que, com o aporte desta água ao rio, há uma diluição da concentração, fator desconsiderado nesta pesquisa, não sendo realizada estimativa de risco com o rio como receptor.

Assim, a avaliação de risco em relação à água contaminada baseia-se num cenário hipotético de uso futuro da água subterrânea, visto que os modelos permitem tal abordagem, caracterizando-se as rotas relacionadas à ingestão $e$ contato dermal com água subterrânea contaminada.

As rotas de inalação de compostos voláteis a partir do solo e água subterrânea foram desconsideradas, em função da pressão de vapor nula do chumbo. Considerações mais detalhadas a respeito das rotas de exposição podem ser vistas na próxima página.

Os resultados indicam contaminação de água com concentrações acima dos valores de intervenção e limite máximo permitido estabelecidos pela CETESB e Portaria 1469, respectivamente, para os metais chumbo e zinco em vários poços instalados (Tabelas 16 e 17), e, em solo, para o chumbo na amostra AS-23 (Tabela 09).

O chumbo foi considerado como contaminante de interesse, de acordo com o histórico da indústria, sistemas de disposição de efluentes e concentrações apresentadas. Chumbo é classificado pela USEPA como pertencente à classe $B 2 \Rightarrow$ Provavelmente Carcinogênico, com evidências suficientes de estudos em animais e evidências epidemiológicas limitadas ou nulas, enquanto o zinco é classificado pela USEPA como classe $D \Rightarrow$ não classificado como cancerígeno ao homem. Características toxicológicas do chumbo e do zinco estão apresentadas no item 6.2 .

O cenário a ser considerado é hipotético, de uso futuro em relação à água subterrânea e atual em relação ao solo, frente aos valores de exposição default definidos pela CETESB ou norma ASTM-RBCA, porém serão feitas considerações sobre uma frequência real de exposição no local. A exposição será considerada contínua, visando uma análise conservadora dos impactos causados. 


\subsubsection{Rotas relacionadas à contaminação em água}

\subsubsection{Ingestão de água contaminada}

O único ponto receptor identificado atualmente, que permite a existência desta rota é o rio Cotia, localizado a jusante da área da empresa, porém não foram identificados quaisquer pontos de captação de água do rio para consumo, apesar de se saber da presença de populações ribeirinhas ao rio a jusante da área. Embora não tenham sido cadastradas fontes de captação de água subterrânea, a presença de concentrações dos metais $\mathrm{Pb}$ e $\mathrm{Zn}$ em vários $\mathrm{PMs}$, acima do valor de intervenção da CETESB e/ou do valor máximo permitido estabelecido pela Portaria 1469, indica a avaliação de risco como atitude preventiva e que as únicas ações interventoras imediatas a serem recomendadas são o não consumo da água subterrânea na área e o monitoramento periódico dos poços instalados.

Para um cenário de uso e ocupação futuro da área, apresenta-se uma estimativa de riscos para possíveis pontos de captação, a partir das simulações realizadas, em pontos de exposição (receptor) e tempos variados.

$E$ apresentada uma modelagem de transporte, desde as fontes $A$ (Empresa) e $B$ (Fábrica de Produtos Vulcanizados), estimadas a partir dos PMs 18 e 07, que apresentaram focos principais com concentrações de chumbo, até o Rio Cotia e hipotéticos pontos futuros de exposição.

\subsubsection{Contato dermal com água contaminada durante o banho}

Para a avaliação do risco associado ao contato dermal com a água subterrânea contaminada ocorre a mesma situação existente em relação à ingestão, na qual realizou-se a avaliação de risco considerando um cenário futuro de consumo. 


\subsubsection{Rotas relacionadas à contaminação em solo}

\subsubsection{Contato dermal com solo contaminado}

A área sofreu intensa modificação antrópica superficial, uma vez que possui vias de acesso peneplanas e íngremes, com freqüentes obras de temaplenagem, deposição de brita e execução do asfalto. De qualquer modo, a amostra de solo AS-23 foi coletada em local adjacente à impermeabilização, em uma profundidade próxima á superficie, de forma a garantir-se que não tenha sido solo transportado.

A avaliação de nisco foi feita para um cenánio consenvador, que senia a exposição de um receptor nesta área, que hoje é um local onde deveria ser o passeio público e se encontra recoberta por vegetação rasteira e arbustiva, que dificultam o trânsito de pessoas.

Por serem áreas não impermeabilizadas, com circulação de transeuntes, a exposição do contaminante a eventuais receptores pode ocomer pelo contato com o solo contaminado, devendo ser considerada esta rota para efeito de avaliação de risco.

\subsubsection{Ingestão de solo contaminado}

As mesmas considerações aplicadas à rota de contato dermal com o solo contaminado podem ser aplicadas para a ingestão de solo, devendo ser considerada para efeito de avaliação dos riscos associados.

\subsection{Avaliação da Exposição e Toxicidade}

Em relação ao ingresso de contaminante no organismo de um indivíduo receptor através das rotas de contato dermal e ingestão de solo, considerou-se o cenário atual, utilizando-se a maior concentração de chumbo na área (AS-23), baseado nas últimas análises químicas de solo.

Para esta concentração encontrada em solo sub-superficial determinada na profundidade amostrada $(0,50 \mathrm{~m})$, a avaliação levou em consideração que é a concentração de exposição no ponto de contato direto de um eventual receptor com 
o solo, não sendo considerada a antropização (terraplenagem, movimento de terra, etc.) sofrida pela área e geradora de diferenças superficiais, que é parcialmente pavimentada e permite o contato direto com o solo onde foram identificadas concentrações de chumbo.

Estes fatores dão um caráter conservador à avaliação. A circulação de pessoas e, fundamentalmente de crianças, potencializa o contato dermal com o solo e a ingestão acidental deste.

As últimas análises de solo dentro da área da empresa não indicaram resultados de contaminação em chumbo, que impusessem a necessidade de avaliação de risco, lembrando-se que grande parte de solo no local foi removido quando do vazamento de ácido clorídrico.

Para o ingresso de contaminante através da água, foram consideradas as rotas de contato dermal e ingestão de água, em um cenário futuro de uso e ocupação possivel com utilização de água subterrânea como fontes de captação, mesmo que para o cenário atual pareça improvável a construção de poço(s) de captação na área para uso nobre.

Os valores de exposição adotados são os indicados como mais prováveis, em niveis de exposição usual e conservadora, por CETESB (2000) e USEPA. As concentrações utilizadas foram as definidas pelas simulações de transporte realizadas, das fontes até os receptores.

Foi considerado como ponto de exposição um único receptor humano que estivesse sujeito à exposição constante na área. Todos os parâmetros considerados foram assumidos como usuais (mais comuns) e conservadores (pior caso). A Tabela 20 ilustra os parâmetros caracterizados para uma análise deterministica de risco. 
Tabela 20 - Parâmetros utilizados para Simulações de Riscos por Análise Deterministica, Modificado de API-DSS (1994) e CETESB (2000).

\begin{tabular}{|c|c|c|c|}
\hline \multirow{2}{*}{ Parâmetro } & \multirow{2}{*}{ Unidade } & \multicolumn{2}{|c|}{ Valor Adotado* } \\
\hline & & Usual** & Conservador \\
\hline \multicolumn{4}{|l|}{ Comum à todas as rotas } \\
\hline Peso do Corpo & [Kg] & \multicolumn{2}{|c|}{60 (Adulto) } \\
\hline Expectativa de Vida & [anos] & \multicolumn{2}{|c|}{64} \\
\hline \multicolumn{4}{|l|}{ Ingestão de Água } \\
\hline Duração da Exposição & [anos] & $\begin{array}{l}9 \text { (Adulto) } \\
6 \text { (Criança) }\end{array}$ & $\begin{array}{l}30 \text { (Adulto) } \\
6 \text { (Criança) }\end{array}$ \\
\hline Frequência da Exposição & [dias/ano] & 350 & 365 \\
\hline Razăo de Ingestão & [litros/dia] & $\begin{array}{l}1,4 \text { (Adulto) } \\
1 \text { (Criança) }\end{array}$ & $\begin{array}{c}2 \text { (Adulto) } \\
1,5 \text { (Criança) }\end{array}$ \\
\hline Biodisponibilidade & {$[\mathrm{mg} / \mathrm{mg}]$} & \multicolumn{2}{|r|}{$x^{2}-1$} \\
\hline \multicolumn{4}{|l|}{ Contato Dermal Durante o Banho } \\
\hline Duração da Exposição & [anos] & $\begin{array}{l}9 \text { (Adulto) } \\
6 \text { (Criança) }\end{array}$ & $\begin{array}{l}30 \text { (Adulto) } \\
6 \text { (Criança) }\end{array}$ \\
\hline Frequéncia da Exposição & [dias/ano] & 350 & 365 \\
\hline Tempo de Exposição & [horas/dia] & 0,12 & 0,333 \\
\hline Área Total da Superficie da Pele & {$\left[\mathrm{cm}^{2}\right]$} & \multicolumn{2}{|c|}{$\begin{array}{l}16600 \text { (Adulto) } \\
9500 \text { (Criança) }\end{array}$} \\
\hline Coeficiente de Permeabilidade & [cm/hora] & \multicolumn{2}{|c|}{$4 \times 10^{-6}$} \\
\hline \multicolumn{4}{|l|}{ Contato Dermal com o Solo } \\
\hline Duração da Exposição & [anos] & $\begin{array}{l}9 \text { (Adulto) } \\
6 \text { (Criança) }\end{array}$ & $\begin{array}{l}9 \text { (Adulto) } \\
6 \text { (Criança) }\end{array}$ \\
\hline Freqüência da Exposição & [dias/ano] & 10 & 350 \\
\hline $\begin{array}{c}\text { Área da Superficie da Pele (braços e } \\
\text { mãos) }\end{array}$ & {$\left[\mathrm{cm}^{2}\right]$} & \multicolumn{2}{|c|}{3120 (Adulto) } \\
\hline Fator de Aderência & {$\left[\mathrm{mg} / \mathrm{cm}^{2}\right]$} & \multicolumn{2}{|c|}{0,6} \\
\hline Coeficiente de Absorção & {$[\mathrm{mg} / \mathrm{mg}]$} & \multicolumn{2}{|c|}{0,01} \\
\hline \multicolumn{4}{|l|}{ Ingestão de Solo } \\
\hline Duração da Exposição & [anos] & $\begin{array}{l}9 \text { (Adulto) } \\
6 \text { (Criança) }\end{array}$ & $\begin{array}{l}9 \text { (Adulto) } \\
6 \text { (Criança) }\end{array}$ \\
\hline Freqüencia de Contato com o Solo & [dias/ano] & 10 & 350 \\
\hline Razão de Ingestão de Solo & [mg/dia] & \multicolumn{2}{|c|}{$\begin{array}{l}200 \text { (Criança) } \\
100 \text { (Adulto) }\end{array}$} \\
\hline Fração de Solo Contaminado & {$[m g / m g]$} & \multicolumn{2}{|c|}{1} \\
\hline Biodisponibilidade & {$[\mathrm{mg} / \mathrm{mg}]$} & \multicolumn{2}{|c|}{1} \\
\hline \multicolumn{4}{|l|}{ Dados Toxicológicos do Chumbo } \\
\hline Fator de Potência & $\mathrm{kg}-\mathrm{dia} / \mathrm{mg}$ & \multicolumn{2}{|c|}{ Não definido } \\
\hline Ingresso Diário Tolerável & $m g / k g-d i a$ & \multicolumn{2}{|c|}{$3,6 \times 10^{3}$} \\
\hline Concentração no solo & $m g / k g$ & \multicolumn{2}{|c|}{409} \\
\hline Concentração na água & $m g / L$ & \multicolumn{2}{|c|}{ simulação } \\
\hline
\end{tabular}

* - Valores de Referência sugeridos por CETESB elou USEPA.

** - Como usual deve-se entender freqüente / provável de acontecer. 
Chumbo é um elemento de ocorrência natural, causador de diversos e severos danos à saúde. O comportamento no corpo humano é semelhante ao cálcio, acumulando-se nos ossos, sendo que na ocorrência de uma deficiência de cálcio, o chumbo pode-se alastrar pela corrente sangüínea. Quando absorvido pelo homem, pode causar anemia, danos ao sistema nervoso, produção de células sangüineas, reprodução, acelera a destruição de glóbulos vermelhos (Harte et al, 1991).

De uma maneira geral, para a população adulta não fumante, a principal rota de exposição é através da ingestão de águas e alimentos. Para crianças, ingestão de solo aparece como rota também (CETESB, 2000).

Os primeiros sintomas referentes a efeitos agudos são fadiga, anemia e desordens neurológicas. Conforme nivel e duração da exposição, o chumbo pode resultar em efeitos desde subcelulares a mal funcionamento geral do organismo, de inibição de enzimas a mudanças morfológicas e até a morte. Os efeitos crônicos produzem sintomas de perda de apetite, constipação, anemia, fraqueza, cólicas, dores musculares e nas juntas, hipertensão, disfunção renal, más formações congênitas, diminuição da quantidade de esperma e danos aos sistemas nervosos periférico e central (CETESB, 2000).

O zinco não é considerado um elemento cancerígeno. A principal via de exposição humana é a ingestão, que, quando superior a $72 \mathrm{~g}$ produz sintomas de febre, diarréia, vômitos e outras irritações gastrointestinais. Em exposição ocupacional os trabalhadores podem mostrar distúrbios gastrointestinais e disfunções do fígado (CETESB, 2000).

\subsection{Caracterização do risco}

A USEPA não possui dados referentes aos parâmetros FP e DRf em relação ao chumbo. Segundo a USEPA existem estudos que indicam o potencial cancerígeno do chumbo no organismo humano, porém com dados insuficientes para a adoção de valores específicos para cada parâmetro.

A quantificação do risco de efeitos cancerígenos envolvem muitas incertezas, algumas das quais podem ser únicas para chumbo. Idade, saúde, estado nutricional, 
corpo e duração da exposição influenciam a absorção, liberação e excreção do chumbo. Além disso, o conhecimento atual farmacocinético do chumbo indica que uma estimativa derivada dos procedimentos padröes não descreveriam o real potencial de risco. Assim, o "Grupo de Avaliação Cancerígena" recomenda que uma avaliação numérica não seja utilizada (USEPA-IRIS, 2001).

Assim, o próprio modelo assume valores iguais a 1 para os parâmetros sem dados existentes e executa o programa, apresentando a estimativa do risco (Anexo 04). Esta situação fragilizaria a qualidade dos resultados de riscos cancerigenos calculados pelo método, optando-se pela não realização destes cálculos de risco, ou seja, desconsiderar os resultados de risco baseados no FP assumido pelo modelo.

Em relação aos efeitos não cancerígenos, o parâmetro DRf foi substituído pelo IDT - Ingresso Diário Tolerável, que possui valor regulamentado para o chumbo. Este é o parâmetro no qual baseia-se o sistema RAI (CETESB, 2000).

$O$ quociente de risco $Q R$, calculado para os efeitos não cancerígenos de um composto, quando maior que 1 indica a ocorrência de risco à exposição ao composto pela rota avaliada e quando menor que 1 indica a ausência de risco.

Para a realização das estimativas de risco em solo, utilizou-se a concentração específica como dado de entrada no modelo. Para as estimativas de risco em água, antes dos cálculos de risco propriamente ditos, realizaram-se modelagens de transporte de água subterrânea, através de calibração de um modelo de transporte e simulações de transporte até os receptores.

\subsubsection{Modelagem de Transporte}

Através da utilização das informações levantadas na caracterização hidrogeológica da área e da elaboração do modelo hidrogeológico conceitual, para entendimento dos processos de transporte atuantes nos cenários de contaminação identificados na área em avaliação, foram efetuadas simulações com o auxílio do modelo AT 123D.

Como citado anteriormente, adotou-se o chumbo como contaminante de interesse para as simulações, não tendo sido considerado decaimento do elemento, difusão molecular ou qualquer atenuante bioquímico que propicie a redução de 
massa ao longo do tempo. Assim, os dados iniciais de alimentação do modelo foram selecionados de forma conservadora, ou seja, definindo uma situação crítica para o transporte do contaminante.

O cálculo do fator de retardamento $(R)$ conforme equação 04, considerandose coeficiente de distribuição $\mathrm{Kd}=2400 \mathrm{~L} / \mathrm{kg}$ segundo CETESB (2000), proporciona $R=24001$, ou seja, com o chumbo totalmente adsorvido e imóvel. Entretanto, os resultados indicam outro comportamento, demonstrado pelas altas concentrações de chumbo que atingiram a zona saturada e migraram através do fluxo subterrâneo.

Assim, como não há informações para estimativa desta adsorção, optou-se por um modelo sem retardamento. Porém, esta desconsideração de retardamento na velocidade de transporte do soluto em relação à velocidade advectiva da água subterrânea, pode ser significativa para o chumbo, visto ser um elemento de forte adsorção ao solo.

Em adição, como pode ser observado no mapa de isovalores de pH em água subterrânea (Figura 06), no PM-06 e certamente na faixa entre este poço e o rio (pode-se adotar PM-19 como ponto de comparação), as condições são de um ambiente próximo de neutro, com pHs próximos de 6,0, o que cria um ambiente de menor mobilidade para metais, possibilitando uma diminuição no avanço das plumas ou mesmo interrupção deste avanço, se mantida esta faixa de $\mathrm{pH}$. Tal possibilidade não foi considerada nas simulações de transporte realizadas.

\subsubsection{Calibração do modelo}

Para calibrar o modelo AT123D utilizado para a simulação de transporte do contaminante chumbo em água subterrânea, adotaram-se os poços de monitoramento PM-18 e PM-11 como referência inicial, baseando-se no maior e melhor número de informações disponiveis nas proximidades destes poços, como número de poços instalados, quantidade de análises químicas, número de informações hidrogeológicas, que geraram dados mais seguros para a calibração do modelo.

Como não há informações precisas ou mesmo confiáveis a respeito da fonte original, denominada fonte $A$, a partir de antigo tanque de efluentes da indústria, considerou-se inicialmente o PM-18 como fonte atual secundária e o PM-11 como 
receptor. Para a estimativa da dimensão desta fonte, admitiu-se a área de influência delimitada pela concentração máxima obtida no PM-18 como fonte de contaminação, a partir do qual uma pluma de contaminação foi delimitada. Assim, admitindo-se para a área uma forma de elipse, calculou-se uma área de $69 \mathrm{~m}^{2}$. Como espessura desta fonte admitiu-se a lâmina d'água no filtro do poço, ou seja $1,6 \mathrm{~m}$, proporcionando um volume de $110 \mathrm{~m}^{3}$. Esta estimativa é necessária para a entrada de dados de geometria da fonte no modelo.

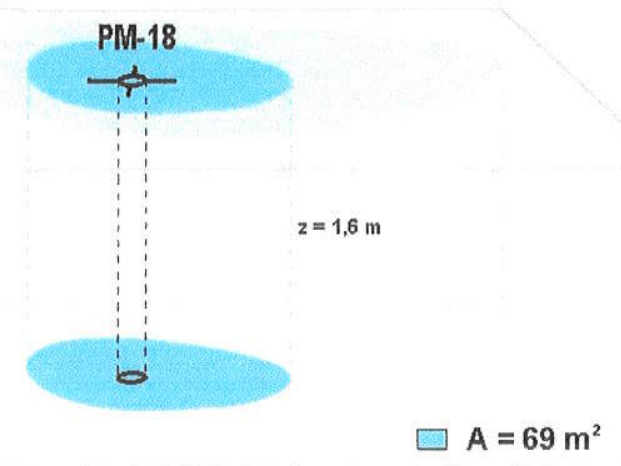

Figura 14 - Visualização tridimensional de fonte secundária assumida em torno do PM-18.

Para a estimativa de massa do contaminante, multiplicou-se o volume estimado pela concentração no poço $(6,59 \mathrm{mg} / \mathrm{L})$ e pela porosidade efetiva $\left(\eta_{e}=0,18\right)$, para cálculo da massa de contaminante transportada, gerando uma massa de 0,131 kg de chumbo, conforme equação abaixo:

$$
m=10^{-3} \cdot C_{P M-18} \cdot V \cdot n_{e} \quad \text { (equação 14) }
$$

Onde :

$$
\begin{aligned}
& 10^{-3}=\text { fator de conversão } \\
& m=\text { massa de contaminante liberada }[\mathrm{kg}] \\
& C_{P M-18}=\text { concentração de chumbo no poço [mg/L] } \\
& V=\text { volume estimado da fonte }\left[\mathrm{m}^{3}\right] \\
& \eta_{e}=\text { porosidade efetiva }[-]
\end{aligned}
$$

Esta massa estimada para a fonte de chumbo, refere-se à quantia de chumbo na zona saturada, desconsiderando-se qualquer possível massa do contaminante retida na zona não saturada. 
A velocidade de transporte advectivo para o local foi calculada em 4,3 m/ano $e$ a distância entre os poços em $11 \mathrm{~m}$. Ao realizar-se a simulação de transporte de contaminante utilizando-se esta massa, a concentração obtida para o tempo de 2,55 anos (tempo necessário para o transporte advectivo entre os poços), observou-se que a concentração no PM-11 obtida na simulação era em torno de 8 \% diferente da detectada em análise química, mostrando um modelo bem ajustado para esta simulação.

Para a estimativa da massa na fonte original, considerada instantânea sem acréscimo de massa de contaminante, inclusive a partir do solo, utilizou-se o mesmo raciocínio. A partir da distância de $15 \mathrm{~m}$ entre a fonte $A$ e o PM-18, calculou-se em 3,5 anos o tempo de transporte advectivo e então simularam-se transportes, por tentativa e erro, para determinar que massa de contaminante proporciona a concentração de chumbo em água obtida no PM-18. A massa determinada para a fonte original foi de $0,76 \mathrm{~kg}$ de chumbo.

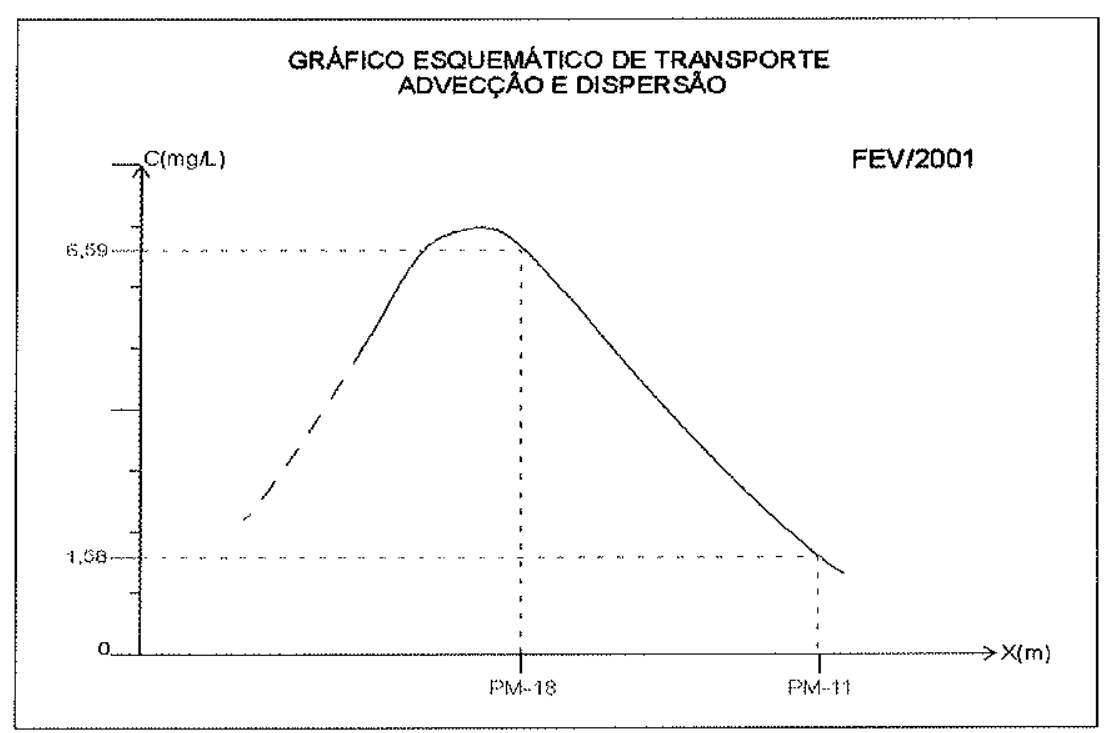

Figura 15 - Gráfico esquemático de transporte advectivo-dispersivo entre PM-18 e PM-11.

As curvas do gráfico acima mostram esquematicamente que a concentração detectada no PM-18 no evento de monitoramento de fevereiro de 2001 está bastante próxima da concentração máxima esperada para o poço conforme a simulação (7,06 mg/L), indicando também que o momento de maior concentração para os PMs 11 e 18 ainda não teriam sido atingidos. Simulação efetuada para 
transporte da fonte original para o PM-11 indica uma concentração máxima esperada para o poço de $2,42 \mathrm{mg} / \mathrm{L}$. Eventos trimestrais de monitoramento são recomendáveis para confirmação das premissas assumidas ou ajustes que se façam necessários ao modelo de calibração.

Somente o PM-11 possui quatro eventos de monitoramento com análises químicas realizadas e os resultados obtidos não permitem a configuração de uma curva ou mesmo tendência, mesmo porque estes eventos estendem-se por apenas um ano de monitoramento, tempo insuficiente para uma comparação com o modelo, além de não se considerar qualquer desvio quanto à precisão e qualidade dos resultados das análises.

Para a calibração em relação ao PM-07, partiu-se da hipótese da caracterização de uma fonte instantânea, sem acréscimo de massa há cinco anos, tempo mínimo conhecido como de desativação da indústria estabelecida no local, não se conhecendo qualquer informação da localização da fonte, em função de não ter sido possivel o acesso às dependências da indústria. Assim, a partir deste tempo e considerando-se uma velocidade de transporte advectivo para o local (2,2 m/ano) estimou-se em $11 \mathrm{~m}$ a distância da fonte original, denominada fonte $B$.

Esta solução reflete parcialmente o quadro real ocorrido na área, visto que a concentração de chumbo detectada no PM-13 deve-se referir provavelmente à mesma fonte, que pode ser maior e mais distante, ou até mesmo mais de uma fonte. Entretanto, a solução simula o aporte de massa de contaminante a montante do poço (PM-07), mas distribuída ao longo de um trecho mais curto.

Para a estimativa da massa nesta fonte, a partir dos dados acima simularamse transportes, por tentativa e erro, para determinar que massa de contaminante proporciona a concentração de chumbo em água, detectada no PM-07, obtendo-se massa de $1,25 \mathrm{~kg}$ de chumbo. Do mesmo modo que na fonte anterior, foi desconsiderada a massa de chumbo retida no solo (zona não saturada), estimandose somente a massa da fonte secundária na zona saturada. 
Para a estimativa da dimensão da fonte secundária em torno do PM-07, admitiu-se a área de influência delimitada pela concentração máxima obtida no poço, a partir do qual uma pluma de contaminação foi delimitada. Assim, admitindose para a área uma forma de elipse, calculou-se uma área de $113 \mathrm{~m}^{2}$. Como espessura desta fonte admitiu-se a lâmina d'água no filtro do poço, ou seja 1,2 m, proporcionando um volume de aproximadamente $135 \mathrm{~m}^{3}$. Esta estimativa é necessária para a entrada de dados de geometria da fonte original (fonte B) no modelo.

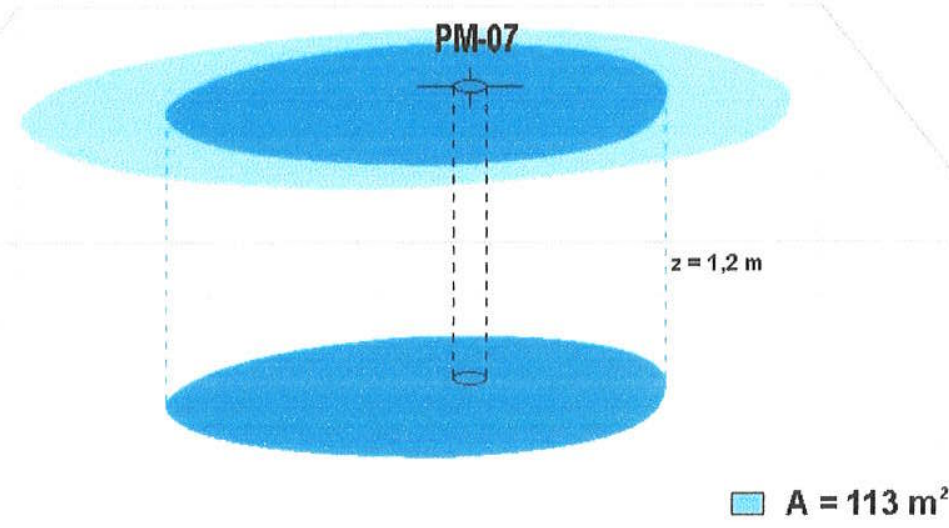

Figura 16 - Visualização tridimensional de fonte secundária assumida em torno do PM-07.

Assim como no PM-11, no PM-07 também foram realizados quatro eventos de monitoramento com análises químicas e os resultados obtidos também não permitem a configuração de uma curva ou mesmo tendência, em função do curto período de um ano de monitoramento, tempo insuficiente para uma comparação com as curvas geradas pelo modelo.

Ressalta-se que esta área não fazia parte do escopo inicial dos trabalhos, entretanto, em função da alta concentração obtida no PM-07, fez-se necessária a inclusão desta área nas simulações de transporte e principalmente avaliação de risco. 
Para a entrada de dados específicos do meio foram utilizados os resultados obtidos no item 5.4, referente à caracterização hidrogeológica, conforme tabela 22.

Alguns parâmetros básicos de referência (default) recomendados na metodologia ASTM-RBCA, estão apresentados na tabela 21 abaixo.

Tabela 21 - Parâmetros de referência utilizados para calibração do modelo.

\begin{tabular}{|c|c|c|}
\hline Parâmetros & Unidade & Valor adotado \\
\hline Dados especificos do meio & \multicolumn{2}{|c|}{} \\
\hline Distância longitudinal $-x$ & $m$ & - \\
\hline Dispersividade longitudinal $-\alpha_{x}$ & $m$ & $\alpha_{x}=0,1 x$ \\
\hline Dispersividade transversal $-\alpha_{y}$ & $m$ & $\alpha_{y}=0,33 \alpha_{x}$ \\
\hline Dispersividade vertical $-\alpha_{z}$ & $m$ & $\alpha_{z}=0,05 \alpha_{x}$ \\
\hline Densidade (solo seco) & $\mathrm{g} / \mathrm{cm}^{3}$ & 1,8 \\
\hline Fração de Carbono Orgânico & - & 0,01 \\
\hline
\end{tabular}

Os dados de entrada no modelo, referentes às dimensões das fontes originais, são baseados nas dimensões estimadas para as fontes assumidas secundárias, em torno dos PMs 18 e 07. A partir das dispersividades adotadas ( $\alpha_{x}$, $\alpha_{y}$ e $\alpha_{z}$ ) para cada trecho advectivo simulado (eixo $x$ ), estimou-se a dimensão de fonte original que proporcionaria aquela dimensão de fonte secundária.

Em relação à geometria dos receptores, foram consideradas as coordenadas $x$ e y de cada poço receptor em relação à fonte e como dimensão no eixo z a lâmina d'água em cada poço.

O modelo simula a liberação de massa de contaminante de modo instantâneo, entretanto, a provável liberação de contaminante para o aqüífero antes da data simulada pode impor diferenças entre concentrações detectadas em análises e resultados esperados a partir da simulação, que devem ser calibrados de acordo com os eventos de monitoramentos futuros. 
Tabela 22 - Parâmetros utilizados para calibração do modelo.

\begin{tabular}{|c|c|c|c|c|c|}
\hline \multicolumn{6}{|c|}{ Dados para Calibraçáo do Modelo } \\
\hline Parâmetros & Unidade & $\begin{array}{c}\text { Fonte A } \\
\text { PM-18 }\end{array}$ & $\begin{array}{c}\text { Fonte A } \\
\text { PM-11 }\end{array}$ & $\begin{array}{l}P M-18 \\
P M-11\end{array}$ & $\begin{array}{l}\text { Fonte B } \\
\text { PM-07 }\end{array}$ \\
\hline \multicolumn{6}{|l|}{ Controle } \\
\hline Aquilfero infinito (eixo y) & $m$ & \multicolumn{4}{|c|}{ Sim } \\
\hline Infinito (eixo z) & $m$ & \multicolumn{4}{|c|}{ Năo } \\
\hline Tipo de Fonte & - & \multicolumn{4}{|c|}{ Instantánea } \\
\hline Tempo de Simulação & anos & \multicolumn{4}{|c|}{50 anos } \\
\hline \multicolumn{6}{|l|}{ Dados especificos do meio } \\
\hline Porosidade efetiva & - & \multicolumn{4}{|c|}{0,18} \\
\hline Condutividade hidraulica & $m / a n o$ & \multicolumn{3}{|c|}{16,7} & 9,8 \\
\hline Gradiente hidrálico & - & \multicolumn{3}{|c|}{0,046} & 0,040 \\
\hline Dispersividade longitudinal & $m$ & 1,5 & 2,6 & 1,1 & 1,1 \\
\hline Dispersividade transversal & $m$ & 0,50 & 0,86 & 0,36 & 0,36 \\
\hline Dispersividade vertical & $m$ & 0,075 & 0,130 & 0,055 & 0,055 \\
\hline Densidade (solo seco) & $\mathrm{g} / \mathrm{cm}^{3}$ & \multicolumn{4}{|c|}{1,8} \\
\hline Fração de Carbono Orgânico & - & \multicolumn{4}{|c|}{0,01} \\
\hline Espessura do Aquiffero & $m$ & \multicolumn{4}{|c|}{10} \\
\hline \multicolumn{6}{|l|}{ Geometria do Receptor } \\
\hline Eixo $x$ & $m$ & 14,5 & 25,5 & 16 & 13,5 \\
\hline Eixoy & $m$ & 0 & 0 & 0 & 0 \\
\hline Eixo z - topo & $m$ & 0 & 0 & 0 & 0 \\
\hline Eixo $z$ - base & $m$ & 1,6 & 1 & 1 & 1,2 \\
\hline \multicolumn{6}{|l|}{ Geometria da fonte } \\
\hline Comprimento (eixo $x$ ) & $m$ & 8,5 & 8,5 & 10 & 11,9 \\
\hline Largura (eixo y) & $m$ & 6,5 & 6,5 & 7 & 8,1 \\
\hline Espessura (eixo z) & $m$ & 1,6 & 1,6 & 1,6 & 1,2 \\
\hline \multicolumn{6}{|l|}{ Massa de Contaminante } \\
\hline Chumbo & $\mathrm{kg}$ & 0,760 & 0,760 & 0,131 & 1,250 \\
\hline
\end{tabular}

Os resultados completos de algumas simulações encontram-se no Anexo 03.

\subsubsection{Simulações de transporte}

As concentrações determinadas em campo indicam duas plumas de contaminação por chumbo, em torno dos PMs 07 e 18, com concentrações detectadas no último monitoramento (fevereiro de 2001) de 15,4 e 6,59 mg/L, respectivamente. Como visto anteriormente, a partir destes poços foram realizadas calibragens para estimativa de massa de contaminante nas fontes originais, que embora estimadas não estão apresentadas nos mapas de isoconcentração de 
chumbo em água subterrânea, no qual configuram duas plumas com foco principal de contaminação a partir destes poços.

As simulações foram efetuadas para as distâncias de $235 \mathrm{~m}$ da Fonte A para o rio Cotia, $135 \mathrm{~m}$ da Fonte A para o PM-07, $70 \mathrm{~m}$ da Fonte A para um hipotético poço receptor em uso futuro, $90 \mathrm{~m}$ da Fonte $B$ para outro hipotético poço receptor em uso futuro e de $111 \mathrm{~m}$ da Fonte $B$ para o rio, sendo estas distâncias minimas aproximadas até cada ponto receptor definido.

O rio Cotia foi definido como receptor atual, caracterizando a necessidade de simulações de transporte de contaminante para o rio a partir das fontes $A$ e $B$. $A$ simulação da Fonte A para o PM-07 pretendeu verificar a possibilidade de haver aporte de contaminante neste poço a partir desta fonte. Este aporte pode ser significativo se somado ao contaminante proveniente da Fonte $B$. Cabe ressaltar que o modelo AT123D não permite a sobreposição de plumas, no caso da haver aporte significativo de contaminante para o PM-07 a partir da fonte $A$.

As simulações em relação a hipotéticos poços de captação em uso futuro da área, devem-se ao critério adotado pela CETESB de preservação da água subterrânea, independentemente do uso atual, justificando uma avaliação de risco para um cenário futuro, auxiliando numa previsão para esta possibilidade de uso.

As fontes de contaminação foram consideradas instantâneas, uma vez que há alguns anos não há disposição dos efluentes industriais que deram origem à contaminação por chumbo no local, de acordo com o histórico apresentado e não se considerou recarga de contaminante a partir da zona não saturada.

A partir dos levantamentos de campo foi possivel definir uma condutividade hidráulica de 16,7 m/ano e gradiente hidráulico de 4,6 \% no trecho entre a Fonte $A$ e - PM-07, condutividade hidráulica de 13,6 m/ano e gradiente hidráulico de 4,3\% da Fonte A para o rio e condutividade hidráulica de $9,8 \mathrm{~m} / a n o$ e gradiente hidráulico de $4 \%$ no trecho entre a Fonte $B$ e o rio Cotia. Apesar da ocorrência de gradientes hidráulicos na área de até 10 \% localmente, foram considerados nas simulações de transporte os gradientes acima, que correspondem àqueles mais significativos para os trechos envolvidos nas simulações.

De acordo com pesquisa bibliográfica, adotou-se uma porosidade efetiva de fluxo de 18\% (Fetter, 1988 e 1994), valor médio característico para solo síltico 
argilo-arenoso.

Um aspecto importante a ser ressaltado diz respeito à geometria do receptor. O modelo admite como receptor, um poço com o eixo $x$ sendo a distância longitudinal da fonte para o poço, no eixo y foram considerados valores nulos e topo e base do eixo z, o NA e base do filtro, caso do PM-07 que possui lâmina d'água de 1,2 m na simulação. Para o rio Cotia e poços de uso futuro, admitiu-se como $2 \mathrm{~m}$ o intervalo de captação de água subterrânea.

Tabela 23 - Parâmetros utilizados para Modelagem de Transporte.

\begin{tabular}{|c|c|c|c|c|c|c|}
\hline \multicolumn{7}{|c|}{ Dados para Modelagem de Transporte } \\
\hline Parâmetros & Unidade & $\begin{array}{l}\text { Fonte A } \\
\text { - PM-07 }\end{array}$ & $\begin{array}{c}\text { Fonte A } \\
-R e c \\
70 \mathrm{~m}\end{array}$ & $\begin{array}{c}\text { Fonte A } \\
- \text { rio } \\
\text { Cotia }\end{array}$ & $\begin{array}{c}\text { Fonte } B \\
\text { - rio } \\
\text { Cotia }\end{array}$ & $\begin{array}{c}\text { Fonte } B \\
-R e c \\
90 \mathrm{~m}\end{array}$ \\
\hline \multicolumn{7}{|l|}{ Controle } \\
\hline Aqüifero infinito (eixo y) & $m$ & \multicolumn{5}{|c|}{ Sim } \\
\hline Infinito (eixo z) & $m$ & \multicolumn{5}{|c|}{ Não } \\
\hline Tipo de Fonte & - & \multicolumn{5}{|c|}{ Instantânea } \\
\hline Tempo de Simulação & anos & \multicolumn{5}{|c|}{100 anos } \\
\hline \multicolumn{7}{|l|}{$\begin{array}{c}\text { Dados específicos do } \\
\text { meio }\end{array}$} \\
\hline Porosidade efetiva & - & \multicolumn{5}{|c|}{0,18} \\
\hline Condutividade hidráulica & m/ano & 16,7 & 16,7 & 13,6 & 9,8 & 9,8 \\
\hline Gradiente hidráulico & - & 0,046 & 0,046 & 0,043 & 0,04 & 0,04 \\
\hline Dispersividade longitudinal & $m$ & 13,5 & 7,0 & 23,5 & 11,1 & 9,0 \\
\hline Dispersividade transversal & $m$ & 4,50 & 2,33 & 7,80 & 3,70 & 3,00 \\
\hline Dispersividade vertical & $m$ & 0,67 & 0,35 & 1,20 & 0,55 & 0,45 \\
\hline Densidade (solo seco) & $\mathrm{g} / \mathrm{cm}^{3}$ & \multicolumn{5}{|c|}{1,8} \\
\hline $\begin{array}{c}\text { Fração de Carbono } \\
\text { Orgânico }\end{array}$ & - & \multicolumn{5}{|c|}{0,01} \\
\hline Espessura do Aqülfero & $m$ & \multicolumn{5}{|c|}{10} \\
\hline \multicolumn{7}{|l|}{ Geometria do Receptor } \\
\hline Eixo $x$ & $m$ & 139 & 74 & 239 & 117 & 96 \\
\hline Eixo $y$ & $m$ & 0 & 0 & 0 & 0 & 0 \\
\hline Eixo z - topo & $m$ & 0 & 0 & 0 & 0 & 0 \\
\hline Eixo z - base & $m$ & 1,2 & 2,0 & 2,0 & 2,0 & 2,0 \\
\hline \multicolumn{7}{|l|}{ Geometria da fonte } \\
\hline Comprimento (eixo $x$ ) & $m$ & \multicolumn{3}{|c|}{8,5} & \multicolumn{2}{|c|}{11,9} \\
\hline Largura (eixo y) & $m$ & \multicolumn{3}{|c|}{6,5} & \multicolumn{2}{|c|}{8,1} \\
\hline Espessura (eixo z) & $m$ & \multicolumn{3}{|c|}{1,6} & \multicolumn{2}{|c|}{1,2} \\
\hline \multicolumn{7}{|l|}{ Massa de Contaminante } \\
\hline Chumbo & $\mathrm{kg}$ & \multicolumn{3}{|c|}{0,76} & \multicolumn{2}{|c|}{1,25} \\
\hline
\end{tabular}


A partir da aplicação do modelo, foram obtidos os resultados apresentados nos gráficos abaixo. Os resultados completos de algumas das simulações efetuadas, onde estão apresentadas as concentrações médias anuais, encontramse no Anexo 03. Incluíram-se somente algumas simulações, a título de exemplo do tipo de saída dos dados do modelo, visto que a apresentação de todas as simulações geraria um número da páginas inviável para o anexo.

De acordo com os resultados apresentados nos gráficos da figura 17, verificase que em todas as situações o contaminante atinge o receptor, entretanto, os padrões de referência são distintos, dependentes do tipo de receptor. Para o rio como receptor, deve-se considerar o padrão estabelecido pela Resolução CONAMA $n^{\circ}$ 20/86 para rios classe 3, de 0,05 $\mathrm{mg} / \mathrm{h}$, enquanto que para os poços como receptores, deve-se considerar a Portaria 1469, de 0,01 mg/L.

Para o transporte da Fonte A para um poço receptor a $70 \mathrm{~m}$, observa-se que o aporte de chumbo em água subterrânea inicia-se a partir do terceiro ano em niveis muito baixos, mas em rápido crescimento até o ano 13, quando atinge o pico de concentração em 0,162 $\mathrm{mg} / \mathrm{L}$, para então decrescer acentuadamente até os anos $35 / 40$ e manter-se em níveis muito baixos até o final da simulação em 100 anos. Ao se considerar o valor máximo permitido pela Portaria 1469 (0,01 mg/L), observa-se que a partir do ano 6 este limite é superado, mantendo-se acima dele até o ano 37.

Para o transporte a partir da Fonte A para o PM-07, observa-se que o aporte de chumbo inicia-se a partir do quinto ano em niveis muito baixos, mas em constante crescimento até os anos 26, 27 e 28, quando atinge o pico de concentração em $0,035 \mathrm{mg} / \mathrm{L}$, para então decrescer constantemente até o final da simulação em 100 anos. Esta concentração máxima citada representa o maior aporte de chumbo para o PM-07, valor da ordem de 0,2 \% da concentração de 15,4 $m g / L$ detectada no poço receptor. 

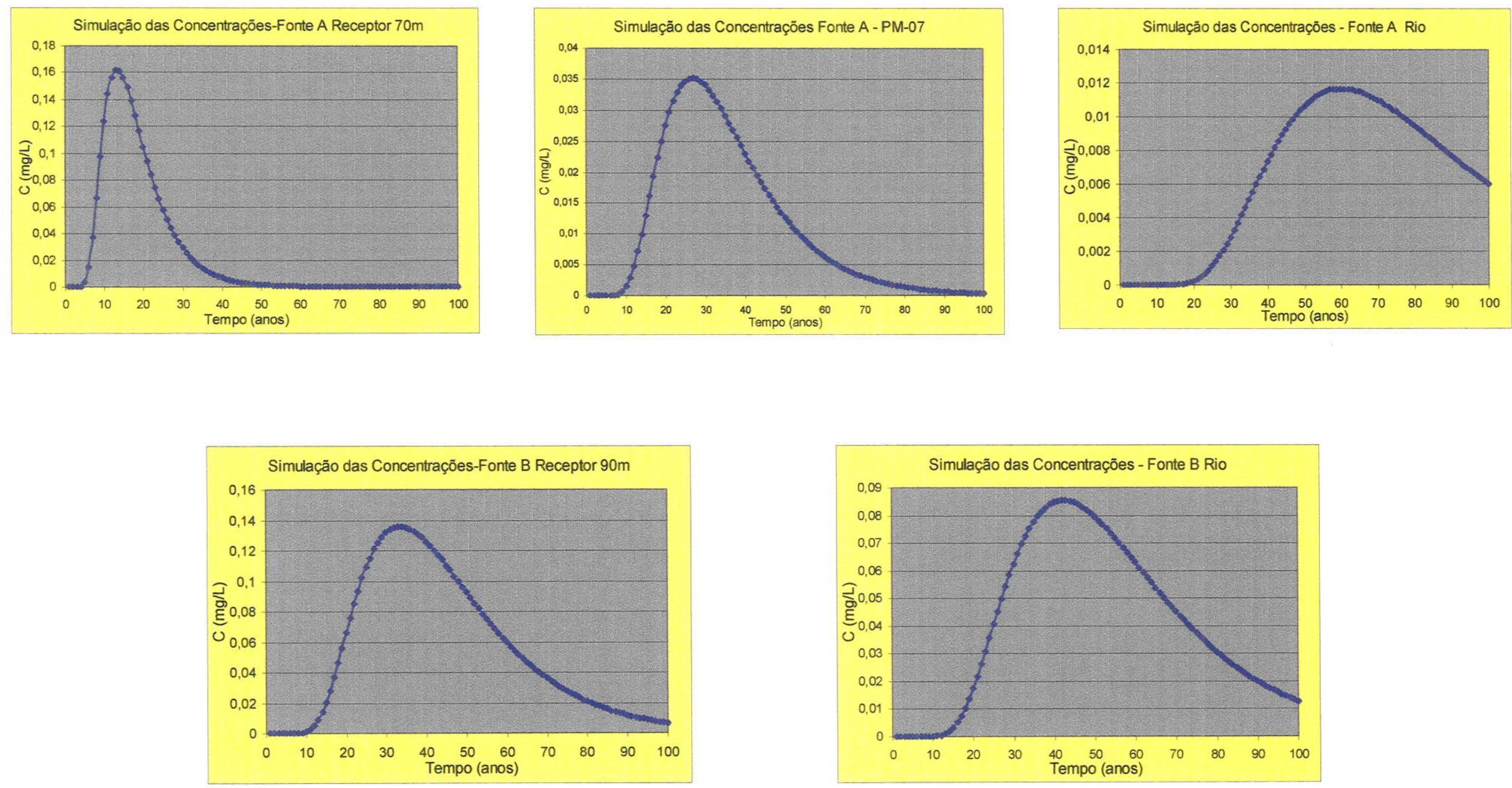

Figura 17 - Curvas de distribuição das concentrações de chumbo nos receptores simulados, a partir das Fontes A e B. 
Na simulação considerando o rio Cotia como receptor em relação à mesma Fonte $A$, o contaminante só atinge o ro a partir do décimo ano em níveis extremamente baixos, iniciando curva ascendente de concentração significativa a partir do vigésimo ano até o ano 57, quando estabiliza-se até o ano $63 \mathrm{em}$ concentração de $0,012 \mathrm{mg} / \mathrm{L}$, iniciando trecho de curva descendente de concentração no rio até o final da simulação. Ao se considerar o valor máximo permitido pela Resolução CONAMA $n^{\circ}$ 20/86 (0,05 mg/L), observa-se que este limite não é atingido em nenhum momento.

Para o transporte da Fonte B para um poço receptor a $90 \mathrm{~m}$, observa-se que o aporte de chumbo em água subterrânea inicia-se a partir do sexto ano em niveis muito baixos, mas em forte curva ascendente até os anos 33 e 34, quando atinge o pico de concentração em $0,136 \mathrm{mg} / \mathrm{L}$, para então decrescer até o final da simulação em 100 anos. Ao se considerar o valor máximo permitido pela Portaria 1469 (0,01 $\mathrm{mg} / \mathrm{L}$ ), observa-se que a partir do ano 14 este limite é superado, mantendo-se acima dele até o ano 92.

Para a simulação a partir da Fonte B com o rio Cotia como receptor, observase que o chumbo atinge o rio a partir do sétimo ano, em concentrações extremamente baixas, iniciando um aumento no aporte até os anos 41 a 44 quando atinge a máxima concentração de chegada com $0,085 \mathrm{mg} / \mathrm{L}$, decrescendo continuamente até o final da simulação. Pode-se observar que o limite imposto pela Resolução CONAMA n $n^{\circ} 20 / 86(0,05 \mathrm{mg} / \mathrm{L})$ é superado no periodo entre os anos 27 e 67 .

\subsubsection{Estimativa do Risco em Solo}

De acordo com a avaliação efetuada no item 6.2 e dados de entrada para simulação através do modelo, efetuaram-se as estimativas de risco, para as rotas de ingestão de solo e contato dermal com solo, conforme tabela a seguir. 
Tabela 24 - Resultados das Simulações de Risco efetuadas.

\begin{tabular}{|c|c|c|c|c|c|}
\hline \multicolumn{2}{|c|}{ Rotas de Exposiçáo } & $\begin{array}{c}I D \\
(\mathrm{mg} / \mathrm{kg}-\text { dia })\end{array}$ & $\begin{array}{c}I D C \\
(m g / k g \cdot d i a)\end{array}$ & $\begin{array}{c}\text { IDM } \\
\text { (mg/kg-dia) }\end{array}$ & QR \\
\hline \multirow{2}{*}{$\begin{array}{l}\text { Contato Dermal com } \\
\text { Solo (Conservador) }\end{array}$} & Adulto & $.128 E-03$ & $122 E-03$ & $.172 E-04$ & $.340 E-01$ \\
\hline & Criança & $294 E-03$ & $.282 E-03$ & $.265 E-04$ & $.784 E-01$ \\
\hline \multirow{2}{*}{$\begin{array}{l}\text { Ingestão de Solo } \\
\text { (Conservador) }\end{array}$} & Adulto & $.682 E-03$ & $654 E-03$ & $.919 E-04$ & $.182 E+00$ \\
\hline & Criança & $.545 E-02$ & $.523 E-02$ & $.490 E-03$ & $.145 E+01$ \\
\hline \multirow{2}{*}{$\begin{array}{l}\text { Contato Dermal com } \\
\text { Solo (Usual) }\end{array}$} & Adulto & $.128 E-03$ & $.350 E-05$ & $.492 E-06$ & $.971 E-03$ \\
\hline & Criança & $.294 E-03$ & $.807 E-05$ & $.756 E-06$ & $.224 E-02$ \\
\hline \multirow{2}{*}{$\begin{array}{c}\text { Ingestão de Solo } \\
\text { (Usual) }\end{array}$} & Adulto & $.682 E-03$ & $.187 E-04$ & $263 E-05$ & $.519 E-02$ \\
\hline & Criança & $.545 E-02$ & $.149 E-03$ & $140 E-04$ & $.415 E-01$ \\
\hline
\end{tabular}

Legenda: $I D=$ Ingresso Diário; $I D C=$ Ingresso Diário Crónico; $I D M=$ Ingresso Diário Médio; $Q R=$ Quociente de Risco

Segundo os resultados acima, há riscos de efeitos não cancerígenos na rota de ingestão de solo para crianças em cenário consenvador. Estes resultados referem-se aos valores adotados como de referência (default) para as rotas, valores extremamente consenvadores para a situação do local. Entretanto, ao se considerar os valores mais compativeis com a realidade do local (usual), os resultados não apresentam riscos acima dos admitidos pela CETESB.

Os valores conservadores consideram situações de exposição freqüentes e duradouras, ou seja, quase diariamente e por algumas horas durante o dia. O local do solo contaminado é uma via de passagem de moradores e trabalhadores da região, as quais raramente permanecem no local o suficiente para a exposição simulada. A adoção de um valor para o local com menor tempo de exposição ao solo, ainda conservador em relação ao quadro real, resultou em índices permissiveis para exposição.

Pelo exposto acima, conclui-se preliminarmente pela inexistência de risco para o cenário mais provável de exposição ao solo contaminado.

\subsubsection{Estimativa do Risco em Água}

Para os cálculos de risco considerando-se a água como rota de exposição, elaboraram-se simulações de risco para períodos e épocas diferentes, de acordo com os resultados obtidos nas concentrações de chegada do contaminante em cada 
receptor considerado. Assim, elaboraram-se cálculos para os periodos integrais da simulação, ou seja, 100 anos e para intervalos de tempo menores, cujas concentrações médias eram significativas para cada periodo especificamente.

Estas estimativas de risco foram realizadas para dois poços de captação de água subterrânea em hipotético uso futuro, para consumo nobre em ambiente residencial, locados estes poços em pontos não contaminados por chumbo atualmente, desconsiderando retardamento do contaminante no transporte $e$ quaisquer efeitos que os bombeamentos de água a partir destes dois poços possam causar no regime de fluxo subterrâneo caracterizado para as simulações.

Da observação dos gráficos de simulação de transporte para estes dois poços, adotam-se critérios distintos para a definição dos períodos para estimativa de risco. Para o poço receptor a $70 \mathrm{~m}$ da fonte $A$, a simulação mostra que a partir do ano 38 até o final do período simulado, ocorreriam concentrações abaixo do padrão de potabilidade da Portaria 1469. Assim, adotaram-se dois intervalos para estimativa de riscos, um primeiro periodo com os quarenta anos iniciais, que incluem todo o intervalo com concentrações acima do limite. Para este cálculo deve-se executar o modelo com os dados de transporte para 40 anos e entrar com os dados de exposição e toxicidade para o cálculo de risco. Para um segundo periodo, entre os anos 38 e 100, calculou-se a concentração média ao longo do período no receptor e alimentou o modelo como dado de concentração específica para executar o programa.

Em relação ao poço receptor a $90 \mathrm{~m}$ da fonte $B$, adotou-se um critério de estimativa de risco para o periodo integral da simulação, visto que em quase oitenta anos deste periodo, as concentrações estimadas estão acima do limite regulamentado.

As simulações de transporte realizadas não consideraram adsorção do chumbo ao solo na zona saturada. O modelo considera que o soluto passa por um poço e depois de um periodo para cada poço, conforme distância da fonte, não há mais concentração de chumbo no ponto. Por exemplo, para o PM-18 este período seria de 33 anos, momento a partir do qual pela simulação todo o chumbo em água teria passado pelo poço. Entretanto, deve haver adsorção de chumbo ao solo e somente o monitoramento fornecerá dados para sua estimativa. Por isso, as 
estimativas de risco para pontos de exposição que não apresentam concentração de chumbo atualmente.

Tabela 25 - Resultados das Simulações de Risco efetuadas com transporte a partir da Fonte $A$.

\begin{tabular}{|c|c|c|c|c|c|c|}
\hline \multicolumn{3}{|c|}{$\begin{array}{l}\text { Rotas de Exposição a Água } \\
\text { Fonte A - Receptor } 70 \mathrm{~m}\end{array}$} & \multirow{2}{*}{\begin{tabular}{|c|}
$\begin{array}{c}\text { ID } \\
(\mathrm{mg} / \mathrm{kg} \cdot \mathrm{dla})\end{array}$ \\
$.238 \mathrm{E}-04$ \\
\end{tabular}} & \multirow{2}{*}{\begin{tabular}{|c|c|c|c|}
$\begin{array}{c}\mathrm{IDC} \\
(\mathrm{mg} / \mathrm{kg} \cdot \text { dia })\end{array}$ \\
$228 \mathrm{E}-04$ \\
\end{tabular}} & \multirow{2}{*}{$\frac{\begin{array}{c}\mathrm{IDM} \\
(\mathrm{mg} / \mathrm{kg} \text {-dia })\end{array}}{.321 \mathrm{E}-05}$} & \multirow{2}{*}{$\begin{array}{c}Q R \\
.634 E-02 \\
\end{array}$} \\
\hline Ingestão & Ano 38 a ano & Adulto & & & & \\
\hline ingestan & 100 & Criança & $.680 E-04$ & $.652 E-04$ & $.611 E-05$ & $.181 E-01$ \\
\hline \multirow{2}{*}{$\begin{array}{l}\text { Contato } \\
\text { Dermal } \\
\end{array}$} & \multirow{2}{*}{$\begin{array}{c}\text { Ano } 38 \text { a ano } \\
100 \text { (usual) }\end{array}$} & Adulto & $.135 E-09$ & $.130 E-09$ & $.183 E-10$ & $.361 E-07$ \\
\hline & & Criança & $.310 E-09$ & $.297 E-09$ & $.279 E-10$ & $.826 E-07$ \\
\hline \multirow{2}{*}{ Ingestão } & \multirow{2}{*}{$\begin{array}{l}\text { Ano } 38 \text { a ano } \\
100 \text { (conserv) }\end{array}$} & Adulto & $.340 E-04$ & $.340 E-04$ & $.159 E-04$ & $.944 E-02$ \\
\hline & & Criança & $.102 E-03$ & 102E-03 & $.956 E-05$ & $.283 E-01$ \\
\hline \multirow{2}{*}{$\begin{array}{l}\text { Contato } \\
\text { Dermal }\end{array}$} & \multirow{2}{*}{$\begin{array}{l}\text { Ano } 38 \text { a ano } \\
100 \text { (conserv) }\end{array}$} & Adulto & $.376 E-09$ & $.376 E-09$ & $.176 E-09$ & $.104 E-06$ \\
\hline & & Criança & $.860 E-09$ & $.860 E-09$ & $.807 E-10$ & $.239 E-06$ \\
\hline \multirow{2}{*}{ Ingestão } & \multirow{2}{*}{$\begin{array}{c}\text { Ano } 1 \text { ao ano } \\
40 \text { (usual) }\end{array}$} & Adulto & $.270 E-02$ & $.270 E-02$ & $.127 E-02$ & $.750 E+00$ \\
\hline & & Criança & $.105 E-01$ & $.100 \mathrm{E}-01$ & $.940 E-03$ & $.279 E+01$ \\
\hline \multirow{2}{*}{$\begin{array}{l}\text { Contato } \\
\text { Dermal }\end{array}$} & \multirow{2}{*}{$\begin{array}{c}\text { Ano } 1 \text { ao ano } \\
40 \text { (usual) }\end{array}$} & Adulto & $.208 E-07$ & $.200 E-07$ & $.281 E-08$ & $.555 E-05$ \\
\hline & & Criança & $.477 E-07$ & $.457 E-07$ & $.429 E-08$ & $.127 E-04$ \\
\hline \multirow{2}{*}{ Ingestão } & \multirow{2}{*}{$\begin{array}{l}\text { Ano } 1 \text { ao ano } \\
40 \text { (conserv) }\end{array}$} & Adulto & $.366 E-02$ & $.351 E-02$ & $.494 E-03$ & $.975 E+00$ \\
\hline & & Criança & $.157 E-01$ & $.157 E-01$ & $.147 E-02$ & $.436 E+01$ \\
\hline \multirow{2}{*}{$\begin{array}{l}\text { Contato } \\
\text { Dermal }\end{array}$} & \multirow{2}{*}{$\begin{array}{l}\text { Ano } 1 \text { ao ano } \\
40 \text { (consen) }\end{array}$} & Adulto & $.298 E-07$ & $.298 E-07$ & $.140 \mathrm{E}-07$ & $.829 E-05$ \\
\hline & & Criança & $.132 E-06$ & $.132 E \sim 06$ & $.124 E-07$ & $.368 E-04$ \\
\hline
\end{tabular}

Legenda: $I D=$ Ingresso Diário; $I D C=$ Ingresso Diário Crônico; $I D M=$ Ingresso Diário Médio; $Q R=$ Quociente de Risco

Para as estimativas de risco considerando-se o periodo entre os anos $38 \mathrm{e}$ 100 , não há riscos caracterizados acima do índice admitido para $Q R$, sendo o maior risco para efeito não cancerigeno de 0,0283 para crianças em cenário conservador e rota de ingestão de água.

Em relação ao período que envolve os primeiros quarenta anos, os ríscos foram caracterizados somente para a rota de ingestão de água contaminada. Para os efeitos não cancerígenos $(Q R)$ há riscos para as crianças, tanto em cenário conservador quanto em usual, com destaque para o cenário de parâmetros de exposição mais acentuada que apresentou o maior quociente de risco, de 4,36.

Dos resultados, um aspecto que deve ser salientado diz respeito à existência de risco para o cenário usual de exposição, a partir de dados próximos de um 
cenário real provável de uso futuro no local.

Pelo exposto, conclui-se preliminarmente pela existência de risco para o cenário mais provável de exposição para o período até 40 anos. A ausência de riscos após este período, deve ser monitorada, para avaliação de adsorção de chumbo ao solo na zona saturada e de outros condicionantes de potabilidade para água subterrânea. Porém, o conservadorismo das premissas torna esta hipótese plausivel.

Abaixo, apresentam-se os resultados de risco a partir da Fonte $B$.

Tabela 26 - Resultados das Simulações de Risco efetuadas com transporte a partir da Fonte $B$.

\begin{tabular}{|c|c|c|c|c|c|c|}
\hline \multicolumn{3}{|c|}{$\begin{array}{l}\text { Rotas de Exposição a Água } \\
\text { Fonte B - Receptor } 90 \mathrm{~m}\end{array}$} & \multirow{2}{*}{$\frac{\begin{array}{c}1 D \\
(\mathrm{mg} / \mathrm{kg}-\mathrm{dia})\end{array}}{.316 \mathrm{E}-02}$} & \multirow{2}{*}{$\begin{array}{c}1 D C \\
(\mathrm{mg} / \mathrm{kg} \text {-clia) } \\
303 E-02 \\
\end{array}$} & \multirow{2}{*}{$\begin{array}{c}\begin{array}{c}\text { IDM } \\
(\mathrm{mg} / \mathrm{kg}-\mathrm{c} / \mathrm{a})\end{array} \\
.426 \mathrm{E}-03\end{array}$} & \multirow{2}{*}{$\frac{\text { QR }}{842 E+00}$} \\
\hline & & Adulto & & & & \\
\hline Ingestao & & Criança & $.903 E-02$ & $.866 E-02$ & $.812 E-03$ & $.241 E+01$ \\
\hline \multirow{2}{*}{$\begin{array}{l}\text { Contato } \\
\text { Dermal }\end{array}$} & \multirow{2}{*}{$\begin{array}{l}100 \text { anos } \\
\text { (usual) }\end{array}$} & Adulto & $.180 E-07$ & $.173 E-07$ & $.243 E-08$ & $.479 E-05$ \\
\hline & & Criança & $.412 E-07$ & $.395 E-07$ & $.370 E-08$ & $.110 E-04$ \\
\hline \multirow{2}{*}{ Ingeståo } & \multirow{2}{*}{$\begin{array}{c}100 \text { anos } \\
\text { (conservador) }\end{array}$} & Adulto & $.390 E-02$ & $.390 E-02$ & $.183 E-02$ & $108 E+01$ \\
\hline & & Criança & $.136 E-01$ & $.136 E-01$ & $.127 E-02$ & $376 E+01$ \\
\hline \multirow{2}{*}{$\begin{array}{l}\text { Contato } \\
\text { Dermal }\end{array}$} & \multirow{2}{*}{$\begin{array}{c}100 \text { anos } \\
\text { (conservador) }\end{array}$} & Adulto & $.432 E-07$ & $.432 E-07$ & $.202 E-07$ & $.120 E-04$ \\
\hline & & Criança & $.114 E-06$ & $.114 E-06$ & $.107 E-07$ & $.318 E-04$ \\
\hline
\end{tabular}

Legenda: $I D=$ Ingresso Diário; $I D C=$ Ingresso Diário Crônico; $I D M=$ Ingresso Diário Médio; $Q R=$ Quociente de Risco

Os resultados da tabela acima mostram a existência de riscos somente para ingestão de água contaminada, tanto para os parâmetros conservadores como para os usuais, caracterizarando-se riscos de efeitos não cancerígenos para adultos e crianças, sendo mais intensos para as crianças.

Neste quadro, exceção é feita para os efeitos não cancerígenos em adultos com parâmetros usuais, os quais apresentaram resultado menor que um, não indicando risco. Por outro lado, os riscos mais acentuados são para as crianças, a partir de parâmetros conservadores. Novamente deve-se salientar a existência de risco para o cenário usual de exposição.

Pelo exposto acima, conclui-se preliminarmente pela existência de risco para o cenário mais provável de exposição para o período simulado, o que era esperado, 
uma vez que o limite de potabilidade para o contaminante é de 0,01 $\mathrm{mg} / \mathrm{L}$, ou seja, mais de 1500 vezes abaixo da concentração maior considerada na simulação, ressaltando-se que limite de potabilidade não significa limite de risco.

Os resultados obtidos nos cálculos de risco são baseados em fatores que podem gerar incertezas na avaliação de risco, como massa e retardamento de contaminante e ausência de dados toxicológicos, que devem ser atualizados de acordo com a disponibilidade de dados especificos.

De acordo com os riscos estimados para os receptores, referentes a cada fonte e rota de exposição (Tabelas $25 \mathrm{e26}$ ), podem-se estimar os SSTL para cada receptor em sua rota de exposição que ofereça risco, conforme tabela abaixo.

Tabela 27 - Valores de SSTL estimados

\begin{tabular}{|c|c|c|c|c|}
\hline \multicolumn{3}{|c|}{$\begin{array}{c}\text { Rotas de Exposiçáo a Agua } \\
\text { Fonte A - Receptor } 70 \mathrm{~m}\end{array}$} & $Q R$ & SSTL [mg/L] \\
\hline \multirow{2}{*}{ Ingestão } & $\begin{array}{c}\text { Ano } 1 \text { ao ano } 40 \\
\text { (usual) }\end{array}$ & \multirow{2}{*}{ Criança } & \multirow{2}{*}{1} & 0,058 \\
\hline & $\begin{array}{l}\text { Ano } 1 \text { ao ano } 40 \\
\text { (conservador) }\end{array}$ & & & 0,037 \\
\hline \multicolumn{3}{|c|}{$\begin{array}{c}\text { Rotas de Exposição a Água } \\
\text { Fonte B - Receptor } 90 \mathrm{~m}\end{array}$} & $Q R$ & SSTL [mg/L] \\
\hline \multirow{3}{*}{ Ingestão } & $\begin{array}{c}100 \text { anos } \\
\text { (usual) }\end{array}$ & \multirow{2}{*}{ Criança } & \multirow{3}{*}{1} & 0,056 \\
\hline & $\begin{array}{c}100 \text { anos } \\
\text { (conservador) }\end{array}$ & & & 0,036 \\
\hline & $\begin{array}{c}100 \text { anos } \\
\text { (conservador) }\end{array}$ & Adulto & & 0,125 \\
\hline
\end{tabular}

Legenda: $Q R=$ Quociente de Risco; SSTL = Valor Alvo Especifico para o Local

Pode-se observar que todos os valores de SSTL são superiores ao VMP da Portaria 1469, para os cenários propostos nas estimativas de risco. Estes valores representam as máximas concentrações nos pontos de exposição sem que haja riscos de efeitos não cancerigenos para cada receptor. O SSTL em cada ponto de exposição deve ser o valor mais restritivo.

Os gráficos referentes a estas simulações (Figuras 17 e 20), permitem observar que estes valores são superados entre os anos 07 e $28(0,037 \mathrm{mg} / \mathrm{L})$ considerando-se a Fonte $A$ com receptor a $70 \mathrm{~m}$ e entre os anos 17 e $69(0,036$ $m g / L)$ a partir da Fonte $B$ com receptor a $90 \mathrm{~m}$. 


\section{CONCLUSÕES}

$>$ O vazamento de ácido clorídrico gerou uma pluma de contaminação de cloreto em água subterrânea, em configuração condicionada pelo fluxo subterrâneo e infiltração a partir do escoamento superficial ocorrido. Os resultados também indicaram altas concentrações de cloreto em solo, porém, não há limites regulamentados para cloreto em solo;

$>$ A diminuição do $\mathrm{pH}$ pelo vazamento de ácido clorídrico proporcionou a migração dos metais da zona não saturada para a zona saturada e também gerou ambiente de mobilidade para os metais na zona saturada;

DEm solo, entre os metais, foi detectada contaminação somente por chumbo, com concentração acima do valor de intervenção para áreas residenciais proposto pela CETESB;

> Foi caracterizada a contaminação da água subterrânea local devido à presença de altas concentrações de chumbo e zinco, principalmente nos PMs 07 e 18. A pluma referente ao PM-18 deve-se à contaminação provocada pela Empresa, enquanto a pluma referente ao PM-07 deve-se à desativada fábrica de vulcanização de borracha;

$>A$ concentração de zinco acima do limite no PM-14, pode ser um indicativo de uma fonte $B$ mais extensa ou mesmo a presença de mais de uma fonte. Tal fato impõe a necessidade de avaliação especifica da área da empresa desativada de vulcanização e com monitoramentos posteriores. Isto pode impedir ou limitar o tipo de uso para poço de captação futura no local;

> A avaliação de risco para a rota de ingestão e contato dermal com solo contaminado e contato dermal com água contaminada concluiu pela inexistência de riscos. Entretanto, para a rota de ingestão de água contaminada concluiu pela existência de riscos para efeitos não cancerígenos, para adultos e crianças, com efeitos mais severos em crianças; 
Embora tenham-se adotado premissas consenvadoras para simulação de transporte e avaliação de risco, a metodologia adotada permite variações nestas premissas, que podem ser feitas à medida que se disponha de mais dados para adoção de modelos menos conservadores;

> Os Valores Alvo Especificos para o Local - SSTL para os pontos de exposição em água subterrânea estimados são mais permissivos do que o Valor Máximo Permitido (VMP) regulamentado pela Portaria 1469. 


\section{RECOMENDAÇÕES}

> A partir dos critérios adotados e do cenário exposto, recomenda-se como açãoresposta inicial o monitoramento trimestral dos poços de monitoramento existentes no local, para continuidade da avaliação da contaminação e verificação de efeitos de atenuação natural na migração das plumas;

$>$ Instalação de pelo menos mais um poço de monitoramento, à leste do PM-06, próximo à entrada da estrada Fernando Nobre, para melhor caracterização e controle da migração de pluma(s) para o rio Cotia;

$>$ Em função do risco para consumo de água subterrânea, deve-se manter atualizado um cadastro de explotação de água subterrânea, através do levantamento de dados permanente na área, a fim de se garantir que não ocorra consumo por esta rota, para quaisquer tipos de uso;

$>$ A empresa deve ter controle total no uso do poço de captação próximo da rua Torre Eiffel, a partir de análises físico-químicas periódicas, sem qualquer tipo de uso que não seja industrial;

$>$ Buscar formas legais de acesso à área interna da fábrica de vulcanização de borracha, para mapeamento do local, levantando dados hidrogeológicos, busca por possivel(is) fonte(s) de contaminação, poços de captação de água subterrânea, amostragem e análise de solo, instalação de poço(s) para amostragem e análises de água;

$>$ Realização de nova avaliação de risco para a área, assim que hajam novas e significativas informações sobre a área; 


\section{ANEXO 01}

Perfis Descritivos dos Poços de Monitoramento 


\begin{tabular}{|c|c|c|c|c|c|c|}
\hline \multicolumn{7}{|c|}{ DISSERTAÇÃO DE MESTRADO - EURÉLIO TOSO JR. } \\
\hline \multicolumn{7}{|c|}{ RODOVIA RAPOSO TAVARES Km 29} \\
\hline \multicolumn{3}{|c|}{ EQUIPAMENTO: TRADO MECÂNICO } & \multicolumn{2}{|c|}{ PERFURAÇÃO: 4" } & \multicolumn{2}{|c|}{ REVESTIMENTO: $2 "$} \\
\hline \multicolumn{2}{|c|}{ PM-06 } & \multicolumn{2}{|c|}{ PM-07 } & \multicolumn{3}{|c|}{ PM-08 } \\
\hline Início: 23/06/98 & Fim: 23/06/98 & Início: $11 / 02 /$ & Fim: 11/02/99 & & 11/02/99 & Fim: 11/02/99 \\
\hline Profun: $4,30 \mathrm{~m}$ & N.A. Estab: $3,72 \mathrm{~m}$ & Profun: 4,24 & N.A. Estab.: $3,00 \mathrm{~m}$ & & : $4,37 \mathrm{~m}$ & N.A. Estab.: $3,61 \mathrm{~m}$ \\
\hline
\end{tabular}

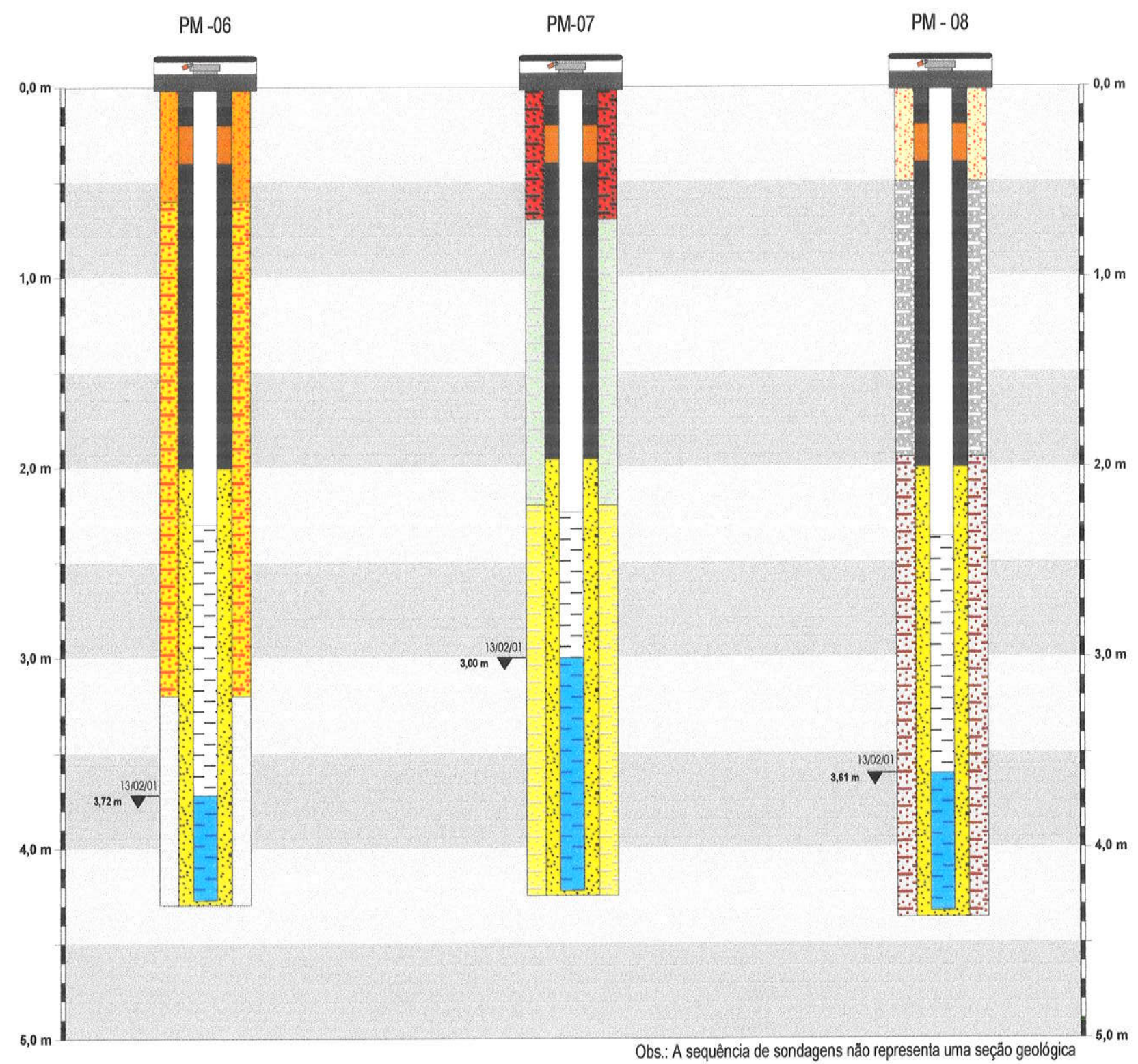

Legenda (Construtivo)

Solo reposto

$\therefore$ Pré-filtro de areia

Selo em bentonita

Selo sanitário em concreto
Legenda (Litologia)

Areia variada argilosa, vermelha escura, com pedregulhos pequenos. Aterro.

Areia argilosa, vermelha escura. Aterro.

Argila arenosa, vermelha, com pedregulhos. Aterro.

Argila silto-arenosa (areia fina e média), amarela e vermelha. S.A.R. (Solo de Alteração de Rocha)

Argila silto-arenosa (areia fina e média), cinza clara. S.A.R.
Argila silto-arenosa (areia variada), cinza escura, micácea. S.A.R.

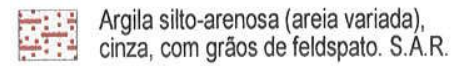

Argila silto-arenosa (areia fina e média) cinza, com fragmentos milimétricos de rocha, micácea. S.A.R.

Argila siltosa pouco arenosa (areia fina e média), amarela e cinza, micácea. S.A.R. 


\begin{tabular}{|c|c|c|c|c|c|c|}
\hline \multicolumn{7}{|c|}{ DISSERTAÇÃO DE MESTRADO - EURÉLIO TOSO JR. } \\
\hline \multicolumn{7}{|c|}{ RODOVIA RAPOSO TAVARES Km 29} \\
\hline \multicolumn{3}{|c|}{ EQUIPAMENTO: TRADO MECÂNICO } & \multicolumn{2}{|c|}{ PERFURAÇÃO: 4" } & \multicolumn{2}{|c|}{ REVESTIMENTO: $2 "$} \\
\hline \multicolumn{2}{|c|}{ PM-011 } & \multicolumn{3}{|c|}{ PM-13 } & \multicolumn{2}{|c|}{ PM-14 } \\
\hline Início: 20/04/99 & Fim: 26/04/99 & Início: 29/01/ & & Fim: 29/01/01 & Iń́cio: 29/01/01 & Fim: 29/01/01 \\
\hline Profun: $6,00 \mathrm{~m}$ & N.A. Estab: 4,92 m & Profun: 4,75 & & N.A. Estab.: 2,15 m & Profun: 4,56 m & N.A. Estab.: 2,61 m \\
\hline
\end{tabular}

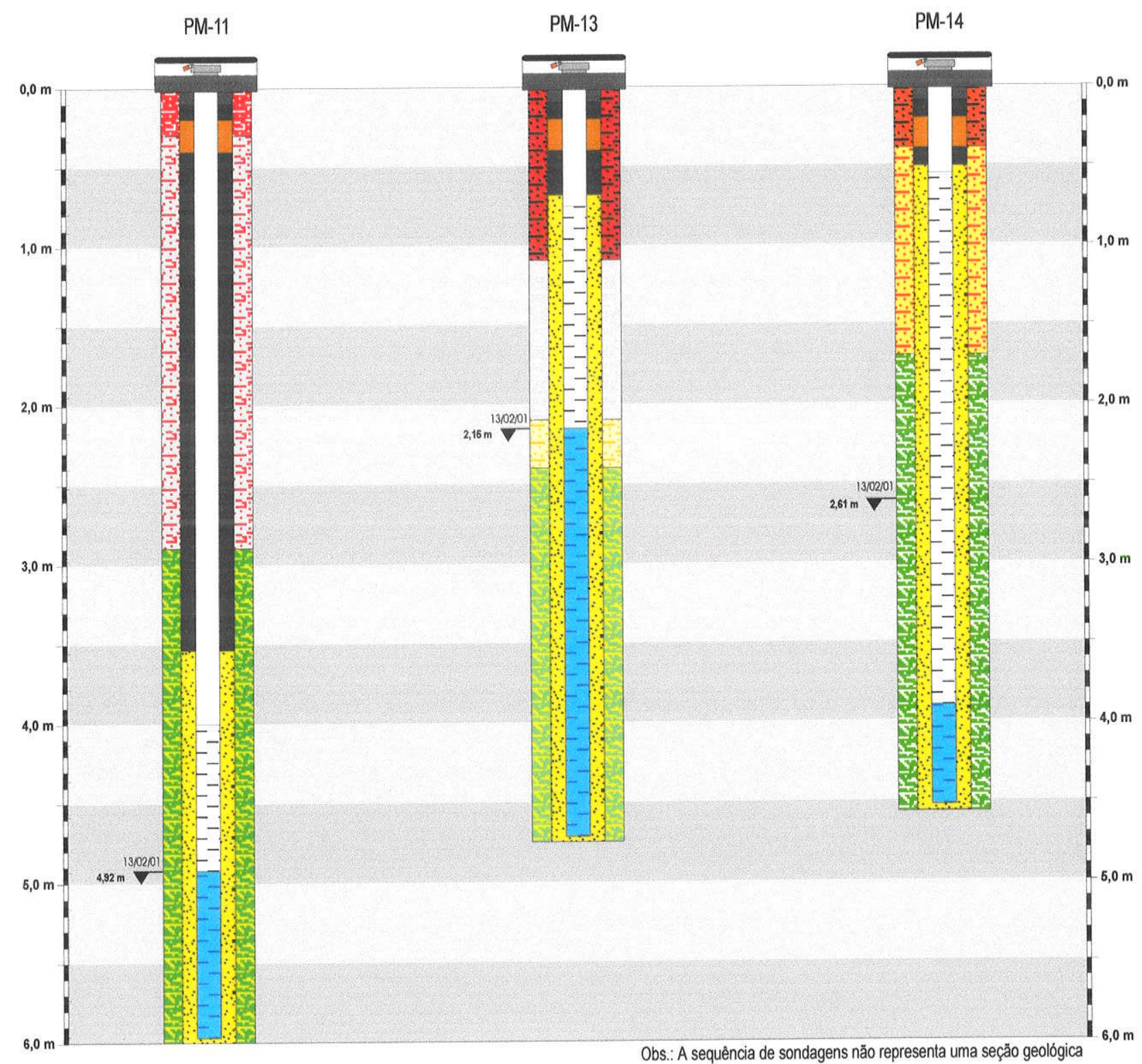

Legenda (Construtivo)

Solo reposto

Pré-filtro de areia

Selo em bentonita

Selo sanitário em concreto
Legenda (Litologia)

Solo argilo-arenoso com pedregulhos, vermelho pouco poroso - Aterro

Solo argilo-arenoso com pedregulhos pequenos, poroso com matéria orgânica - Aterro

Argila arenosa, vermelha, com pedregulhos pequenos. Aterro

Areia variada argilosa, amarela, micácea - S.A.R. (Solo de Alteraçäo de Rocha) pequenos, vermelha e amarela, micácea - S.A.R.
Argila arenosa (areia fina e média) com pedregulhos, cinza clara. Solo de alteraçäo de rocha. S.A.R.

Argila silto arenosa (areia fina e média), vermelha, micácea, com fragmentos milimétricos de rocha. S.A.R.

Site argilo-arenoso (areia fina), verde com intercalaçäo decimétricas em amarelo, muito micácea - S.A.R.

Silte argilo-arenoso (areia fina), verde, muito micáceo - S.A.R.

Silte argilo-arenoso (areia fina e média) verde e amarelo, micáceo, com fragmentos milimétricos de rocha. S.A.R. 


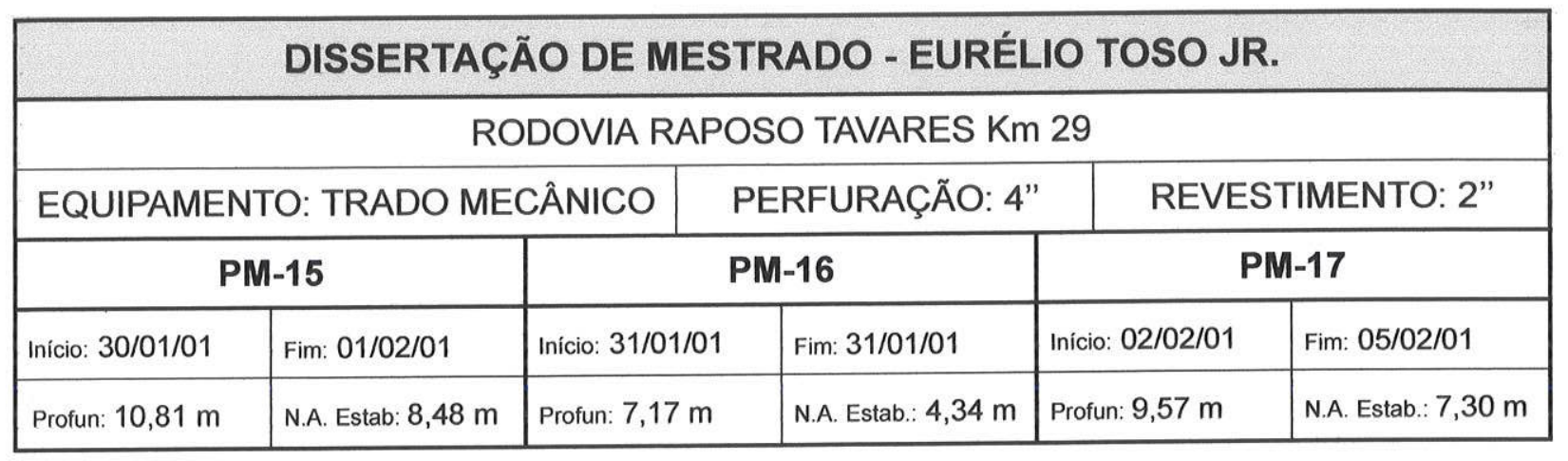

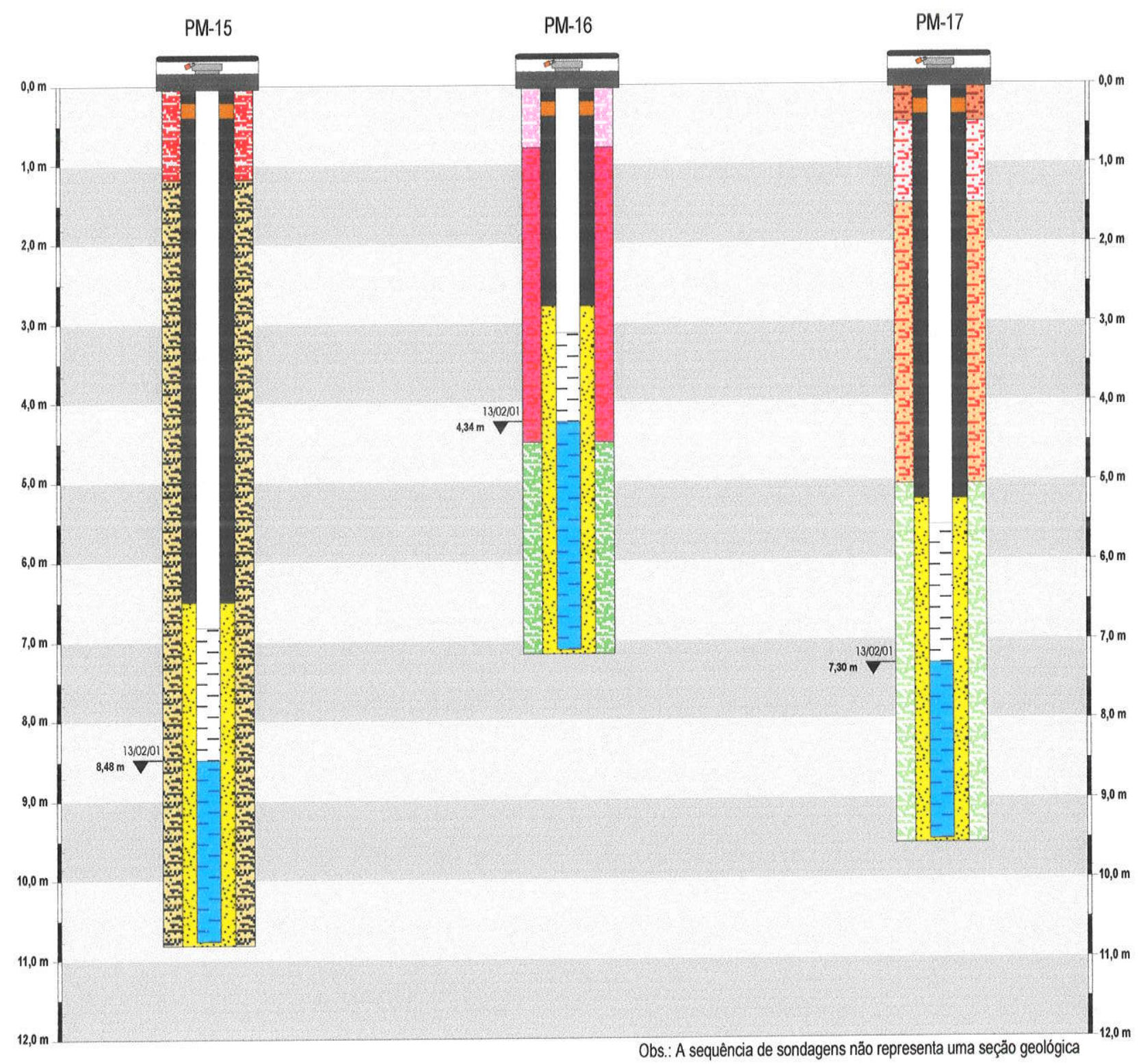

Legenda (Construtivo)

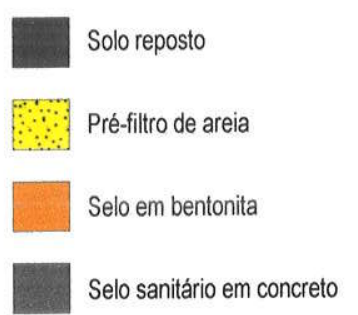

Legenda (Litologia)

Areia variada argilosa, com pedregulhos pequenos, vermelha, porosa - Aterro

Argila arenosa (areia variada), com pedegulhos de até $10 \mathrm{~cm}$, marrom, porosa - Aterro

Argila areno-siltosa (areia fina e média), cl pedregulhos pequenos, vermelha, pouco micácea - S.A.R. (Solo de Alteraçäo de Rocha)

$\therefore$ Argila silto-arenosa (areia variada c/ pedregulhos pequenos, vermelha e branca, pouco micácea - S.A.R.
Argila silto-arenosa (areia fina e média) vermelha, micácea - S.A.R. Argila silto-arenosa (areia variada), vermelha, micácea - S.A.R.

Silte argilo-arenoso (areia fina e média), cinza esverdeado, micáceo - S.A.R.

S.5. Silte areno-argiloso (areia fina), $\mathrm{c} /$ pedregulhos pequenos, W. bege, micáceo. A partir 2,40m, verde - S.A.R.

Silte argilo-arenoso (areia fina e média), verde, micáceo - S.A.R. 


\begin{tabular}{|l|l|l|l|}
\hline \multicolumn{4}{|c|}{ DISSERTAÇÃO DE MESTRADO - EURÉLIO TOSO JR. } \\
\hline \multicolumn{4}{|c|}{ RODOVIA RAPOSO TAVARES Km 29 } \\
\hline EQUIPAMENTO: TRADO MECÂNICO & \multicolumn{1}{c|}{ PERFURAÇÃO: 4" } & \multicolumn{1}{c|}{ REVESTIMENTO: 2" } \\
\hline \multicolumn{3}{|c|}{ PM-18 } & PM-19 \\
\hline Início: 02/02/01 & Fim: 05/05/01 & Início: 01/02/01 & Fim: 05/02/01 \\
\hline Profun: $7,10 \mathrm{~m}$ & N.A. Estab: $5,51 \mathrm{~m}$ & Profun: 3,06 m & N.A. Estab.: $1,70 \mathrm{~m}$ \\
\hline
\end{tabular}

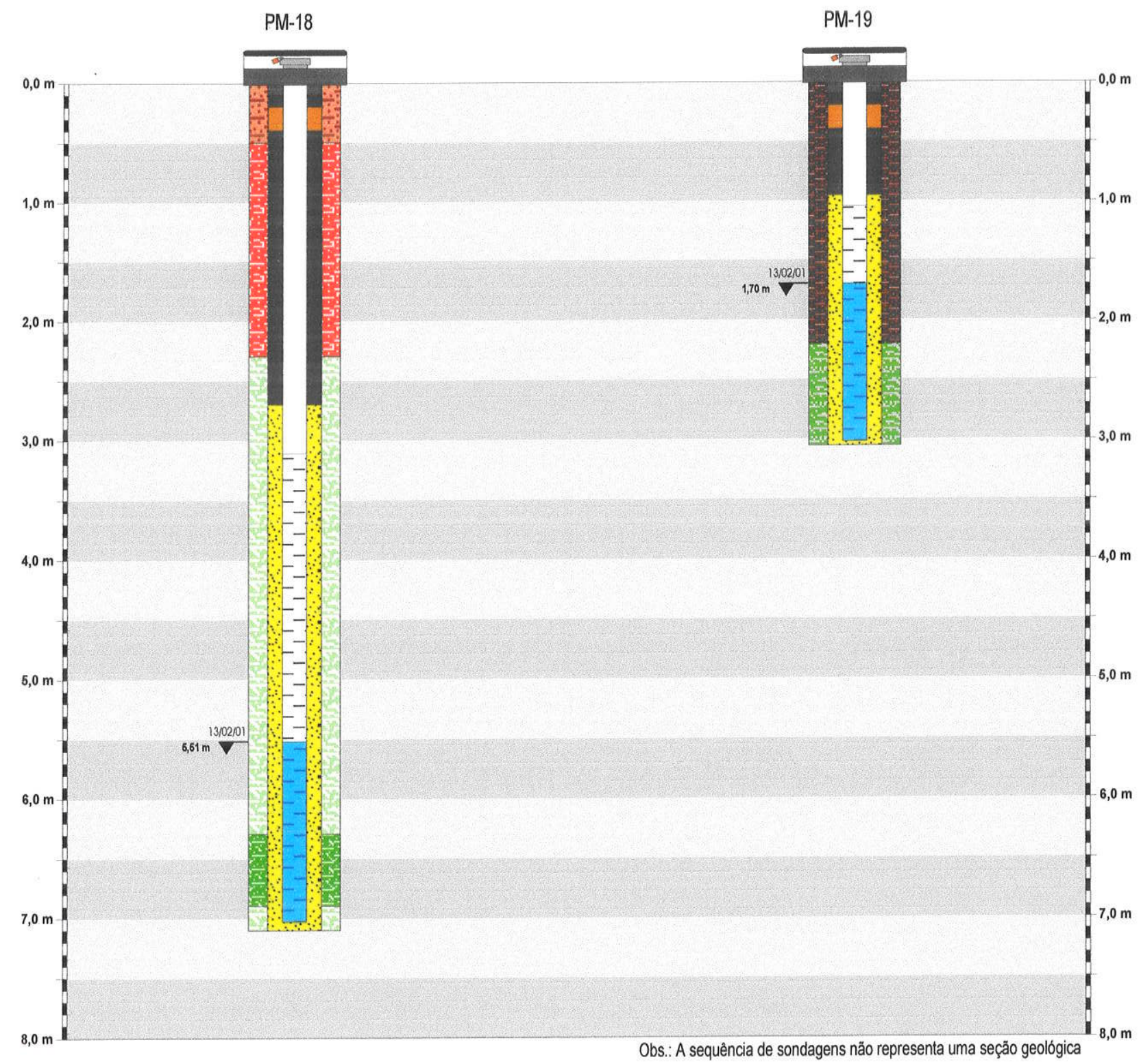

Legenda (Construtivo)

Solo reposto

Pré-filtro de areia

Selo em bentonita

Selo sanitário em concreto
Legenda (Litologia)

Pedregulhos centimétricos até decimétricos em solo argilo-arenoso - Aterro Argila arenosa (areia variada), com pedregulhos de até $10 \mathrm{~cm}$, marrom, porosa - Aterro Argila silto-arenosa (areia fina e média), com pedregulhos pequenos vermelha, micácea - S.A.R. Areia variada silto-argilosa, com pedregulhos de até $10 \mathrm{~cm}$, verde e branca, micácea - S.A.R. Silte argilo-srenoso (areia fina e média), verde, micáceo - S.A.R.

5. Silte areno-argiloso (areia fina), verde, micáceo - S.A.R. (Solo de Alteração de Rocha) 
ANEXO 02 


\section{SLUG TEST}

Poço: PM-06

Data: Fev/99

NA Estabilizado (m) : 2.85

N.A. após retirada do slug $(\mathrm{m}): 3.5$

Diâmetro do revestimento $(\mathrm{m}): 0.051$

Diâmetro do filtro $(\mathrm{m}): 0.1016$

Comprimento do filtro $(\mathrm{m}): 1.45$

$K=\frac{r^{2} \ln (L / R)}{2 L T_{0}}$

K é a Condutividade Hidráulica

onde : $\quad r$ é o raio do revestimento

$\mathrm{R}$ é o raio do filtro

L é o comprimento do filtro

T0 é o tempo que a água leva para atingir $37 \%$ da variação inicial

Do Gráfico

$\mathrm{TO}=961.8480706 \min$

\begin{tabular}{rll|}
\hline $\mathrm{K}=1.30 \mathrm{E}-06 \mathrm{~cm} / \mathrm{s}$ \\
\hline
\end{tabular}

\begin{tabular}{|c|c|c|}
\hline $\begin{array}{l}\text { Tempo } \\
\text { (min) }\end{array}$ & $h(m)$ & H-h/H-Ho \\
\hline 0 & 3.50 & 1 \\
\hline 1 & 3.50 & 1 \\
\hline 2 & 3.50 & 1 \\
\hline 3 & 3.50 & 1 \\
\hline 4 & 3.50 & 1 \\
\hline 5 & 3.49 & 0.984615385 \\
\hline 6 & 3.49 & 0.984615385 \\
\hline 7 & 3.49 & 0.984615385 \\
\hline 8 & 3.49 & 0.984615385 \\
\hline 9 & 3.49 & 0.984615385 \\
\hline 10 & 3.48 & 0.969230769 \\
\hline 12 & 3.48 & 0.969230769 \\
\hline 15 & 3.48 & 0.969230769 \\
\hline 20 & 3.47 & 0.953846154 \\
\hline 25 & 3.47 & 0.953846154 \\
\hline 30 & 3.47 & 0.953846154 \\
\hline 40 & 3.46 & 0.938461538 \\
\hline 50 & 3.46 & 0.938461538 \\
\hline 60 & 3.45 & 0.923076923 \\
\hline 70 & 3.45 & 0.923076923 \\
\hline 80 & 3.45 & 0.923076923 \\
\hline 90 & 3.44 & 0.907692308 \\
\hline 120 & 3.44 & 0.907692308 \\
\hline 150 & 3.43 & 0.892307692 \\
\hline 180 & 3.43 & 0.892307692 \\
\hline 210 & 3.42 & 0.876923077 \\
\hline 240 & 3.42 & 0.876923077 \\
\hline
\end{tabular}

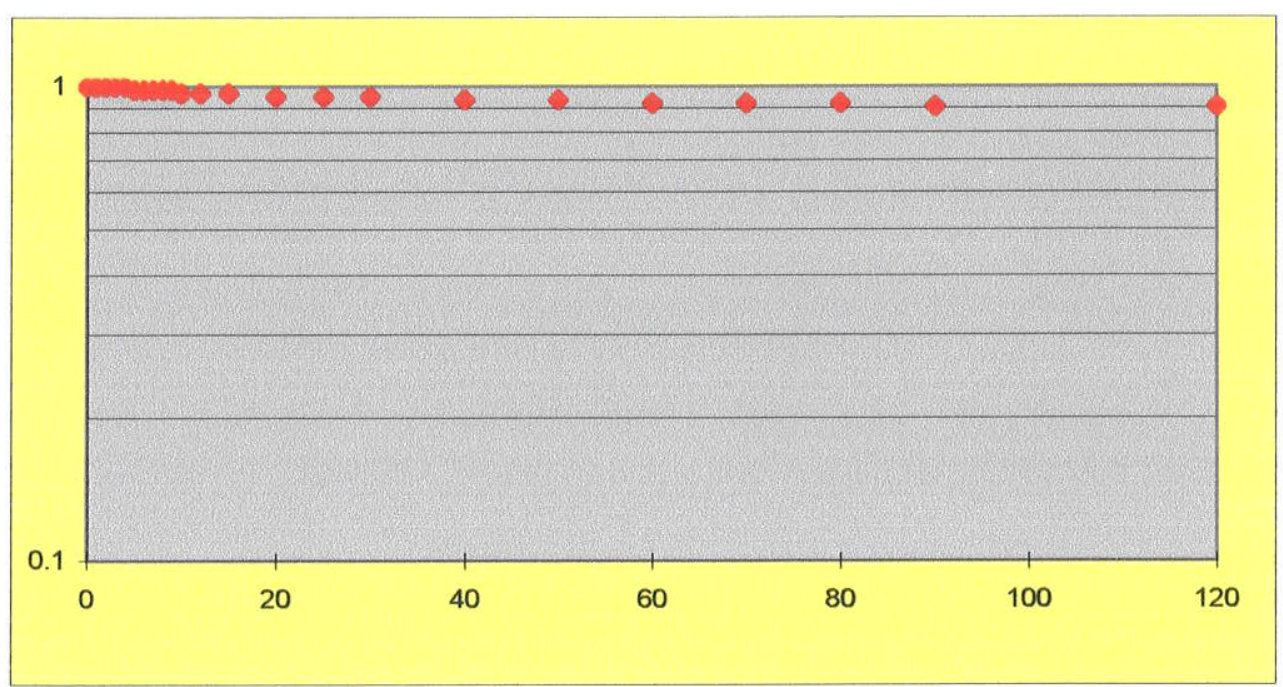




\section{SLUG TEST}

Poço: PM-13

Data: Fev/01

NA Estabilizado (m) : 2.15

N.A. após retirada do slug $(\mathrm{m}): 2.79$

Diâmetro do revestimento $(\mathrm{m}): 0.051$

Diâmetro do filtro $(\mathrm{m}): 0.1016$

Comprimento do filtro $(\mathrm{m}): 1.96$

$K=\frac{r^{2} \ln (L / R)}{2 L T_{0}}$

K é a Condutividade Hidráulica onde : $\quad r$ é o raio do revestimento

$R$ é o raio do filtro

L é o comprimento do filtro

TO é o tempo que a água leva para atingir $37 \%$ da variação inicial

Do Gráfico

$\mathrm{TO}=32.3733778 \mathrm{~min}$

$\mathrm{K}=3.12 \mathrm{E}-05 \mathrm{~cm} / \mathrm{s}$

\begin{tabular}{|c|c|c|}
\hline $\begin{array}{c}\text { Tempo } \\
\text { (min) }\end{array}$ & $h(m)$ & H-h/H-Ho \\
\hline 0 & 2.79 & 1 \\
\hline 1 & 2.74 & 0.921875 \\
\hline 2 & 2.70 & 0.859375 \\
\hline 3 & 2.66 & 0.796875 \\
\hline 4 & 2.62 & 0.734375 \\
\hline 5 & 2.59 & 0.6875 \\
\hline 6 & 2.56 & 0.640625 \\
\hline 7 & 2.53 & 0.59375 \\
\hline 8 & 2.50 & 0.546875 \\
\hline 9 & 2.47 & 0.5 \\
\hline 10 & 2.45 & 0.46875 \\
\hline 12 & 2.42 & 0.421875 \\
\hline 15 & 2.39 & 0.375 \\
\hline 20 & 2.37 & 0.34375 \\
\hline 25 & 2.34 & 0.296875 \\
\hline 30 & 2.31 & 0.25 \\
\hline 40 & 2.29 & 0.21875 \\
\hline 50 & 2.26 & 0.171875 \\
\hline 60 & 2.23 & 0.125 \\
\hline 70 & 2.22 & 0.109375 \\
\hline 80 & 2.19 & 0.0625 \\
\hline 90 & 2.16 & 0.015625 \\
\hline & & \\
\hline & & \\
\hline & & \\
\hline
\end{tabular}

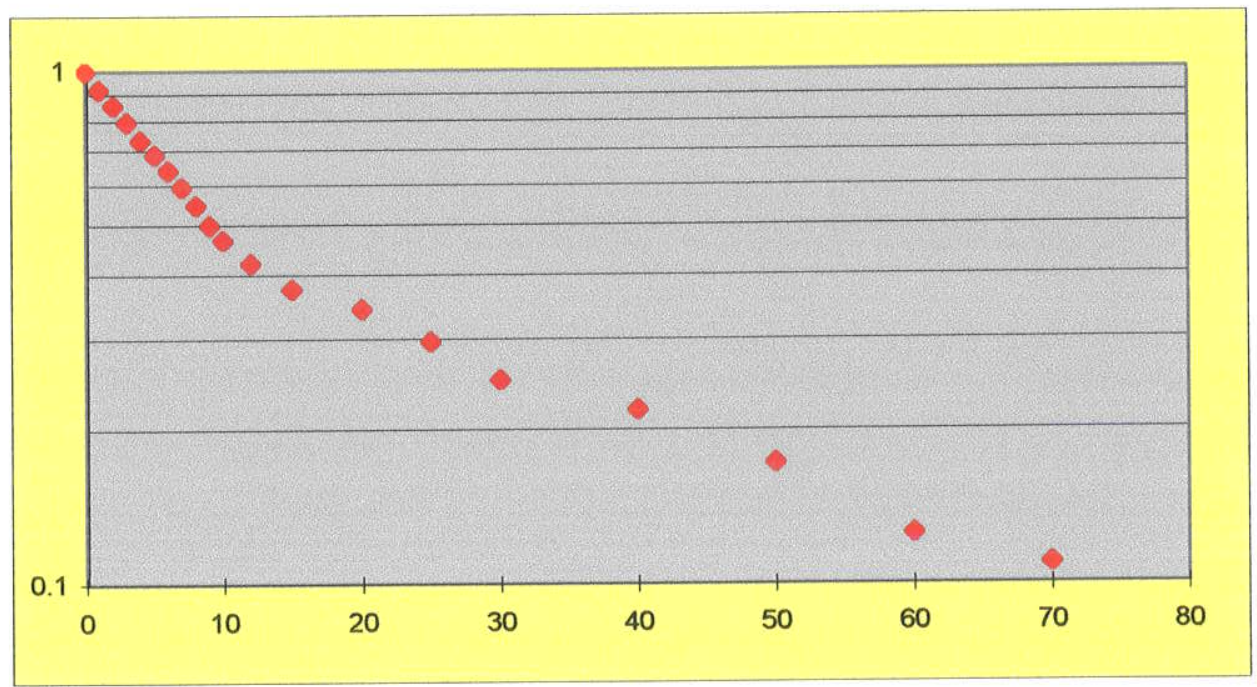




\section{SLUG TEST}

Poço: PM-14

Data: Fev/01

NA Estabilizado $(\mathrm{m}): 2.61$

N.A. após retirada do slug $(\mathrm{m}): 3.25$

Diâmetro do revestimento $(\mathrm{m}): 0.051$

Diâmetro do filtro $(\mathrm{m}): 0.1016$

Comprimento do filtro $(\mathrm{m}): 1.95$

$K=\frac{r^{2} \ln (L / R)}{2 L T_{0}}$

K é a Condutividade Hidráulica

onde : $\quad r$ é o raio do revestimento

$\mathrm{R}$ é o raio do filtro

L é o comprimento do filtro

T0 é o tempo que a água leva para

atingir $37 \%$ da variação inicial

Do Gráfico

$\mathrm{TO}=100.014566 \mathrm{~min}$

$\mathrm{K}=1.01 \mathrm{E}-05 \mathrm{~cm} / \mathrm{s}$

\begin{tabular}{|c|c|c|}
\hline $\begin{array}{c}\text { Tempo } \\
\text { (min) }\end{array}$ & $h(m)$ & H-h/H-Ho \\
\hline 0 & 3.25 & 1 \\
\hline 1 & 3.24 & 0.984375 \\
\hline 2 & 3.23 & 0.96875 \\
\hline 3 & 3.22 & 0.953125 \\
\hline 4 & 3.21 & 0.9375 \\
\hline 5 & 3.20 & 0.921875 \\
\hline 6 & 3.19 & 0.90625 \\
\hline 7 & 3.18 & 0.890625 \\
\hline 8 & 3.17 & 0.875 \\
\hline 9 & 3.16 & 0.859375 \\
\hline 10 & 3.15 & 0.84375 \\
\hline 12 & 3.14 & 0.828125 \\
\hline 15 & 3.12 & 0.796875 \\
\hline 20 & 3.10 & 0.765625 \\
\hline 25 & 3.08 & 0.734375 \\
\hline 30 & 3.06 & 0.703125 \\
\hline 40 & 3.04 & 0.671875 \\
\hline 50 & 3.02 & 0.640625 \\
\hline 60 & 3.00 & 0.609375 \\
\hline 70 & 2.98 & 0.578125 \\
\hline 80 & 2.96 & 0.546875 \\
\hline 90 & 2.94 & 0.515625 \\
\hline 120 & 2.91 & 0.46875 \\
\hline 150 & 2.87 & 0.40625 \\
\hline 180 & 2.84 & 0.359375 \\
\hline 210 & 2.8 & 0.296875 \\
\hline 240 & 2.77 & 0.25 \\
\hline
\end{tabular}

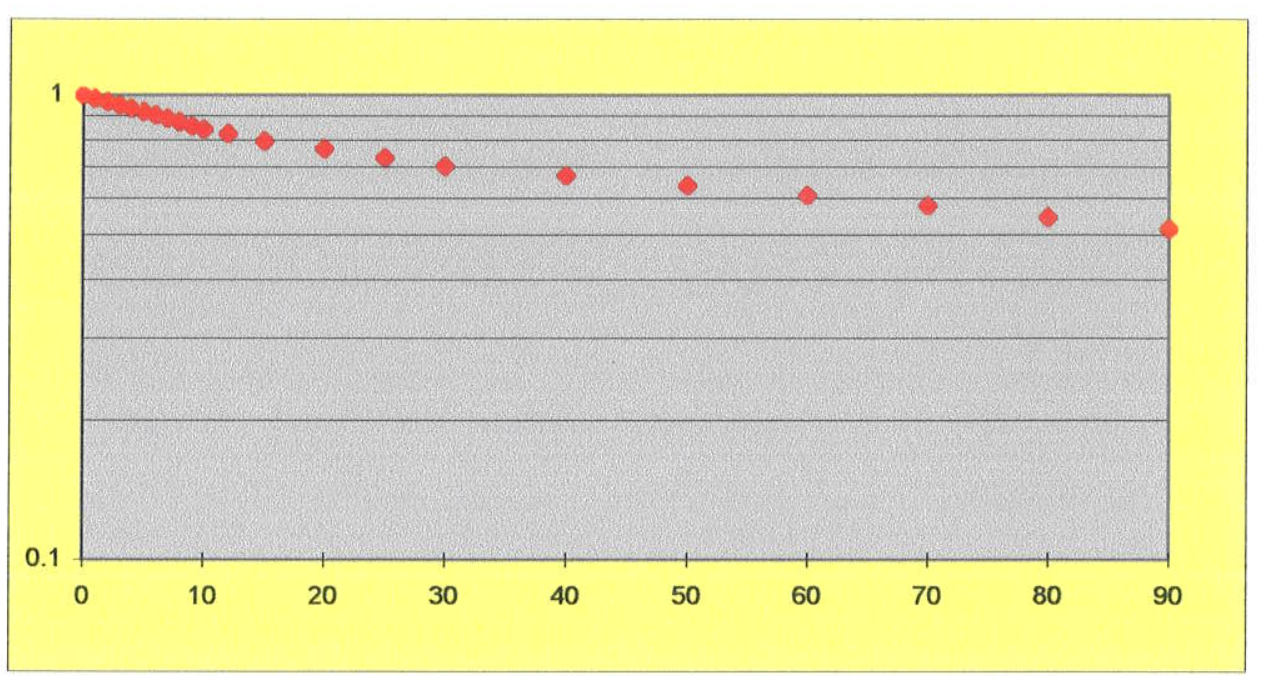




\section{SLUG TEST}

Poço: PM-18

Data: Fev/01

NA Estabilizado (m) : 5.51

N.A. após retirada do slug $(\mathrm{m}): 6.15$

Diâmetro do revestimento $(\mathrm{m}): 0.051$

Diâmetro do filtro $(\mathrm{m}): 0.1016$

Comprimento do filtro $(\mathrm{m}): 1.59$

$K=\frac{r^{2} \ln (L / R)}{2 L T_{0}}$

K é a Condutividade Hidráulica

onde: $\quad r$ é o raio do revestimento

$\mathrm{R}$ é o raio do filtro

L é o comprimento do filtro

TO é o tempo que a água leva para

atingir $37 \%$ da variação inicial

Do Gráfico

$\mathrm{TO}=22.1365395 \quad \min$

$\mathrm{K}=5.30 \mathrm{E}-05 \mathrm{~cm} / \mathrm{s}$

\begin{tabular}{|c|c|c|}
\hline $\begin{array}{c}\text { Tempo } \\
\text { (min) }\end{array}$ & $h(m)$ & H-h/H-Ho \\
\hline 0 & 6.15 & 1 \\
\hline 1 & 6.11 & 0.9375 \\
\hline 2 & 6.08 & 0.890625 \\
\hline 3 & 6.05 & 0.84375 \\
\hline 4 & 6.02 & 0.796875 \\
\hline 5 & 5.99 & 0.75 \\
\hline 6 & 5.96 & 0.703125 \\
\hline 7 & 5.93 & 0.65625 \\
\hline 8 & 5.90 & 0.609375 \\
\hline 9 & 5.88 & 0.578125 \\
\hline 10 & 5.85 & 0.53125 \\
\hline 12 & 5.82 & 0.484375 \\
\hline 15 & 5.79 & 0.4375 \\
\hline 20 & 5.75 & 0.375 \\
\hline 25 & 5.72 & 0.328125 \\
\hline 30 & 5.69 & 0.28125 \\
\hline 40 & 5.66 & 0.234375 \\
\hline 50 & 5.63 & 0.1875 \\
\hline 60 & 5.60 & 0.140625 \\
\hline 70 & 5.57 & 0.09375 \\
\hline 80 & 5.55 & 0.0625 \\
\hline 90 & 5.53 & 0.03125 \\
\hline 120 & 5.52 & 0.015625 \\
\hline 140 & 5.51 & 0 \\
\hline & & \\
\hline & & \\
\hline
\end{tabular}

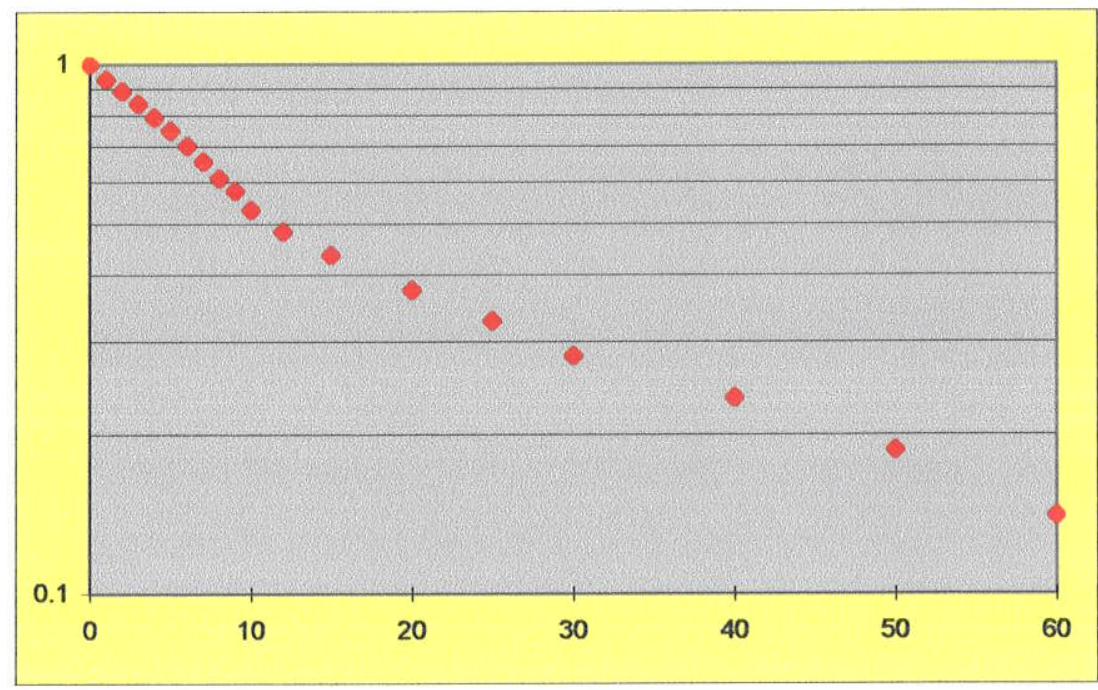


ANEXO 03

Simulações de Transporte 


\title{
Calibração do Modelo / Fonte A - PM-11
}

\author{
$==$ Reading Input File \\ NUMBER OF YEARS SIMULATED: 50 \\ $==$ Initializing Data \\ Deterministic Run
}

SIMULATION FOR CHEMICAL Lead

Run number $\quad 1$

Running AT123D

Year 1.0 avg. conc. $[\mathrm{mg} / \mathrm{l}]=.000$

Year 2.0 avg. conc. $[\mathrm{mg} / \mathrm{l}]=.243 \mathrm{E}-02$

Year 3.0 avg. conc. $[\mathrm{mg} /]=.373$

Year 4.0 avg. conc. $[\mathrm{mg} /]]=1.49$

Year 5.0 avg. conc. $[\mathrm{mg} / \mathrm{l}]=2.30$

Year 6.0 avg. conc. $[\mathrm{mg} /]=2.42$

Year 7.0 avg. conc. $[\mathrm{mg} /]]=2.10$

Year 8.0 avg. conc. $[\mathrm{mg} /]=1.63$

Year 9.0 avg. conc. $[\mathrm{mg} /]=1.20$

Year 10.0 avg. conc. $[\mathrm{mg} / \mathrm{l}]=.840$

Year 11.0 avg. conc. $[\mathrm{mg} /]=.574$

Year 12.0 avg. conc. $[\mathrm{mg} / \mathrm{l}]=.386$

Year 13.0 avg. conc. $[\mathrm{mg} / \mathrm{l}]=.256$

Year 14.0 avg. conc. $[\mathrm{mg} /]=.168$

Year 15.0 avg. conc. $[\mathrm{mg} /]=.110$

Year 16.0 avg. conc. $[\mathrm{mg} /]=.711 \mathrm{E}-01$

Year 17.0 avg. conc. $[\mathrm{mg} /]=.460 \mathrm{E}-01$

Year 18.0 avg. conc. $[\mathrm{mg} /]]=.297 \mathrm{E}-01$

Year 19.0 avg. conc. $[\mathrm{mg} /]=.192 \mathrm{E}-01$

Year 20.0 avg. conc. $[\mathrm{mg} / \mathrm{l}]=.123 \mathrm{E}-01$

Year 21.0 avg. conc. $[\mathrm{mg} / \mathrm{l}]=.793 \mathrm{E}-02$

Year 22.0 avg. conc. $[\mathrm{mg} / \mathrm{l}]=.510 \mathrm{E}-02$

Year 23.0 avg. conc. $[\mathrm{mg} / \mathrm{l}]=.328 \mathrm{E}-02$

Year 24.0 avg. conc. $[\mathrm{mg} /]=.211 \mathrm{E}-02$

Year 25.0 avg. conc. $[\mathrm{mg} / \mathrm{l}]=.135 \mathrm{E}-02$

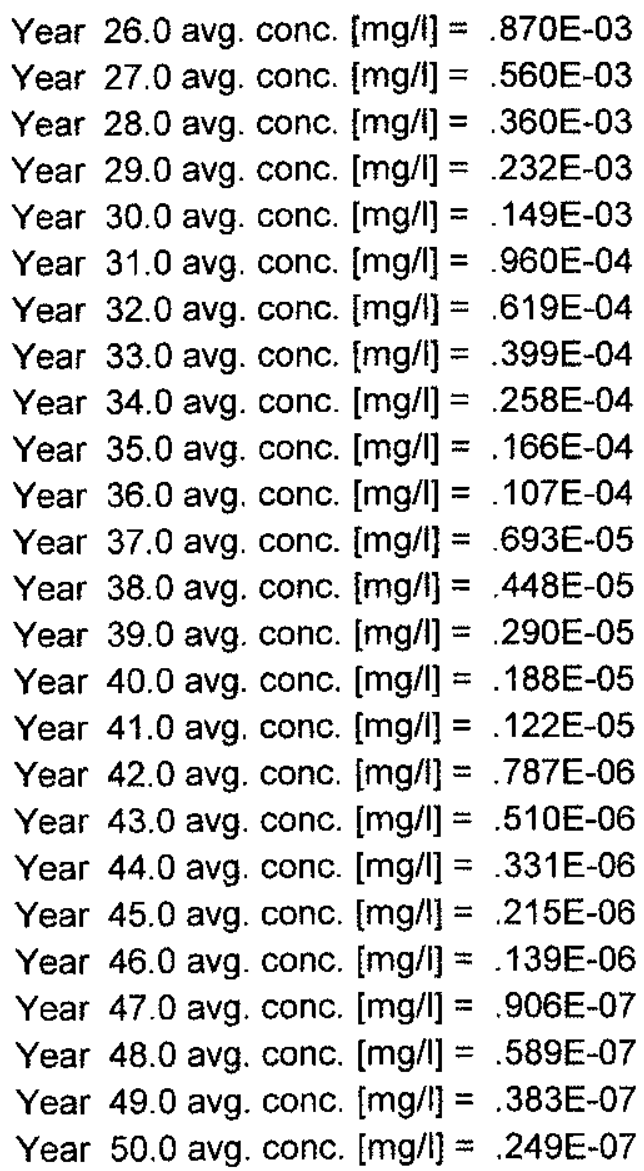

AT123D RUN COMPLETED

Simulation Finished 


\section{Calibração do Modelo / Fonte A - PM-11}

AT123D Output File

Analysis for ...

Chemicals in the analysis: Lead

Number of years simulated:

50

GENERAL INPUT DATA

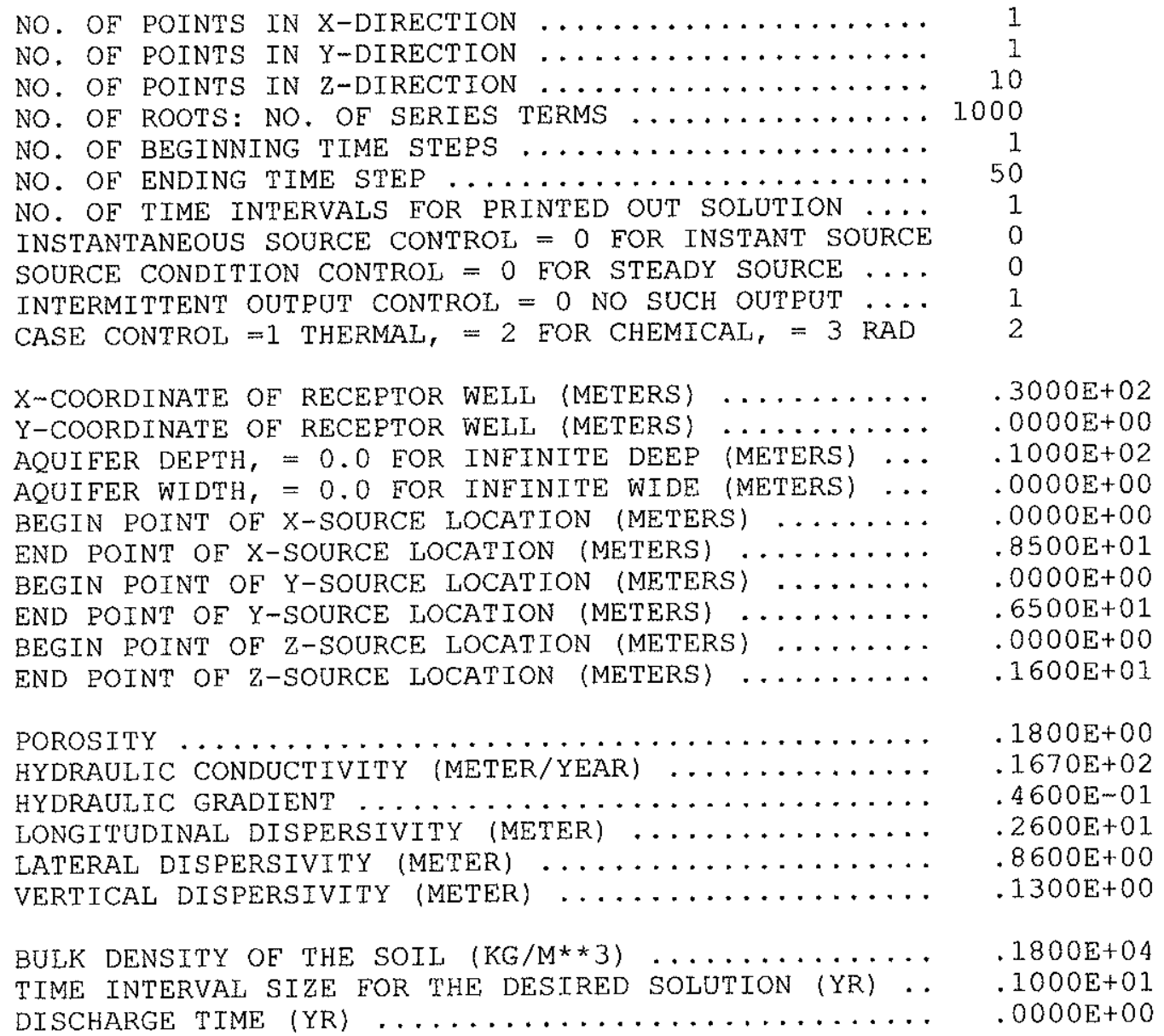

INPUT DATA/RESULTS FOR CHEMICAL: Lead

INST. WASTE RELEASE (KG) VALID FOR INST CASE ONLY.. .7600E+00 DISTRIBUTION COEEEICIENT, KD $(M * * 3 / K G) \ldots \ldots \ldots \ldots . .0000 E+00$ MOLECULAR DIFEUSTON COEFEICIENT $\quad(M * 2 / Y R) \quad .0000 E+00$

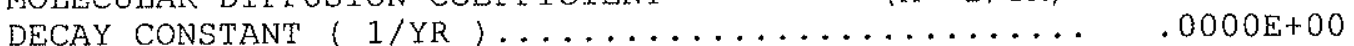

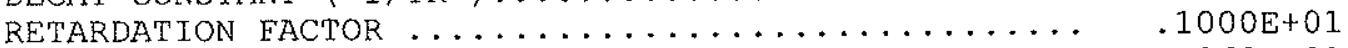
RETARDED SEEPAGE VELOCITY (M/YR) ............ .4268E+01 RETARDED LONGITUDINAL DISPERSION COEF $\quad(M * * 2 / Y R) \quad \ldots \quad .1110 \mathrm{M}+02$ RETARDED LATERAL DISPERSTON COEEFICIENT $(M * * 2 / Y R) \quad$. $\quad .3670 E+01$ RETARDED VERTICAL DISPERSION COEFFICIENT $\left(\mathrm{M}^{*} * 2 / \mathrm{YR}\right) . \quad .5548 \mathrm{E}+00$ 


\section{Calibração do Modelo / PM-18 - PM-11}

$==$ Reading Input File

NUMBER OF YEARS SIMULATED: 100

$==$ Initializing Data

Deterministic Run

SIMULATION FOR CHEMICAL Lead

Run number 1

Running AT123D

Year 1.0 avg. conc. $[\mathrm{mg} / \mathrm{l}]=.000$

Year $2.0 \mathrm{avg}$. conc. $[\mathrm{mg} / \mathrm{l}]=.859$

Year 3.0 avg. conc. $[\mathrm{mg} / \mathrm{l}]=1.84$

Year 4.0 avg. conc. $[\mathrm{mg} /]=1.54$

Year 5.0 avg. conc. $[\mathrm{mg} /]=.876$

Year 6.0 avg. conc. $[\mathrm{mg} /]=.413$

Year 7.0 avg. conc. $[\mathrm{mg} / 1]=.176$

Year 8.0 avg. conc. $[\mathrm{mg} / \mathrm{l}]=.707 \mathrm{E}-01$

Year 9.0 avg. conc. $[\mathrm{mg} /]=.274 \mathrm{E}-01$

Year 10.0 avg. conc. $[\mathrm{mg} /]=.104 \mathrm{E}-01$

Year 11.0 avg. conc. $[\mathrm{mg} /]=.388 \mathrm{E}-02$

Year 12.0 avg. conc. $[\mathrm{mg} /]=.143 \mathrm{E}-02$

Year 13.0 avg. conc. $[\mathrm{mg} / \mathrm{l}]=.527 \mathrm{E}-03$

Year 14.0 avg. conc. $[\mathrm{mg} /]=.193 \mathrm{E}-03$

Year 15.0 avg. conc. $[\mathrm{mg} /]=.705 \mathrm{E}-04$

Year 16.0 avg. conc. $[\mathrm{mg} / \mathrm{l}]=.257 \mathrm{E}-04$

Year 17.0 avg. conc. $[\mathrm{mg} / \mathrm{l}]=.934 \mathrm{E}-05$

Year 18.0 avg. conc. $[\mathrm{mg} /]]=.340 \mathrm{E}-05$

Year 19.0 avg. conc. $[\mathrm{mg} / \mathrm{l}]=.124 \mathrm{E}-05$

Year 20.0 avg. conc. $[\mathrm{mg} / \mathrm{l}]=.450 \mathrm{E}-06$

Year 21.0 avg. conc. $[\mathrm{mg} /]=.164 \mathrm{E}-06$

Year 22.0 avg. conc. $[\mathrm{mg} / \mathrm{l}]=.596 \mathrm{E}-07$

Year 23.0 avg. conc. $[\mathrm{mg} / \mathrm{l}]=.217 \mathrm{E}-07$

Year 24.0 avg. conc. $[\mathrm{mg} / \mathrm{l}]=.000$

Year 25.0 avg. conc. $[\mathrm{mg} / \mathrm{l}]=.000$
Year 26.0 avg. conc. $[\mathrm{mg} /]=.000$

Year $27.0 \mathrm{avg}$. conc. $[\mathrm{mg} / \mathrm{l}]=.000$

Year 28.0 avg. conc. $[\mathrm{mg} /]=.000$

Year 29.0 avg. conc. $[\mathrm{mg} / \mathrm{l}]=.000$

Year 30.0 avg. conc. $[\mathrm{mg} /]=.000$

Year 31.0 avg. conc. $[\mathrm{mg} /]=.000$

Year 32.0 avg. conc. $[\mathrm{mg} /]=.000$

Year 33.0 avg. conc. $[\mathrm{mg} / \mathrm{l}]=.000$

Year 34.0 avg. conc. $[\mathrm{mg} / \mathrm{l}]=.000$

Year 35.0 avg. conc. $[\mathrm{mg} /]=.000$

Year 36.0 avg. conc. $[\mathrm{mg} /]]=.000$

Year 37.0 avg. conc. $[\mathrm{mg} / \mathrm{l}]=.000$

Year 38.0 avg. conc. $[\mathrm{mg} / \mathrm{l}]=.000$

Year 39.0 avg. conc. $[\mathrm{mg} / \mathrm{l}]=.000$

Year 40.0 avg. conc. $[\mathrm{mg} / \mathrm{l}]=.000$

Year 41.0 avg. conc. $[\mathrm{mg} /]]=.000$

Year 42.0 avg. conc. $[\mathrm{mg} / \mathrm{l}]=.000$

Year 43.0 avg. conc. $[\mathrm{mg} / \mathrm{l}]=.000$

Year 44.0 avg. conc. $[\mathrm{mg} /]=.000$

Year 45.0 avg. conc. $[\mathrm{mg} /]=.000$

Year 46.0 avg. conc. $[\mathrm{mg} /]=.000$

Year 47.0 avg. conc. $[\mathrm{mg} / \mathrm{l}]=.000$

Year 48.0 avg. conc. $[\mathrm{mg} / \mathrm{l}]=.000$

Year 49.0 avg. conc. $[\mathrm{mg} / \mathrm{l}]=.000$

Year 50.0 avg. conc. $[\mathrm{mg} / \mathrm{l}]=.000$

AT123D RUN COMPLETED

SimulationFinished 
A 123D Output File

Analysis for ...

Chemicals in the analysis

Lead

Number of years simulated:

100

GENERAL INPUT DATA

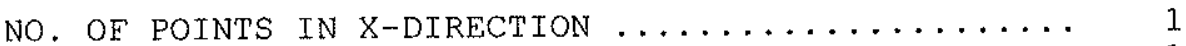

NO. OF POINTS IN $Y$-DIRECTION $\ldots \ldots \ldots \ldots \ldots \ldots \ldots \ldots \ldots$

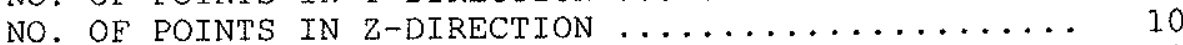

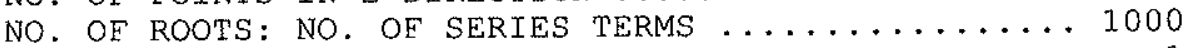

NO. OF BEGINNING TIME STEPS $\ldots \ldots \ldots \ldots \ldots \ldots \ldots \ldots \ldots \ldots$

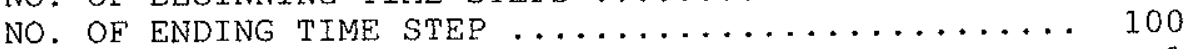

NO. OF TIME INTERVALS FOR PRINTED OUT SOLUTION .... 1

INSTANTANEOUS SOURCE CONTROL $=0$ FOR INSTANT SOURCE 0

SOURCE CONDITION CONTROL $=0$ FOR STEADY SOURCE $\ldots . . .0$

INTERMITTENT OUTPUT CONTROL $=0$ NO SUCH OUTPUT $\ldots . . .1$

CASE CONTROL $=1$ THERMAL, $=2$ FOR CHEMICAL, $=3$ RAD 2

$X$-COORDINATE OE RECEPTOR WELL (METERS) ........ . $1600 E+02$

Y-COORDINATE OF RECEPTOR WELL (METERS) .......... .0000E+00

AOUTFER DEPTH, $=0.0$ FOR INFINITE DEEP (METERS) $\ldots . .1000 \mathrm{E}+02$

AQUIEER WIDTH, $=0.0$ FOR INEINITE WIDE (METERS) $\ldots . .0000 E+00$

BEGIN POINT OE X-SOURCE LOCATION (METERS) ....... . . . . . . .

END POINT OE $X$-SOURCE LOCATION (METERS) ......... . . . . . . . . . . 002 .

BEGIN POIN'T OE $Y$-SOURCE LOCATION (METERS) ........ . . . . . . . .

END POINT OE Y-SOURCE LOCATION (METERS) ........... . $7000 E+01$

BEGIN POINT OF Z-SOURCE LOCATION (METERS) ........ . . 0000E+00

END POINT OF $Z$-SOURCE LOCATION (METERS) ......... .1600E+01

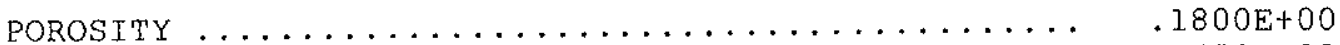

HYDRAULIC CONDUCTIVTTY (METER/YEAR) .......... .1670E+02

HYDRAULIC GRADTENT ................... .4600E-01

LONGITUDINAL DISPERSIVITY (METER) ............ .1100E+01

LATERAL DISPERSIVITY (METER) ............. .3600E+00

VERTICAL DISPERSIVITY (METER) .............. .5500E-01

BULK DENSITY OF THE SOIL $(K G / M * * 3) \ldots \ldots \ldots \ldots \ldots \ldots \ldots$. $1800 \mathrm{\ldots}+04$ TIME INTERVAL SIZE FOR THE DESIRED SOLUTION (YR) . . .1000E+01 DISCHARGE TIME (YR) ..................... .0000E+00

INPUT DATA/RESULTS FOR CHEMICAL: Lead

INST. WASTE RELEASE (KG) VALID FOR INST CASE ONLY.. DISTRIBUTION COEFEICIENT, KD $(M * * 3 / K G) \ldots \ldots \ldots \ldots$

$1310 \mathrm{E}+00$ $.0000 \mathrm{E}+00$ MOLECULAR DIEEUSION COEFEICIENT $(M * * 2 / Y R)$

$.0000 \mathrm{E}+00$

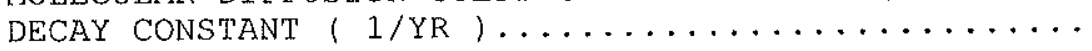
$.0000 \mathrm{E}+00$

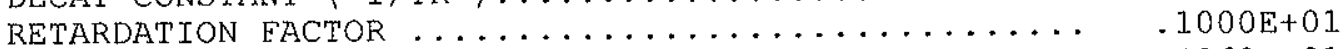
RETARDED SEEPAGE VELOCITY (M/YR) ............ .4268E+01 RETARDED LONGITUDTNAL DISPERSION COEF. $\left(\mathrm{M}^{*} * 2 / \mathrm{YR}\right) \quad \ldots \quad .4695 \mathrm{E}+01$ RETARDED IATERAL DISPERSION COEEFICIENT $\left(\mathrm{M}^{*} * 2 / \mathrm{YR}\right) \cdot \quad .1536 \mathrm{E}+01$ RETARDED VERTICAL, DISPERSION COEFEICIENT $(M * * 2 / Y R) . \quad .2347 \mathrm{E}+00$ 


\section{Fonte B - Receptor 90 m}

$==$ Reading Input File

NUMBER OF YEARS SIMULATED: 100

$==$ Initializing Data

Deterministic Run

SIMULATION FOR CHEMICAL Lead
Run number

Running AT123D

Year 1.0 avg. conc. $[\mathrm{mg} / \mathrm{l}]=.000$

Year 2.0 avg. conc. $[\mathrm{mg} /]]=.000$

Year 3.0 avg. conc. $[\mathrm{mg} /]=.000$

Year 4.0 avg. conc. $[\mathrm{mg} /]=.000$

Year 5.0 avg. conc. $[\mathrm{mg} /]]=.000$

Year 6.0 avg. conc. $[\mathrm{mg} / \mathrm{l}]=.484 \mathrm{E}-06$

Year 7.0 avg. conc. $[\mathrm{mg} / \mathrm{l}]=.885 \mathrm{E}-05$

Year $8.0 \mathrm{avg}$. conc. $[\mathrm{mg} / \mathrm{l}]=.684 \mathrm{E}-04$

Year 9.0 avg. conc. $[\mathrm{mg} /]=.308 \mathrm{E}-03$

Year 10.0 avg. conc. $[\mathrm{mg} /]=.969 \mathrm{E}-03$

Year 11.0 avg. conc. $[\mathrm{mg} /]=.237 \mathrm{E}-02$

Year 12.0 avg. conc. $[\mathrm{mg} / \mathrm{l}]=.483 \mathrm{E}-02$

Year 13.0 avg. conc. $[\mathrm{mg} / \mathrm{l}]=.859 \mathrm{E}-02$

Year 14.0 avg. conc. $[\mathrm{mg} / \mathrm{l}]=.138 \mathrm{E}-01$

Year 15.0 avg. conc. $[\mathrm{mg} / \mathrm{l}]=.203 \mathrm{E}-01$

Year 16.0 avg. conc. $[\mathrm{mg} /]=.281 \mathrm{E}-01$

Year $17.0 \mathrm{avg}$. conc. $[\mathrm{mg} / \mathrm{l}]=.368 \mathrm{E}-01$

Year 18.0 avg. conc. $[\mathrm{mg} / 1]=.462 \mathrm{E}-01$

Year 19.0 avg. conc. $[\mathrm{mg} /]=.560 \mathrm{E}-01$

Year 20.0 avg. conc. $[\mathrm{mg} /]=.659 \mathrm{E}-01$

Year 21.0 avg. conc. $[\mathrm{mg} / \mathrm{l}]=.756 \mathrm{E}-01$

Year 22.0 avg. conc. $[\mathrm{mg} /]=.849 \mathrm{E}-01$

Year 23.0 avg. conc. $[\mathrm{mg} / \mathrm{l}]=.936 \mathrm{E}-01$

Year 24.0 avg. conc. $[\mathrm{mg} /]=.102$

Year 25.0 avg. conc. $[\mathrm{mg} / \mathrm{l}]=.109$

Year 26.0 avg. conc. $[\mathrm{mg} /]=.115$

Year 27.0 avg. conc. $[\mathrm{mg} / \mathrm{l}]=.121$

Year 28.0 avg. conc. $[\mathrm{mg} /]=.125$

Year 29.0 avg. conc. $[\mathrm{mg} /]=.129$

Year 30.0 avg. conc. $[\mathrm{mg} /]=.132$

Year 31.0 avg. conc. $[\mathrm{mg} / \mathrm{l}]=.134$

Year 32.0 avg. conc. $[\mathrm{mg} /]]=.135$

Year 33.0 avg. conc. $[\mathrm{mg} / \mathrm{l}]=.136$

Year 34.0 avg. conc. $[\mathrm{mg} / \mathrm{l}]=.136$

Year 35.0 avg. conc. $[\mathrm{mg} /]=.135$

Year 36.0 avg. conc. $[\mathrm{mg} /]=.134$

Year 37.0 avg. conc. $[\mathrm{mg} / \mathrm{l}]=.133$

Year 38.0 avg. conc. $[\mathrm{mg} / \mathrm{l}]=.131$

Year 39.0 avg. conc. $[\mathrm{mg} / \mathrm{l}]=.129$

Year 40.0 avg. conc. $[\mathrm{mg} / \mathrm{l}]=.126$

Year 41.0 avg. conc. $[\mathrm{mg} / \mathrm{l}]=.123$

Year 42.0 avg. conc. $[\mathrm{mg} / \mathrm{l}]=.120$

Year 43.0 avg. conc. $[\mathrm{mg} / \mathrm{l}]=.117$

Year 44.0 avg. conc. $[\mathrm{mg} /]=.114$

Year 45.0 avg. conc. $[\mathrm{mg} / \mathrm{l}]=.110$

Year 46.0 avg. conc. $[\mathrm{mg} / \mathrm{l}]=.107$

Year 47.0 avg. conc. $[\mathrm{mg} /]]=.103$

Year 48.0 avg. conc. $[\mathrm{mg} /]]=.996 \mathrm{E}-01$

Year 49.0 avg. conc. $[\mathrm{mg} / \mathrm{l}]=.960 \mathrm{E}-01$

Year 50.0 avg. conc. $[\mathrm{mg} / 1]=.924 \mathrm{E}-01$

Year 51.0 avg. conc. $[\mathrm{mg} / \mathrm{l}]=.888 \mathrm{E}-01$

Year 52.0 avg. conc. $[\mathrm{mg} /]=.853 \mathrm{E}-01$

Year 53.0 avg. conc. $[\mathrm{mg} /]]=.818 \mathrm{E}-01$

Year 54.0 avg. conc. $[\mathrm{mg} / \mathrm{l}]=.784 \mathrm{E}-01$

Year 55.0 avg. conc. $[\mathrm{mg} / \mathrm{l}]=.750 \mathrm{E}-01$

Year 56.0 avg. conc. $[\mathrm{mg} / \mathrm{l}]=.718 \mathrm{E}-01$

Year 57.0 avg. conc. $[\mathrm{mg} /]=.686 \mathrm{E}-01$

Year 58.0 avg. conc. $[\mathrm{mg} / \mathrm{l}]=.655 \mathrm{E}-01$

Year 59.0 avg. conc. $[\mathrm{mg} / \mathrm{l}]=.625 \mathrm{E}-01$

Year 60.0 avg. conc. $[\mathrm{mg} / \mathrm{l}]=.596 \mathrm{E}-01$ 
Year 61.0 avg. conc. $[\mathrm{mg} / \mathrm{l}]=.568 \mathrm{E}-01$

Year 62.0 avg. conc. $[\mathrm{mg} /]=.541 \mathrm{E}-01$

Year 63.0 avg. conc. $[\mathrm{mg} / \mathrm{l}]=.515 \mathrm{E}-01$

Year 64.0 avg. conc. $[\mathrm{mg} / \mathrm{l}]=.490 \mathrm{E}-01$

Year 65.0 avg. conc. $[\mathrm{mg} /]=.465 \mathrm{E}-01$

Year 66.0 avg. conc. $[\mathrm{mg} /]=.442 \mathrm{E}-01$

Year 67.0 avg. conc. $[\mathrm{mg} / \mathrm{l}]=.420 \mathrm{E}-01$

Year 68.0 avg. conc. $[\mathrm{mg} /]=.399 \mathrm{E}-01$

Year 69.0 avg. conc. $[\mathrm{mg} / \mathrm{l}]=.378 \mathrm{E}-01$

Year 70.0 avg. conc. $[\mathrm{mg} /]=.359 \mathrm{E}-01$

Year 71.0 avg. conc. $[\mathrm{mg} /]=.340 \mathrm{E}-01$

Year 72.0 avg. conc. $[\mathrm{mg} / \mathrm{l}]=.322 \mathrm{E}-01$

Year 73.0 avg. conc. $[\mathrm{mg} / \mathrm{l}]=.305 \mathrm{E}-01$

Year 74.0 avg. conc. $[\mathrm{mg} / \mathrm{l}]=.289 \mathrm{E}-01$

Year 75.0 avg. conc. $[\mathrm{mg} / \mathrm{l}]=.274 \mathrm{E}-01$

Year 76.0 avg. conc. $[\mathrm{mg} / \mathrm{l}]=.259 \mathrm{E}-01$

Year 77.0 avg. conc. $[\mathrm{mg} /]=.245 \mathrm{E}-01$

Year 78.0 avg. conc. $[\mathrm{mg} / \mathrm{l}]=.232 \mathrm{E}-01$

Year 79.0 avg. conc. $[\mathrm{mg} / \mathrm{l}]=.219 \mathrm{E}-01$

Year 80.0 avg. conc. $[\mathrm{mg} / \mathrm{l}]=.207 \mathrm{E}-01$
Year 81.0 avg. conc. $[\mathrm{mg} /]=.196 \mathrm{E}-01$

Year 82.0 avg. conc. $[\mathrm{mg} / \mathrm{l}]=.185 \mathrm{E}-01$

Year 83.0 avg. conc. $[\mathrm{mg} / \mathrm{l}]=.175 \mathrm{E}-01$

Year 84.0 avg. conc. $[\mathrm{mg} / \mathrm{l}]=.165 \mathrm{E}-01$

Year 85.0 avg. conc. $[\mathrm{mg} /]=.156 \mathrm{E}-01$

Year 86.0 avg. conc. $[\mathrm{mg} / \mathrm{l}]=.147 \mathrm{E}-01$

Year $87.0 \mathrm{avg}$. conc. $[\mathrm{mg} /]=.139 \mathrm{E}-01$

Year 88.0 avg. conc. $[\mathrm{mg} /]=.131 \mathrm{E}-01$

Year 89.0 avg. conc. $[\mathrm{mg} / \mathrm{l}]=.124 \mathrm{E}-01$

Year 90.0 avg. conc. $[\mathrm{mg} / \mathrm{l}]=.117 \mathrm{E}-01$

Year 91.0 avg. conc. $[\mathrm{mg} / \mathrm{l}]=.110 \mathrm{E}-01$

Year 92.0 avg. conc. $[\mathrm{mg} /]]=.104 \mathrm{E}-01$

Year 93.0 avg. conc. $[\mathrm{mg} / \mathrm{l}]=.978 \mathrm{E}-02$

Year 94.0 avg. conc. $[\mathrm{mg} / \mathrm{l}]=.922 \mathrm{E}-02$

Year 95.0 avg. conc. $[\mathrm{mg} / \mathrm{l}]=.869 \mathrm{E}-02$

Year 96.0 avg. conc. $[\mathrm{mg} / \mathrm{l}]=.819 \mathrm{E}-02$

Year 97.0 avg. conc. $[\mathrm{mg} / \mathrm{l}]=.771 \mathrm{E}-02$

Year 98.0 avg. conc. $[\mathrm{mg} /]=.727 \mathrm{E}-02$

Year 99.0 avg. conc. $[\mathrm{mg} / \mathrm{l}]=.685 \mathrm{E}-02$

Year 100.0 avg. conc. $[\mathrm{mg} /]=.645 \mathrm{E}-02$

AT123D RUN COMPLETED

SimulationFinished 


\section{Fonte B - Receptor $90 \mathrm{~m}$}

AT123D Output File

Analysis for ...

Chemicals in the analysis

Lead

Number of years simulated:

100

GENERAI INPUT DATA

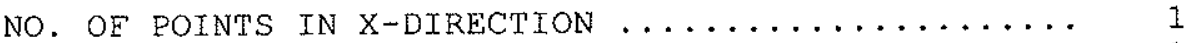

NO. OE POINTS IN Y-DIRECTION $\ldots \ldots \ldots \ldots \ldots \ldots \ldots \ldots \ldots \ldots$

NO. OF POINTS IN $Z$-DIRECTION $\ldots \ldots \ldots \ldots \ldots \ldots \ldots \ldots \ldots \ldots$

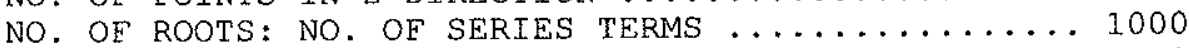

NO. OE BEGINNING TIME STEPS .............. 1

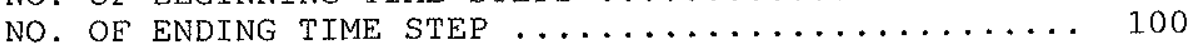

NO. OE TIME INTERVALS FOR PRINTED OUT SOLUTION .... 1

INSTANTANEOUS SOURCE CONTROL $=0$ FOR INSTANT SOURCE 0

SOURCE CONDITION CONTROL $=0$ EOR STEADY SOURCE $\ldots . .0$

INTERMITTENT OUTPUT CONTROL $=0$ NO SUCH OUTPUT $\ldots .$.

CASE CONTROL $=1$ THERMAL, $=2$ FOR CHEMICAL, $=3$ RAD 2

X-COORDINATE OF RECEPTOR WELL (METERS) ......... .9600E+02

Y-COORDINATE OE RECEPTOR WELL (METERS) .......... .0000E+00

AOUIFER DEPTH, $=0.0$ FOR INETNITE DEEP (METERS) $\ldots . .1000 E+02$

AQUIEER WIDTH $=0.0$ FOR INFINITE WIDE (METERS) $\ldots . .0000 E+00$

BEGIN POINT OF $X$-SOURCE LOCATION (METERS) ........ .0000E+00

END POINT OE $X$-SOURCE LOCATION (METERS) .......... $1190 \mathrm{\ldots}+02$

BEGIN POINT OF Y-SOURCE LOCATION (METERS) ......... .0000E+00

END POINT OF Y-SOURCE LOCATION (METERS) ......... .8100E+01

BEGIN POINT OE Z-SOURCE LOCATION (METERS) ........ .0000E+00

END POINT OF $2-$ SOURCE LOCATION (METERS) ......... . 1200E+01

POROSTTY ........................ . $1800 \mathrm{E}+00$

HYDRAULIC CONDUCTIVITY (METER/YEAR) .......... .9800E+01

HYDRAULIC GRADIENT ................... .4000E-01

LONGITUDINAL DISPERSIVITY (METER) ............. .9000E+01

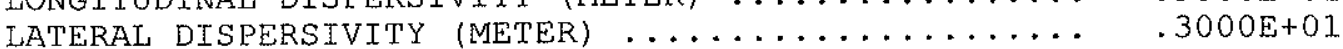

VERTICAL DISPERSIVITY (METER) .............. .4500E+00

BULK DENSITY OF THE SOIL $(K G / M * * 3) \ldots \ldots \ldots \ldots \ldots \ldots . .1800 E+04$ TIME INTERVAL SIZE FOR THE DESIRED SOLUTION (YR) .. . . $1000 E+01$ DISCHARGE TIME (YR) ................... . 0000E+00

INPUT DATA/RESULTS FOR CHEMICAL: Lead

INST. WASTE RELEASE (KG) VALID FOR INST CASE ONLY.. DISTRIBUTION COEFEICIENT, KD $\left(M^{*} * 3 / K G\right) \ldots \ldots \ldots \ldots$ MOLECULAR DIFFUSION COEEEICIENT (M**2/YR)

$.1250 \mathrm{E}+01$ $.0000 E+00$ $.0000 \mathrm{E}+00$

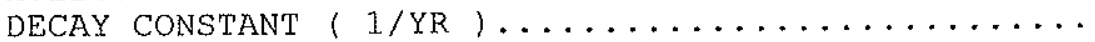
$.0000 \mathrm{E}+00$

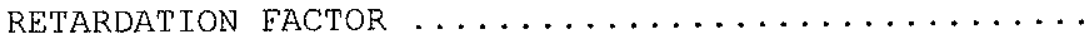
$.1000 \mathrm{E}+01$ RETARDED SEEPAGE VELOCITY (M/YR) ........... RETARDED LONGITUDINAL DISPERSION COEF. (M**2/YR) . $2178 \mathrm{E}+01$ $.1960 \mathrm{E}+02$ $.6533 \mathrm{E}+01$ RETARDED LATERAL DISPERSION COEEFICIENT $(M * * 2 / Y R)$. $.9800 \mathrm{E}+00$ 
Exemplo de Saida de Dados com Concentrações Médias no Eixo Z - Receptor Fonte B - Receptor $90 \mathrm{~m}$ (Período entre 10 e 20 anos)

time $[\mathrm{yr}]=10.0$

$\begin{array}{lll}\mathrm{z}[\mathrm{m}]=.00 \mathrm{E}+00 & \text { conc }[\mathrm{mg} / 1]=.101 \mathrm{E}-02 \\ \mathrm{z}[\mathrm{m}]=.22 \mathrm{E}+00 & \text { conc }[\mathrm{mg} / \mathrm{l}]=.101 \mathrm{E}-02 \\ \mathrm{z}[\mathrm{m}]=.44 \mathrm{E}+00 & \text { conc }[\mathrm{mg} / 1]=.100 \mathrm{E}-02 \\ \mathrm{z}[\mathrm{m}]=.67 \mathrm{E}+00 & \text { conc }[\mathrm{mg} / 1]=.995 \mathrm{E}-03 \\ \mathrm{z}[\mathrm{m}]=.89 \mathrm{E}+00 & \text { conc }[\mathrm{mg} / 1]=.985 \mathrm{E}-03 \\ \mathrm{z}[\mathrm{m}]=.11 \mathrm{E}+01 & \text { conc }[\mathrm{mg} / 1]=.973 \mathrm{E}-03 \\ \mathrm{z}[\mathrm{m}]=.13 \mathrm{E}+01 & \text { conc }[\mathrm{mg} / 1]=.959 \mathrm{E}-03 \\ \mathrm{z}[\mathrm{m}]=.16 \mathrm{E}+01 & \text { conc }[\mathrm{mg} / 1]=.942 \mathrm{E}-03 \\ \mathrm{z}[\mathrm{m}]=.18 \mathrm{E}+01 & \text { conc }[\mathrm{mg} / 1]=.923 \mathrm{E}-03 \\ \mathrm{z}[\mathrm{m}]=.20 \mathrm{E}+01 & \text { conc }[\mathrm{mg} / 1]=.902 \mathrm{E}-03\end{array}$

avg. conc. $[\mathrm{mg} / 1]=.969 \mathrm{E}-03$

time $[y r]=15.0$

$\begin{array}{lll}\mathrm{z}[\mathrm{m}]=.00 \mathrm{E}+00 & \text { conc }[\mathrm{mg} / 1]=.208 \mathrm{E}-01 \\ \mathrm{z}[\mathrm{m}]=.22 \mathrm{E}+00 & \text { conc }[\mathrm{mg} / 1]=.208 \mathrm{E}-01 \\ \mathrm{z}[\mathrm{m}]=.44 \mathrm{E}+00 & \text { conc }[\mathrm{mg} / 1]=.207 \mathrm{E}-01 \\ \mathrm{z}[\mathrm{m}]=.67 \mathrm{E}+00 & \text { conc }[\mathrm{mg} / 1]=.206 \mathrm{E}-01 \\ \mathrm{z}[\mathrm{m}]=.89 \mathrm{E}+00 & \text { conc }[\mathrm{mg} / 1]=.205 \mathrm{E}-01 \\ \mathrm{z}[\mathrm{m}]=.11 \mathrm{E}+01 & \text { conc }[\mathrm{mg} / 1]=.204 \mathrm{E}-01 \\ \mathrm{z}[\mathrm{m}]=.13 \mathrm{E}+01 & \text { conc }[\mathrm{mg} / 1]=.202 \mathrm{E}-01 \\ \mathrm{z}[\mathrm{m}]=.16 \mathrm{E}+01 & \text { conc }[\mathrm{mg} / 1]=.199 \mathrm{E}-01 \\ \mathrm{z}[\mathrm{m}]=.18 \mathrm{E}+01 & \text { conc }[\mathrm{mg} / 1]=.197 \mathrm{E}-01 \\ \mathrm{z}[\mathrm{m}]=.20 \mathrm{E}+01 & \text { conc }[\mathrm{mg} / 1]=.194 \mathrm{E}-01\end{array}$

avg. conc. $[\mathrm{mg} / 1]=.203 \mathrm{E}-01$

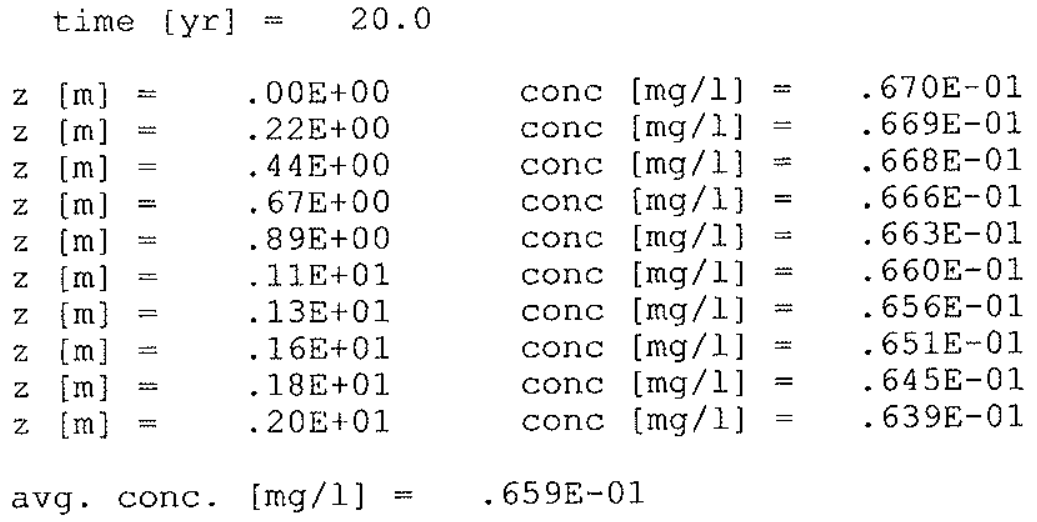

OBS: O modelo mostra esta configuração com a primeira estimativa com um ano e a partir do quinto ano a cada cinco anos. 


\section{ANEXO 04}

Estimativas de Riscos 
Estimativa de Risco / Eonte A - Receptor $70 \mathrm{~m}$ Rota de Exposição: Agua Subterrânea Receptor: Criança

Dados de Exposição: Usual

Chemicals in the analysis: Lead

Chemical Intake Analysis

Deterministic Run

$\begin{array}{lcc}\text { PARAMETER NAME } & \text { UNITS } & \text { VALUE } \\ & & \\ \text { Body Weight } & \mathrm{kg} & .150 \mathrm{E}+02 \\ \text { Life Time } & \mathrm{yr} & .640 \mathrm{E}+02 \\ \text { Exposure Duration Groundwater } & \mathrm{yr} & .600 \mathrm{E}+01 \\ \text { Exposure Frequency Ingestion } & \mathrm{dy} / \mathrm{yr} & .350 \mathrm{E}+03 \\ \text { Water Ingestion Rate } & 1 / \mathrm{day} & .100 \mathrm{E}+01 \\ \text { Exposure Frequency Shower } & \mathrm{dy} / \mathrm{yr} & .350 \mathrm{E}+03 \\ \text { Shower Duration } & \mathrm{hr} & .120 \mathrm{E}+00 \\ \text { Total Skin Surface Area } & \mathrm{Cm}^{\wedge} 2 & .950 \mathrm{E}+04\end{array}$

Lead

PARAMETER NAME

UNITS VALUE

Exposure Duration Shower Permeability Coefficient Oral Slope Factor

Oral Reference Dose

Dermal slope Factor

Dermal Reference Dose

$\begin{array}{rr}\mathrm{yr} & .100 \mathrm{E}+01 \\ \mathrm{~cm} / \mathrm{hr} & .400 \mathrm{E}-05 \\ \mathrm{~kg}-\mathrm{dy} / \mathrm{mg} & -.100 \mathrm{E}+01 \\ \mathrm{mg} / \mathrm{kg}=\mathrm{dy} & .360 \mathrm{E}-02 \\ \mathrm{~kg}-\mathrm{dy} / \mathrm{mg} & -.100 \mathrm{E}+01 \\ \mathrm{mg} / \mathrm{kg}-\mathrm{dy} & .360 \mathrm{E}-02\end{array}$

SUMMARY OF THE OUTPUTS

$* * * * * * * * * * * * * * * * * * * * * *$

NOTE: A negative RfD, SF, risk, HQ, indicates that RfD or SE was not input -- a dummy negative value was used.

DRINKING WATER

$\begin{array}{cccccc}\text { Daily Intake } & \begin{array}{c}\text { Chronic Daily } \\ \text { Intake }\end{array} & \begin{array}{c}\text { Life Av } \\ \text { Daily Dose } \\ (\mathrm{mg} / \mathrm{kg}-\mathrm{dy})\end{array} & \begin{array}{c}\text { Rg } / \mathrm{kg}-\mathrm{dy}) \\ (\mathrm{mg} / \mathrm{kg}-\mathrm{dy})\end{array}(-) & \begin{array}{c}\text { Hazard } \\ \text { Quotient } \\ (-)\end{array} \\ \text { Lead } & .105 \mathrm{E}-01 & .100 \mathrm{E}-01 & .940 \mathrm{E}-03 & -.940 \mathrm{E}-03 & .279 \mathrm{E}+01\end{array}$

DERMAL INTAKE DURING SHOWER

\begin{tabular}{|c|c|c|c|c|c|}
\hline & $\begin{array}{l}\text { Daily Intake } \\
(\mathrm{mg} / \mathrm{kg}-\mathrm{dy})\end{array}$ & $\begin{array}{c}\text { Chronic Daily } \\
\text { Intake } \\
(\mathrm{mg} / \mathrm{kg}-\mathrm{dy})\end{array}$ & $\begin{array}{l}\text { Life Av } \\
\text { Daily Dose } \\
(\mathrm{mg} / \mathrm{kg}-\mathrm{dy})\end{array}$ & $\begin{array}{c}\text { Risk } \\
(-)\end{array}$ & $\begin{array}{l}\text { Hazard } \\
\text { Quotient } \\
\qquad(-)\end{array}$ \\
\hline $\begin{array}{l}\text { Lead } \\
\text { Lea }\end{array}$ & $.477 \mathrm{E}-07$ & $.457 \mathrm{E}-07$ & $.429 \mathrm{E}-08$ & $.42 .9 \mathrm{E}-08$ & $.127 \mathrm{E}-04$ \\
\hline
\end{tabular}


Estimativa de Risco / Fonte B - Receptor $90 \mathrm{~m}$ Rota de Exposição: Água Subterrânea Receptor: Adulto Dados de Exposição: Conservador

Chemicals in the analysis: Lead

Chemical Intake Analysis

Deterministic Run

$\begin{array}{lcc}\text { PARAMETER NAME } & \text { UNITS } & \text { VALUE } \\ & \mathrm{kg} & .600 \mathrm{E}+02 \\ \text { Body Weight } & \mathrm{yr} & .640 \mathrm{E}+02 \\ \text { Life Time } & \mathrm{yr} & .300 \mathrm{E}+02 \\ \text { Exposure Duration Groundwater } & .365 \mathrm{E}+03 \\ \text { Exposure Frequency Ingestion } & \mathrm{dy} / \mathrm{yr} & .200 \mathrm{E}+01 \\ \text { Water Ingestion Rate } & 1 / \mathrm{day} & .36 \mathrm{E}+03 \\ \text { Exposure Erequency Shower } & \mathrm{dy} / \mathrm{yr} & .365 \mathrm{E} \\ \text { Shower Duration } & \mathrm{hr} & .333 \mathrm{E}+00 \\ \text { Total Skin Surface Area } & \mathrm{cm}^{\wedge} 2 & .166 \mathrm{E}+05\end{array}$

\section{Lead}

PARAMETER NAME UNITS VALUE

Exposure Duration Shower permeability Coefficient Oral Slope Factor Oral Reference Dose Dermal Slope Factor Dermal Reference Dose

$\begin{array}{rr}y r & .100 E+01 \\ \mathrm{~cm} / \mathrm{hr} & .400 \mathrm{E}-05 \\ \mathrm{~kg}-\mathrm{dy} / \mathrm{mg} & -.100 \mathrm{E}+01 \\ \mathrm{mg} / \mathrm{kg}-\mathrm{dy} & .360 \mathrm{E}-02 \\ \mathrm{~kg}-\mathrm{dy} / \mathrm{mg} & -.100 \mathrm{E}+01 \\ \mathrm{mg} / \mathrm{kg}-\mathrm{dy} & .360 \mathrm{E}-02\end{array}$

SUMMARY OF THE OUTPUTS

$* * * * * * * * * * * * * * * * * * * * * *$

NOTE: A negative RfD, SE, risk, HQ, indicates that RfD or SF was not input -- a dummy negative value was used.

DRINKING WATER

$\begin{array}{lrcccc}\text { Daily Intake } & \begin{array}{c}\text { Chronic Daily } \\ \text { Intake } \\ (\mathrm{mg} / \mathrm{kg}-\mathrm{dy})\end{array} & \begin{array}{c}\text { Life Av } \\ \text { Daily Dose } \\ (\mathrm{mg} / \mathrm{kg}-\mathrm{dy})\end{array} & \begin{array}{c}\text { Razard } \\ (\mathrm{mg} / \mathrm{ky})\end{array}(-) & \begin{array}{c}\text { Quotient } \\ (-)\end{array} \\ \text { Lead } & .390 \mathrm{E}-02 & .390 \mathrm{E}-02 & .183 \mathrm{E}-02 & -.183 \mathrm{E}-02 & .108 \mathrm{E}+01\end{array}$

DERMAL INTAKE DURING SHOWER

$\begin{array}{cccccc}\text { Daily Intake } & \begin{array}{c}\text { Chronic Daily } \\ \text { Intake } \\ (\mathrm{mg} / \mathrm{kg}-\mathrm{dy})\end{array} & \begin{array}{c}\text { Life Av } \\ \text { Daily Dose } / \mathrm{kg}-\mathrm{dy}) \\ (\mathrm{mg} / \mathrm{kg}-\mathrm{dy})\end{array}(-) & \begin{array}{c}\text { Razard } \\ \text { Quotient } \\ (-)\end{array} \\ \text { Lead } & .432 \mathrm{E}-07 & .432 \mathrm{E}-07 & .202 \mathrm{E}-07 & -.202 \mathrm{E}-07 & .120 \mathrm{E}-04\end{array}$


Estimativa de Risco / Fonte B - Receptor 90 m

Rota de Exposição: Água Subterrânea Receptor: Criança

Dados de Exposição: Usual

Chemicals in the analysis: Lead

Chemical Intake Analysis

Deterministic Run

$\begin{array}{lcc}\text { PARAMETER NAME } & \text { UNITS } & \text { VALUE } \\ & & \\ \text { Body Weight } & \mathrm{kg} & .150 \mathrm{E}+02 \\ \text { Life Time } & \mathrm{yr} & .640 \mathrm{E}+02 \\ \text { Exposure Duration Groundwater } & \mathrm{yr} & .600 \mathrm{E}+01 \\ \text { Exposure Frequency Ingestion } & \mathrm{dy} / \mathrm{yr} & .350 \mathrm{E}+03 \\ \text { Water Ingestion Rate } & 1 / \mathrm{day} & .100 \mathrm{E}+01 \\ \text { Exposure Erequency Shower } & \mathrm{dy} / \mathrm{yr} & .350 \mathrm{E}+03 \\ \text { Shower Duration } & \mathrm{hr} & .120 \mathrm{E}+00 \\ \text { Total Skin Surface Area } & \mathrm{cm}^{\wedge} 2 & .950 \mathrm{E}+04\end{array}$

Lead

PARAMETER NAME

UNITS VALUE

Exposure Duration Shower Permeability Coefficient

Oral Slope Factor

Oral Reference Dose

Dermal Slope Eactor

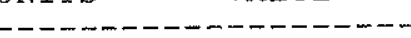

Dermal Reference Dose

$\begin{array}{rr}\mathrm{yr} & .100 \mathrm{E}+01 \\ \mathrm{~cm} / \mathrm{hr} & .400 \mathrm{E}-05 \\ \mathrm{~kg}-\mathrm{dy} / \mathrm{mg} & -.100 \mathrm{E}+01 \\ \mathrm{mg} / \mathrm{kg}-\mathrm{dy} & .360 \mathrm{E}-02 \\ \mathrm{~kg}-\mathrm{dy} / \mathrm{mg} & -.100 \mathrm{E}+01 \\ \mathrm{mg} / \mathrm{kg}-\mathrm{dy} & .360 \mathrm{E}-02\end{array}$

SUMMARY OF THE OUTPUTS

$* * * * * * * * * * * * * * * * * * * * * *$

NOTE: A negative RfD, SF, risk, HQ, indicates that RfD or SF was not input -- a dummy negative value was used.

DRINKING WATER

$\begin{array}{cccccc}\text { Daily Intake } & \begin{array}{c}\text { Chronic Daily } \\ \text { Intake } \\ (\mathrm{mg} / \mathrm{kg}-\mathrm{dy})\end{array} & \begin{array}{c}\text { Life Av } \\ \text { Daily Dose } \\ (\mathrm{mg} / \mathrm{kg}-\mathrm{kg})\end{array}(-) & \begin{array}{c}\text { Hazard } \\ \text { Quotient } \\ (-)\end{array} \\ \text { Lead } & .903 \mathrm{E}-02 & .866 \mathrm{E}-02 & .812 \mathrm{E}-03 & -.812 \mathrm{E}-03 & .241 \mathrm{E}+01\end{array}$

DERMAL INTAKE DURING SHOWER

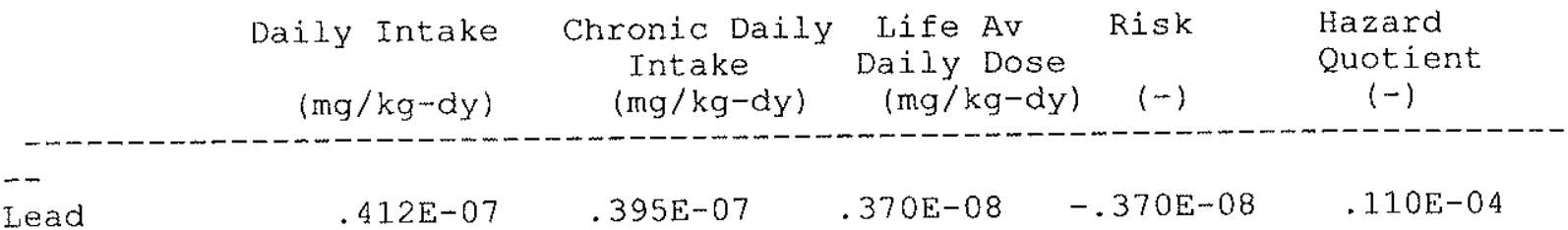




\section{REFERÊNCIAS BIBLIOGRÁFICAS}

ABNT - ASSOCIAÇÃO BRASILEIRA DE NORMAS TÉCNICAS (1997) - Construção de Poços de Monitoramento e Amostragem - NBR 13895. Rio de Janeiro, 21 p. APPELO, C. A. J. \& POSTMA, D. (1994) - Geochemistry, Groundwater and Pollution. A. A. Balkema Rotterdam / Brookfield, 536p.

API - AMERICAN PETROLEUM INSTITUTE (1994) - Decision Support System for Exposure and Risk Assesment - Version 1.0.

ASTM - AMERICAN SOCIETY FOR TESTING AND MATERIALS (1996) - Standard Guide for Planning and Preparing for a Groundwater Sampling Event. EUA. ASTM Designation D 5903-96, 4 .

ASTM - AMERICAN SOCIETY FOR TESTING AND MATERIALS (1998) - Standard

Provisional Guide for Risk-Based Corrective Action. EUA. ASTM Designation PS 104-98, $100 p$.

ATSDR - AGENCY FOR TOXIC SUBSTANCES AND DISEASE REGISTRY (1993) -

Toxicological Profile for Lead. Atlanta: U.S. Department of Health and Human Services, Public Health Service (www. atsdr.cdc.gov/mrls.html).

BERNARDES JÚNIOR, C. (1995) - Avaliação de Risco de Longo Prazo, em Casos de Contaminação de Águas Subterrâneas como Instrumento de Gerenciamento da Remediação. Tese de Doutoramento - Instituto de Geociências da Universidade de São Paulo - SP, $192 p$.

BRITISH COLUMBIA ENVIRONMENT (1993) - Quantitative Human Health Risk Assessment: Phase 01 - Review of Methods and Framework Recommendation.

BROOKINS, D. G. (1988) - Eh - pH Diagrams for Geochemistry. Springer-Verlag Berlin Heidelberg New York, $176 p$. 
CETESB - COMPANHIA DE TECNOLOGIA DE SANEAMENTO AMBIENTAL DO ESTADO DE SÃO PAULO (1988) - Guia de Coleta e Preservação de Amostras de Água. São Paulo, 150 p.

CETESB - COMPANHIA DE TECNOLOGIA DE SANEAMENTO AMBIENTAL DO ESTADO DE SÃO PAULO (1990) - Compilação de Padrões Ambientais. São Paulo, $6 \mathrm{p}$.

CETESB - COMPANHIA DE TECNOLOGIA DE SANEAMENTO AMBIENTAL DO ESTADO DE SÃO PAULO (1995) - Legislação Federal - Controle de Poluição Ambiental. Série Documentos, São Paulo, 213 p.

CETESB - COMPANHIA DE TECNOLOGIA DE SANEAMENTO AMBIENTAL DO ESTADO DE SÃO PAULO (1999) - Relatório de Qualidade das Águas Interiores do Estado de São Paulo. Série Relatórios Ambientais, São Paulo, $391 p$.

CETESB - COMPANHIA DE TECNOLOGIA DE SANEAMENTO AMBIENTAL DO ESTADO DE SÃO PAULO (1999) - Legislação Estadual - Controle de Poluição Ambiental. Série Documentos. São Paulo, 498 p.

CETESB - COMPANHIA DE TECNOLOGIA DE SANEAMENTO AMBIENTAL DO ESTADO DE SÃO PAULO (2000) - Estabelecimento de Valores de Referência de Qualidade e Intervenção para Solos e Agua Subterrânea no Estado de São Paulo. São Paulo, 92 p.

CETESB - COMPANHIA DE TECNOLOGIA DE SANEAMENTO AMBIENTAL DO ESTADO DE SÃO PAULO (2001) - Estabelecimento de Valores Orientadores para Solos e Água Subterrânea no Estado de São Paulo. Tabela Final Revisada (Relatório Final, no prelo). São Paulo, $1 p$.

CORSEUIL, H. X. (1999) - Atenuação Natural de Metais em Água Subterrânea. Apostila de Curso, $12 p$.

CPRM - SERVIÇO GEOLOGICO DO BRASIL (1997) - Hidrogeologia : Conceitos e Aplicações. Fortaleza : CPRM, LABHID-UFPE, $412 p$. 
CUNHA, R. C. A. (1997) - Avaliação de Risco em Areas Contaminadas por Fontes Industriais Desativadas - Estudo de Caso. Tese de Doutoramento - Instituto de Geociências da Universidade de São Paulo - SP, $152 p$.

DEUTSCH, W. J (1997) - Groundwater Geochemistry - Fundamentals and Applications to Contamination. Lewis Publishers - Boca Taton / New York, 221 p.

DOMENICO, P. A. \& SCHWARTZ, F. W. (1998) - Physical and Chemical Hydrology. John Wiley \& Sons, New York, 506p.

FETTER, C. W. (1988) - Applied Hydrogeology. Merrill Publishing Company, Columbus, Ohio. $592 p$.

FETTER, C. W. (1993) - Contaminant Hydrogeology. Macmillan Publishing Company, New York, New York. 458 p.

FETTER, C. W. (1994) - Applied Hydrogeology. Merrill Publishing Company, Upper Saddle River, New Jersey. 691 p.

FETTER, C. W. (1999) - Contaminant Hydrogeology. Prentice Hall, Inc., Upper Saddle River, New Jersey. 500 p.

FREEZE, R. A. e CHERRY, J. A (1979) - Groundwater. Prentice Hall, Inc. New Jersey. $604 p$.

FINOTTI, A. R. (1997) - Estudo da Aplicabilidade do Modelo da Ação Corretiva Baseada no Risco (RBCA) em Contaminações Subterrâneas com Gasolina e Etanol. Dissertação de Mestrado - Universidade Federal de Santa Catarina, $113 p$.

HARTE, J. et al (1991) - Toxics A to Z Guide to Everyday Pollution Hazards. University of Califórnia Press, $479 p$.

MINISTÉRIO DA SAÚDE (2000) - Portaria 1469. Brasil, $17 p$.

PALMER, C. M. (1996) - Principles of Contaminant Hydrogeology. Lewis Publishers, New York, $235 p$. 
PENALOZA, A. (2001) - Avaliação do Impacto causado na Zona Saturada pelos Metais Pesados provenientes da Disposição de Lodo Residual na ETE de Barueri - SP. Dissertação de Mestrado - Instituto de Geociências da Universidade de São Paulo - SP, $90 p$.

SABESP - COMPANHIA DE SANEAMENTO BÁSICO DO ESTADO DE SÃO PAULO (1997) - Programa Consenvação do Sistema Cotia. Relatório Interno (Tomo l) Avaliação Ambiental. SABESP / Fundação Brasileira para o Desenvolvimento Sustentável, São Paulo.

SMA - SECRETARIA DE ESTADO DE MEIO AMBIENTE: IG - INSTITUTO GEOLOGICO; CETESB - COMPANHIA DE TECNOLOGIA DE SANEAMENTO AMBIENTAL; DAEE - DEPARTAMENTO DE AGUAS E ENERGIA ELÉTRICA (1997) - Mapeamento da Vulnerabilidade e Risco de Poluição das Águas Subterrâneas no Estado de São Paulo. Série Documentos. Volumes I e II. 129 $p$.

SRACEK, A. (1998) - Aspectos Fenomenologicos e Hidrogeoquimicos en Contaminacion Ambiental. Universidad Catolica del Norte, Chile - Apostila de Curso.

USEPA - UNITED STATES ENVIRONMENTAL PROTECTION AGENCY / IRIS INTEGRATED RISK INFORMATION SYSTEM (2001) - Compounds (last revised): Copper (1991); Lead (1993) and Zinc (1992)(http://www.epa.gov/iris)

YEH, G. T. 1981 -AT123D : Analytical Transient One, Two and Three Dimensional Simulation of Waste Transport in the Aquifer System. Oak Ridge National Laboratory, Oak Ridge, TN. 